\title{
Davao: \\ A Case Study in \\ Japanese-Philippine Relations
}

\author{
Grant K. Goodman
}

International Studies, East Asian Series

Research Publication, Number One

Center for East Asian Studies

The UNIVERSITY OF Kansas 


\section{Davao: \\ A Case Study in \\ Japanese-Philippine Relations}

Grant K. Goodman

International Studies, East Asian Series

Research Publication, Number One

Center for East Asian Studies

The University of Kansas 
Copyright (C) 1967 by Grant K. Goodman

Library of Congress catalog card number: $67-65570$

All rights reserved

Manufactured in the United States of America 


\section{Editor's Preface}

The publication of this volume marks the first Research Publication from the Center for East Asian Studies. The Center hopes to continue publishing studies, whether by its own staff members or others, which, as Professor Goodman's monograph does, explore significant problems in the field of East Asian Studies.

A Reference Publication Series is also planned, the first volume of which, $A$ Chinese-English Dictionary for Students by C. C. Huang, is under preparation.

EDGAR WickBerg

EDITOR 


\section{Contents}

Introduction .................................................................. vii

The Japanese Settlement in Davio:

Origins and Development .............................................. 1

The Alunan Report and the Free Press 'Letter' ............... 11

Investigations of Davao: American and Philippine ......... 19

Davao: A Continuing Japanese Success Story .................... 25

The Philippine Constitutional Convention and Davao .. 32

Secretary Rodriguez Enters the Picture .......................... 39

Japanese Countermeasures ............................................. 46

Rodriguez Undaunted but not Unopposed ....................... 53

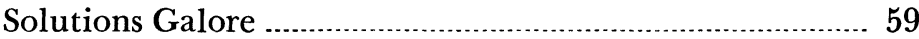

Quezon Takes Charge …............................................... 65

Davao: On an Even Keel …............................................ 77

The Alexander Resolution ............................................. 86

Danger Ahead: Provincial Politics _................................ 96

A Solution Achieved ….............................................. 98

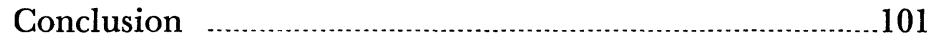

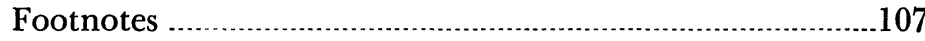




\section{Introduction}

Before World War II, the largest concentration of overseas Japanese migrants in Southeast Asia was in the Davao region in the Philippines. Similarly, the most significant Japanese economic ventures anywhere in Southeast Asia were also concentrated in the area around Davao. Remarkably, both developments had occurred in a relatively brief period of time, i.e., in less than four decades. Both the scope of the Japanese settlement at Davao and the speed with which it had grown were a tribute to the ingenuity and perseverance of the Japanese settlers as well as to the entrepreneurial leadership of a small nucleus of canny and determined Japanese adventurer-businessmen.

While the Davao colony itself has been described in a number of sources, what this study seeks to do is to place the Davao story in the overall context of Japanese-Philippine relations. By principal reliance on the archives of the Japanese Ministry of Foreign Affairs, on the records of the American Bureau of Insular Affairs, and on the personal papers of Manuel L. Quezon, it is hoped that a more complete picture can be drawn of the many conflicting interests concerned with the Davao settlement. For here at Davao was a microcosm not only of Japanese-American relations but, also, perhaps more importantly, of the relations between an increasingly aggressive imperial Japan and a soon-to-be independent Philippines.

It is, in fact, to this latter issue that the pages which follow are primarily devoted, and it is for this reason that the title refers to a "case study" in Japanese-Philippine relations. For in one or another respect, all of the factors-economic, political, militarywhich affected the contacts between Japan and the Philippines during the American colonial period were highlighted in the Davao situation. Moreover, of special importance to the presentation that follows is an understanding of this writer's hypothesis that during the period of American hegemony in the Islands, relations between Japan and the Philippines were basically good and were in fact getting better even as World War II began. The contention is that what from time to time proved detrimental 
to Japanese-Philippine relations and what, of course, eventually brought them to a nadir were the tensions and strains in Japanese-American relations.

In recent days many have been critical of the diplomats of the new nations of Asia, Africa, or the Middle East. Many scholars of Japanese politics have been equally critical of the record of Japan's diplomacy in the years before World War II. However, these critics might do well to reexamine their conclusions and recognize that at least in the instance of JapanesePhilippine relations, Japan's diplomatic efforts were prudent, cautious, and generally successful, while, for their part, Filipino officials, despite their lack of any real authority since the Philippines were still under American control, handled affairs with Japan with marked restraint and considerable acumen.

Indeed, the record on both sides is particularly impressive when one considers the inflamed atmosphere that generally enveloped international affairs, especially after 1931. For there is no question that the focus of Japanese interest in Davao bore within it the seeds of potentially serious conflict between Japan and the Philippines. Yet, the restraint exercised by both Japanese consular officials in the Islands and by members of the Filipino ruling elite maintained a relative equilibrium between the two states. To be sure, there were recurrent irritants which temporarily ruffled the course of Japanese-Philippine relations, and many of these are recounted in this monograph. Nevertheless, the consistently overriding consideration for both parties was the recognition of the mutuality of economic benefits derived from the Japanese development of Davao.

However, as expanding Japanese interests in Southeast Asia seemed to confront Philippine aspirations for independence, increasing attention was directed at Japan's involvement in Davao. The American authorities, in particular, viewed the Davao region with growing concern but were generally careful to do nothing which could be interpreted, even indirectly, as inimical to Japanese interests. Moreover, the diplomatic efforts of the leaders of the Philippines were primarily devoted to the relaxation of Japanese-Philippine tensions, and Japanese repre- 
sentatives in the Islands responded in kind. Therefore, in late 1941, on the eve of World War II, the ultimate resolution of the Davao problem through behind-the-scenes negotiations between the Japanese Consulate General and the Philippine Commonwealth executive indicated the extent of both sides' mutual commitment to achieving a modus vivendi.

Perhaps what is crucial to the historian of these events is that nothing in the record of Japanese-Philippine relations as exemplified in this case study of Davao can be described as having contributed to the outbreak of Japanese-American hostilities in the Pacific. No evidence whatever exists to prove, as so many suggested, especially in the decade after 1931, that the Japanese colony at Davao was in any way a bridgehead for the ultimate seizure of the Philippines. At no time was Davao anything more than an outstanding example of what could be accomplished by the application of Japanese energy and ingenuity to an otherwise somnolent and unproductive tropical area. Moreover, the Filipinos were neither frightened by nor overly concerned about the growth of Japanese economic interest in Davao. On the contrary, most Philippine leaders, though unable to air their views publicly owing to the continued American presence in the Islands, welcomed the Japanese contribution to the development of the Commonwealth. And, as the record demonstrates, many of these same Filipinos were in fact closely connected either politically or economically or both with Japanese activities at Davao.

That Japanese diplomats and businessmen were able to ingratiate themselves with key Filipinos and were able to use these contacts to further their success in the Islands can hardly be considered a triumph of deviousness. Rather, these Japanese deserve full credit for the speed with which they learned to operate within a Philippine context and for the tact and skill by means of which they achieved acceptance by Filipinos. The full extent of Japanese success in this regard became clearly evident during the World War II occupation of the Islands when the Japanese, as occupiers, were able to call upon so many key members of the Filipino elite to serve in the occupation regime under 
Japanese supervision. And those Filipinos who served did so not because they were either "unpatriotic" or "patriotic" but because of the personal relations that had developed before the war between themselves and many Japanese whom they knew, trusted and, most importantly in their view, liked. 


\section{The Japanese Settlement in Davao: \\ Origins and Development}

The heart of the Japanese colony in the Philippines was the province and city of Davao ${ }^{1}$ on the island of Mindanao. ${ }^{2}$ Japanese settlement in the Davao area had developed as a result of the coincidence of three factors: the need of the abaca (hemp) plantation owners ${ }^{3}$ for hardy and industrious laborers, ${ }^{4}$ the presence in the Philippines of unemployed Japanese who had originally been brought to the Islands by the American builders of the Benguet or Kennon zigzag road to Baguio in Mountain Province in Central Luzon, and the foresighted enterprise of K. S. Ohta (Ota Kyosaburo).

Ohta (1876-1917) was a Kobe merchant who had come to Manila at the turn of the century with a profound belief in the future of Japanese-Philippine trade and who had made his mark both with the American authorities and his fellow Japanese by quelling discontent among the Baguio road gang through his provision of sorely missed Japanese necessities. It was logical, therefore, for Ohta to act as a kind of go-between or labor contractor for the labor-seeking plantation owners and the jobseeking Japanese, and with the encouragement of the insular government to arrange the importation of these laborers into Davao in 1904 and $1905 .^{5}$ In 1905 , Ohta himself settled permanently in Davao, where he opened a general store catering to his Japanese clientele, ${ }^{6}$ and here Ohta became a kind of father confessor to the homesick laborers and eventually unofficial leader of the Japanese community.

At the outset the migration of Japanese laborers to Davao seems to have been motivated by the same purely economic stimulus which attracted them to work on the Baguio road. There is no evidence that any significant number of these men had thought of remaining permanently at Davao. Rather, they planned to return to Japan, taking with them their hard-earned savings. But the real agricultural potentialities of the broad undeveloped Davao region quickly became apparent to many of the laborers, almost all of whom were themselves of peasant 
origin. The soil was fertile and was kept moist by a consistent and well distributed annual rainfall draining onto a watershed sloping from Mount Apo, the highest peak in the Philippines at 9,610 feet, to the seacoast. Moreover, the relatively mild and typhoon-free climate with its continuous growing season made life in Davao not dissimilar to life in Okinawa or in Kyushu or western Honshu, from which places most of the Japanese came. A further impetus to Japanese colonization resulted from the failure of most of the American ex-soldier planters to secure the necessary capital or to have the technical skill needed to pioneer in these newly opened lands. The rigors and hazards of tropical living, the loneliness and remoteness of Davao, and the general problems of adjusting to totally alien surroundings combined to contribute to an early exodus for all but a few of these American settlers.

Thus, in 1906, with most of the Americans departed but the land's potentialities still evident, Ohta decided to develop an abaca plantation of his own by acquiring land from the aboriginal Bagobo tribe. However, Ohta was called in by Governor Allen Walker of the Davao District and informed that since tribal lands were classified as public lands, and since, under the Philippines Act of 1902, alien individuals could not acquire public lands, Ohta was illegally occupying public lands, and that if he did not evacuate those lands, court proceedings would be instituted. ${ }^{7}$ Ohta agreed to give up these lands within six months, though he could not have been compelled to do so without a suit being entered in court against him.

However, having determined upon a policy of land acquisition, Ohta was not to be deterred, and he soon found the answer to his dilemma in the Public Land Act (Act No. 926) of 1903, which permitted any legally organized corporation to purchase or lease agricultural land in the public domain up to a maximum of 1,024 hectares (one hectare $=2.471$ acres), leases being for twenty-five years and renewable for an additional 25 years. $^{8}$ When in May of 1907, Ohta established the Ohta Development Company with himself as majority stockholder, he invited investments from his compatriots, and a few of the laborers, very 
wisely as events were to prove, put into Ohta's corporation the funds they had been saving for their return to Japan. ${ }^{9}$ Thus, the foundation of the Ohta Development Company and the Philippine government's awarding it 1,015 hectares of public land for which it applied marked the beginning of a new era in the situation of the Japanese at Davao.

Japanese were now landholders and land developers in their own right, and permanent colonization rather than transient residence became characteristic of the Japanese population of Davao. And, as the lands acquired under Public Act 926 prospered, the urge to acquire additional lands grew greater, and the search on the part of the Japanese for legal loopholes by which landholdings might be expanded grew more intense. Simultaneously, the idea of resistance to the extension of the Japanese foothold at Davao became at least the private view of some officials of the American colonial administration as witness Governor Walker's fearful prediction to the Secretary of the Moro Province on November 9, 1907:

If the Japanese are allowed to secure a foothold and settle in such large numbers in one of the fairest spots and which bids fair to be one of the richest in the Moro Province and possibly in the Philippine Islands, the consequences in the future can easily be foretold. ${ }^{10}$

However, American policy was not immediately affected by such forebodings, for by 1910, the Ohta Development Company's abaca harvest led that of all other planters in the Davao area, and in 1912, Ohta opened an export branch office in Manila. ${ }^{11}$ Now that Ohta had his own land, he eagerly and rapidly introduced the most advanced methods of cultivation, fertilization, and irrigation. In addition, he encouraged experimentation not only in the growing and harvesting of abaca, but in the introduction of new and diverse agricultural products (fruits, vegetables, rubber, cotton, coffee) and even in the raising of chickens and pigs. Moreover, the success of the Ohta Development Company stimulated the investment of new capital from Japan in the Davao region and the formation of a number of other Japanese-sponsored plantation corporations. Both the 
arrival of new immigrants from Japan and the acquisition of new lands by the Japanese proceeded apace.

World War I gave further impetus to the development of the abaca industry, and the Japanese were in the forefront of the hemp boom. In 1914, for example, the Furukawa Plantation Company was founded with Furukawa Yoshizo as president; and Leopoldo Aguinaldo (1885-1958), who had himself studied textile engineering in Japan at the Polytechnical Institute of $\mathrm{Na}$ goya from 1905 to 1909 , was the only non-Japanese among the seven original incorporators. ${ }^{12}$ The Furukawa Company was subsequently to become, along with the Ohta Development Company, one of the two major Japanese concerns at Davao.

Wartime naval expansion sent prices of "Manila hemp" spiraling still higher, and land under cultivation was increased as rapidly as possible. By 1916, an estimated 10,000 Japanese were in Davao; ${ }^{13}$ and by the end of 1918 , out of 164 plantations in Davao, the Japanese owned 71, Americans 34, Filipinos 44, and other nationalities $15 .^{14}$ Approximately $60 \%$ of the cultivated land area was in Japanese holdings, which averaged 797 hectares each and which were producing hemp from 2,946 hectares and copra from 29,311 coconut trees. ${ }^{15}$

Despite the several existing legal barriers to land acquisition by aliens, therefore, the Japanese had by 1919 obviously discovered a number of extralegal devices by which additional lands might be brought under their control. These included the purchase of private lands (since no law as yet prohibited the sale of private property to aliens ${ }^{16}$ ); the subleasing for a contracted period of lands held by American, Filipino, or Spanish individuals or corporations; the organization of smaller independent corporations by larger corporations, such as Ohta and Furukawa, through which more public lands could be leased within the 1,024 hectare limitation; ${ }^{17}$ the leasing of lands obtained by Filipino government officials in the names of their wives, relatives, or friends; the purchase or lease from the Philippine National Bank of lands confiscated from defaulting Filipino or American landowners; and even "marriage" to Bagobo and Manobo 
women, who then used Japanese funds to purchase land, ${ }^{18}$ the title to which would remain in the women's hands.

In an attempt to meet this situation the Philippine Legislature, over the protests of the Japanese settlers (protests supported by the Japanese government), passed the Public Land Act of $1919,{ }^{19}$ which provided that no individual or corporation could purchase or lease land unless $61 \%$ of the capital stock was owned by a United States or Philippine citizen. While no additional lands were acquired by Japanese corporations after 1919, the effect of the new legislation on the Davao land question was much more apparent than real. In fact, claims have been made that the legislation was largely the result of pressure from the Philippine legal profession, which then played a crucial role in drafting contractual agreements by which the Japanese might evade the new act. At any rate, after 1919, the two principal means of Japanese land acquisition became the dummy corporation, whose Filipino incorporators were well paid for their "trouble," ${ }^{20}$ and the so-called pakiaw (pakiao, paquiao) system.

The latter arrangement made it appear that the Filipino landowner was in effect hiring the personal services of the Japanese. The pakiaw contract provided that the Japanese was to be employed to clear the land, to plant abaca at his own expense, and, when the abaca was two years old, to be paid one peso for every "hill" of abaca planted by him. If the landholder failed to pay the one peso per "hill," and such failure was standard procedure, the contract further provided that the Japanese was to retain possession of the land for from ten to fifteen years, during which time he would continue to clear the land, cultivate abaca, strip the fiber, and receive from 85 to $90 \%$ of the profits, the rest going to the Filipino landholder. Moreover, the Japanese cultivator was to bear all the expenses of land development and improvement and even pay the taxes. ${ }^{21}$

The effect of the 1919 legislation and especially the effects of the dummy corporation and pakiaw system on the landholding pattern in Davao may be seen in a report of the Provincial Treasurer of Davao for 1930, which lists the number of plantations owned by different nationalities. Japanese-owned plantations de- 
sociation of Davao stated that although during the Philippine political season it was customary for candidates to try to publicize themselves by hurling imprecations at the Japanese, there was no real cause for concern. Rather, it suggested, there was understanding between the Japanese and the local population, and the Filipinos welcomed the arrival of the Japanese in Davao. The same document emphasized the general harmony evident within the Japanese community as well and predicted a promising future for the area. ${ }^{31}$ Since the Japanese themselves, and most particularly the leaders of their community association, would have been the first to complain to the Japanese government about mistreatment of any kind or to report to their home government any potential threats to their interests, such an evaluation ought to be given full credence as a fair depiction of the situation of the Davao Japanese in mid-1930.

It is also worthwhile to examine some of the evidence on the official American view of the Japanese colony in Davao since, during the 1930's when the Davao question became an often inflammatory issue in Philippine politics, the charge was frequently leveled by Filipino politicians that the buildup of the Japanese concentration at Davao had taken place with not only the consent but with the encouragement of the American authorities. On September 2, 1925, Colonel Carmi A. Thompson, who had been sent to the Philippines as a special representative of President Coolidge, made a full day's inspection of Davao. Colonel Thompson met with the leaders of the Davao Japanese Association, inspected the experiment station with the hemp stripping machine of the Furukawa Plantation Company and made a brief rest stop at the Ohta Development Company. He told his Japanese hosts that he was already well acquainted with the fact that the development of Davao Province was a result of Japanese efforts. Colonel Thompson further said that he recognized that the introduction of capital investments and the application of machine power by the Japanese had made the progress in Davao possible. In summarizing the visit of this presidential emissary, the Japanese consular representative in Davao wrote, "[Colonel 
Thompson] demonstrated that he had a favorable attitude toward the developmental activities of the Japanese here."32

An equally informative insight into the attitude of a key American official was contained in a February, 1929, secret report from the Consul General in Manila to the Foreign Office concerning the attitude toward the Japanese of former Philippine Governor General Henry L. Stimson, by then the newly appointed Secretary of State. After praising Stimson's general understanding of and impartiality toward foreigners, the Consul General noted that throughout his tenure in the Islands Stimson had always demonstrated goodwill toward Japan, especially by rejecting on the grounds of international mutuality legislation seeking to restrict Japanese agricultural, fishing, and lumbering enterprises. According to the Consul General, Stimson had had only praise for the organization and orderliness of the Japanese undertakings at Davao, and he had pointed to them as examples of what Filipinos themselves might do to develop their own country. Though as Governor General, Stimson had visited Mindanao several times, he had never visited Davao. When he was asked why he had not done so, he replied that it was not necessary to inspect an area where there were no complaints. ${ }^{33}$

Nevertheless, despite the generally favorable situation in Davao itself and the broadly tolerant attitude of American officials during the 1920's, the existence of a tightly knit, well organized, capably led, and economically thriving Japanese community in the Philippines did arouse anxiety in some quarters. The attention of the Philippine government was called to the Davao "problem" on numerous occasions, especially by the press, and the plea that "something must be done" became a fairly familiar one. So vocal did some of these critics become that in 1926, a committee of officials of the Bureau of Lands headed by its Assistant Director carried out an on-the-scene investigation in Davao of the business dealings and management of all the Japanese corporations, searching for any substantiation of alleged land-law violations. After two months of intensive study of the situation, the committee reported that all the charges made were totally without foundation and that, contrary to what had 
been suggested, the Japanese, acting wholly within the law, had made great contributions to the agricultural development of Davao. $^{34}$

The results of the Bureau of Lands investigation were not unexpected in the era between the end of World War I and the Manchurian Incident, a period which saw perhaps the most unimpeded growth of the Japanese settlement in Davao. The lack of obstacles to Japan's progress was the result of several factors: diligent and thorough diplomatic activity on the part of Japan's consular representatives in both Manila and Davao; tolerant encouragement of the introduction of foreign capital into the Philippines by Governors General appointed by Republican administrations in Washington; successful lobbying by Japanese business interests among Filipino legislators and provincial officials; a desire by Filipino lawyers, dummy corporations and pakiaw "landlords" to leave undisturbed what were for them very satisfactory arrangements; the generally favorable attitude of the Bagobo tribesmen in Davao toward the Japanese, whom they preferred to the Christianized Filipinos; ${ }^{35}$ and the American-Japanese "honeymoon" era in international politics, reflected in the several Washington Treaties of 1922 and the Kellogg-Briand Pact of 1928.

In an interview published in the Manila Tribune in September, 1929, Trade Commissioner Howard of the Philippines denied once again that there was any Japanese violation of land laws in Davao or any so-called Japanese menace. On the contrary the Commissioner affirmed that there was a voluntary influx of Filipino workers into Davao, where they were assured good wages and decent living conditions on Japanese plantations. Moreover, he praised the Japanese for their having constructed at their own expense some two hundred kilometers of roads in the Davao region and for their experimentation leading to improved methods of growing and stripping abaca. Said Howard:

Davao is fast becoming the greatest hemp producing province in the Philippines, due largely to the very progressive methods and splendid organization of the Japanese planters there. ${ }^{36}$ 


\section{The Alunan Report and the Free Press 'Letter'}

The relative equilibrium and equanimity of the Japanese at Davao were seriously disturbed for the first time by the so-called Alunan Report in 1930. In April of that year Rafael Alunan, then Secretary of Agriculture and Natural Resources, made an inspection tour of the southern Philippines including Mindanao and on his return submitted to the Governor General a report which was made public May 22. In his report Alunan made a number of recommendations for policies in the area. Of particular significance to Philippine-Japanese relations was his statement that Davao appeared to be "a small Japanese colony" and his proposal that "in the light of the information obtained in my recent trip to Mindanao concerning the port of Davao, I believe that the question of closing it as a port of entry deserves some attention. . .."37 Alunan elaborated his views on the latter suggestion by noting that the opening of Davao as a port of entry had been prejudicial to the expansion of inter-island shipping, which, because it was still in its infancy, needed all possible assistance. He emphasized that if Davao had not been opened as a port of entry, "all the products that the Japanese are exporting directly to Japan would necessarily be sent to Zamboanga, Cebu or Manila and the coastwise trade would be benefited that much....."38

As might have been anticipated, swift reaction to the Alunan report came from several quarters. The Philippines Herald, which was owned by the influential shipping magnate Vicente Madrigal, strongly supported Alunan's position and concluded its vehement editorial with the words, "By all means Davao should be a closed port. It should be put back where it always belonged."'39 The other two Manila English-language dailies, the Tribune and the Bulletin, both took vigorous issue with Secretary Alunan. The Tribune denounced him as having "naively pronounced" a "fallacious economic philosophy,"40 while the Bulletin editorialized that if Alunan's policies were followed the results would be "suicidal." 41 
Representative Isidro Vamenta of Misamis Province on Mindanao, who had recently visited Davao, declared his opposition to the closing of the port of Davao and said that Japanese landholdings were "apparently occupied in accordance with the law."42 Collector of Customs Vicente Aldanese also opposed Alunan's recommendations, ${ }^{43}$ as did Secretary of Finance Miguel Unson, who predicted that if Davao were closed as a port of entry, the accompanying rise in transportation costs would destroy Davao's trade. Samuel Gaches, prominent American businessman and community spokesman, who had also recently visited Davao, said that not only Japanese but Filipino and American businessmen as well would suffer from any closing of the port of Davao.

Leaders of the Davao Japanese community naturally voiced their opposition to the Alunan proposals. They did so by denials that the domestic or foreign trade of Davao was Japanese-dominated and by threats to move their hemp-growing operations to the Netherlands East Indies. ${ }^{44}$ Japanese Consul General Koshida Saichiro, summarizing the situation for the Foreign Ministry, wrote:

This problem deeply concerns the Japanese in Davao. Though from evaluating present opinion it seems that no change will take place, considering that the source of this problem is the person who occupies the key position of Secretary of Agriculture and Natural Resources it must be viewed rather gravely. ${ }^{45}$

While the controversy engendered by Secretary Alunan's report continued, one of the Secretary's principal deputies, Serafin Hilado, Chief of the Bureau of Lands of the Department of Agriculture and Natural Resources, sent word through Jose P. Laurel, Manila consulting attorney to the Ohta Development Company, that he would like to have a talk with Japanese Consul General Koshida. On July 17, 1930, the two men met. In what seemed to be a follow-up to the questions raised by Alunan, $\mathrm{Hi}$ lado evidenced his concern about Davao lands acquired in the past by the Japanese through marriage or common-law relations with local women, through pakiaw contracts, or through the extension of credit by Japanese companies to other companies 
which were in reality Japanese-controlled. ${ }^{46}$ Koshida replied that marriage was certainly not illegal and that the legality or illegality of the pakiaw system was still a moot question. However, his meeting with Hilado coming on the heels of the Alunan statement greatly troubled the Consul General, who called in Morokuma Yasaku, the head of the Ohta Development Company and President of the Japanese Association of Manila, to discuss the points raised by Hilado and to plan counter strategy. The two men decided that the best chance to gain an understanding of the Japanese side of the Davao problems raised by Alunan and Hilado lay with the "politically motivated" Philippine Legislature. ${ }^{47}$

On July 24, Watanabe Kaoru, Manila representative of the Ministry of Trade and Industry, invited Senator Benigno S. Aquino, Chairman of the Mindanao and Sulu Survey Committee, who had been described as a "person trusted by Senate President Pro Tem [Sergio] Osmena," to eat at the Fujikawa Hotel where Watanabe was living. During the meal Watanabe asked Aquino his views on the land contract situation at Davao, and Aquino answered that such contracts were not contrary to the land laws. Meanwhile, Morokuma met with his good friend Senate President Manuel L. Quezon, whose opinion was identical with that of Aquino, after which Morokuma asked one of his consulting attorneys, Pablo Lorenzo of Zamboanga, to sound out Osmena. Much to the consternation of the Japanese, Morokuma reported to Consul General Koshida that Osmena had told Lorenzo that the situation could not be left as it was because of all of the interest that had been aroused. Osmena further stated that since this was a question affecting foreign relations, its resolution depended on unreserved mutual understanding and that his hope was to limit the number of Japanese landing at Davao. ${ }^{48}$ Koshida told Morokuma that Japan could not agree to any such restrictions, for if Japan did agree, as China earlier had, this would undoubtedly be only a first step in an attempt to end all immigration of Japanese. Thus, both the Consul General and the President of the Japanese Association of Manila determined 
to avoid any such proposal and to strive to prevent the realization of Osmena's recommendation. ${ }^{49}$

The wisdom of Consul General Koshida's belief that Alunan and Hilado could best be countered through the Philippine Legislature was well supported by the contents of a letter which was addressed by Senate President Quezon to a leading Japanese businessman with interests in the Philippines:

Aboard S. S. Empress

At port in Yakohama,

of Japan

August 14, 1930

My dear Mr. Inouye:

Referring to the question which you asked me about the closing of the port of Davao, I wish to reiterate what I told you, namely: that the statements attributed to Secretary Alunan to that effect is [sic] not true. The Philippine Government, realizing the importance of Davao as a port of entry, has spent considerable money on wharves and other improvements to facilitate the unloading by ships of large tonnage, and it will be unthinkable, after so much work done, to close the port now to foreign entry.

I wish you would convey to your associates in your company the idea that the Philippine Government is not unsympathetic to Japanese capital, and that therefore they should not pay any attention to rumors and newspaper reports to the contrary. You may rest assured that legitimate Japanese investments in the Philippines which are made under our laws will be duly protected and will receive as much sympathetic consideration from our Government and people as if given to Filipino capital itself.

Thanking you for your courtesies, and hoping that the little souvenir I am sending you from the Philippines will be accepted as a token of my personal regard,

Very cordially yours,

(sgd) Manuel L. Quezon

Mr. N. Inouye,

No. 9, Nishitenjin,

Nishisuma,

Kobe, Japan ${ }^{50}$

Indeed, despite the opinion of Osmena earlier reported by Morokuma, meaningful support for the views of Secretary Alunan was noticeably lacking among the Filipino ruling elite. The sentiments of Quezon were those which prevailed, and the Alunan proposal died aborning. 
Also during the month of August, 1930, still another opportunity developed in which the Japanese Consulate General could make its influence felt among the Filipino legislators. This was a so-called unofficial visit to the Islands by a South Seas Inspection Party of the House of Representatives of the Japanese Diet. The seven-member party (four Minseito and three Seiyukai) arrived in Davao where they were met by Governor General Dwight F. Davis on August 12, and left the following day, arriving in Manila August 16, and staying until the 22nd. An especially warm welcome was extended to the Japanese group by the Philippine Legislature, including a luncheon on August 20, at the private home of Senate President Pro Tempore Osmena with fourteen leading members of both Houses as special guests and nine leaders of the local Japanese community as honor guests. The same afternoon at four o'clock House Speaker Pro Tempore Antonio de las Alas gave a formal reception and champagne party in his office, immediately followed by a joint legislative session at which a speech of welcome was delivered by Representative Arsenio Bonifacio and a brief statement of thanks was given in Japanese by the head of the Diet mission Okamoto Jitsutaro.

Representative Bonifacio's remarks were even more effusive than one familiar with the practices of Filipino oratory might have anticipated. He termed the visit of the Japanese delegation "one of the eventful episodes in the common history of the two neighboring nations" and "an added link to the chain of friendship that binds the two peoples in whose veins runs the adventurous Malay blood." ${ }^{51} \mathrm{He}$ enumerated and lavished praise on such Japanese characteristics as thrift, industriousness, chivalry, and appreciation of beauty, and he voiced the hope that an independent Philippines could in the future emulate Japan's remarkable advances in finance, business, and industry.52 Okamoto's reply was very brief, most humble, full of respect for the rapid progress of the Filipinos toward self-government and notably lacking in any political overtones.

After the Diet delegation had come and gone, Consul General Koshida reported to the Foreign Office that all members of the parliamentary delegation had, in accordance with Koshida's 
instructions, exercised great caution in both words and deeds. In fact, the Japanese Consul General judged the visit to have succeeded in carrying out a friendly exchange which had proved very favorable to Japan. He was particularly pleased with this result, since he noted that public opinion in the Philippines had been rather disturbed as a result of the recent publicity given to the situation in Davao by the Alunan Report and had mistakenly believed that the Diet party had come to the Islands principally to inspect conditions in Davao and to consider the problems of Japanese-Philippine relations. However, Koshida stated that because of the very brief period of time the mission spent in Davao such an erroneous conception of the purpose of their trip had been quickly dispelled. If, on the other hand, said Koshida, the Diet group had stayed in Davao a fairly long time, this would in the light of recent events in the Philippines have given rise to various speculations and opinions which could be of concern in the future. ${ }^{53}$

That there was still the possibility of stirring up controversy about Davao was, however, made very evident by a series of exposé-styled articles appearing during the fall of 1930, in the influential American-owned weekly magazine Philippines Free Press. The series was climaxed with the publication in the October 18 issue of the magazine of "an astonishing secret letter." The purported letter was supposed to have been written some fourteen years earlier in 1916, and to have come at that time into the hands of the Free Press, which claimed to have refrained from publishing it then in the interest of Japanese-American relations. The sensational document was said to have been composed by Japanese interests in the Philippines for delivery to the then Prime Minister of Japan Count Okuma Shigenobu by Okuma's close friend Dr. Nitobe Inazo, who had reached Manila on March 29, 1916, as a member of a Japanese South Seas Tour Party of some 61 persons. According to the Free Press, a loyal, patriotic Filipino who worked for the Japanese had secured a copy and delivered it to the Free Press.

The core of the letter, as published in English by the Free Press, was a proposal that Japan purchase the Philippines from 
the United States, and that in return for America's agreement to sell, Japan would pledge never again to permit Japanese laborers to immigrate to the United States. This recommendation was bolstered by such reasons in the alleged text of the letter as that the Philippines had been a bone of contention in the United States since their acquisition, that the annual population growth in Japan was 600,000 , necessitating some place to which the surplus population could migrate, and that while the United States needed Japanese labor, it was determined to exclude it. Therefore, the letter maintained, for a price in the neighborhood of P400,000,000 exclusive of railroads, the United States would be rid of the Islands, and Japan would be rid of its surplus population. And finally the Philippines would then form, together with the Kuriles and the Carolines, an island bulwark assuring Japan's security.

Having at last published what it termed "this audacious letter," in the same issue the Free Press proceeded to editorialize:

While American and Filipino officials drift along, allowing things to take their course and pursuing a general laissez-faire theory, the Japanese are planning definitely for the future. The series of articles on Davao published in the Free Press climaxed this week with the startling revelations on page two, definitely prove that fact.

No nation in the world has progressed with the leaps and bounds that Japan has in the past two or three decades. From comparative obscurity, Japan has risen to a world power, which must be considered in every meeting of the great nations. And Japan's designs on the Philippines are far from a myth.

Compare the systematic and organized Japanese methods with the wavering and vacillating attitude of the United States-which seems to include a change in insular administrations every couple of years-and the helter-skelter policy of local politicians-interested only in self-aggrandizement-and you will realize what the future must inevitably hold for the Philippines. ${ }^{54}$

Consul General Koshida, in reporting and analyzing for the Foreign Office this latest outburst of what he termed anti-Japanese propaganda, attributed the attitude of the Free Press in part to riding the crest of the wave of criticism directed at the Japanese in Davao since the publication of Secretary Alunan's report and in part to the presence on the Free Press staff of an American editor and three other Americans, one of whom was 
reported to have a connection with the traditionally anti-Japanese Hearst press. The latter individual, according to Koshida, wanted, in line with the local American Chamber of Commerce, to prevent American withdrawal from the Philippines. ${ }^{55}$

As far as the letter itself was concerned, the Consul General reported that a search of the consulate's files showed that a South Seas Observation Party organized during 1916 by the O.S.K. steamship company with the assistance of the Taiwan Government General had reached Manila on March 29, and had remained 31 hours. The group then sailed on the 20th for Zamboanga, where it stayed 11 hours en route to Sandakan, North Borneo. According to the records, while in Manila the party had been given a reception at the consulate, where the head of the local Mitsui branch talked on the development of Philippine industry and Dr. Nitobe spoke on South Seas economic development. However, there was no trace whatever of any such letter as the one reported by the Free Press. ${ }^{56}$

Although Consul General Koshida concluded that the letter must be a forgery, he said that since there was always a remote possibility that the letter might have emanated from some source unknown to him, the consulate could not afford to dismiss it out of hand if questions were raised about it. Rather, he proposed that if there should be any queries about the letter, the consulate should reply truthfully that it had absolutely no knowledge of such a document and should comment on it in terms of its date, its unofficial character and the preposterousness of its contents. But, Koshida concluded, he doubted that any of this would be necessary since, despite what he believed to have been the obvious intent of the Free Press to stimulate anti-Japanese feelings, there had neither been any apparent Filipino reactions to the letter nor had any other organs of the Philippine press published any opinions in regard to it. ${ }^{57}$

Nevertheless, American concern over the developing Japanese enclave at Davao continued to be evident. Worrisome reactions in the United States were undoubtedly stimulated by both the "statesmanship" of the Alunan Report and the sensationalism of the Free Press articles. For example, when on 
February 10, 1931, former Philippines Governor General W. Cameron Forbes, then United States Ambassador to Japan, arrived in Manila to pay a visit to Governor General Dwight Davis, the New York Times chose the occasion to review what was called the "peaceful economic invasion" of Davao. ${ }^{58}$ The Times estimated that the Japanese population of Davao Province was then 10,000 and that $85 \%$ of hemp production in the Philippines was "handled by Japanese." This included both the shipping of hemp on Japanese vessels and the utilization of Japanese laborers on American or Filipino plantations as well as on Japaneseowned plantations.

The Times also noted that Japanese labor was not only more efficient but more economical than Filipino labor since the Japanese were willing to work under a crop-share plan, whereby the plantation owner held a crop auction in the presence of his laborers, and they in turn were paid a specified share of the amount for which the abaca crop was sold. Moreover, according to the same report, the Japanese had introduced machine stripping, which meant both increased and cheaper production of hemp with less labor. Further, the Times stated, it was the Japanese who had increased the profit margin still more by the utilization of hemp waste, especially by establishing an experimental paper mill. Since the normal profit margin in hemp was rarely over $15 \%$, that margin was most often determined by the economies of production and by the utilization of byproducts. In conclusion the Times noted that the latest suggestion for dealing with the Japanese influx was the Alunan-instigated proposal for closing the port of Davao, a proposal which, as the Times viewed it, had been foredoomed by virtue of the fact that the transport of hemp to Zamboanga would so add to the cost of the hemp that the profit would be eliminated and the abaca industry with it. $^{59}$

\section{Investigations of Davao: American and Philippine}

Within the year that followed, Japanese aggression in Manchuria and the Japanese attack on Shanghai, both in seeming disregard of accepted international practices, profoundly affected 
American public opinion. In the United States increased attention was focused on the security of the Philippines, and once more the Japanese settlement in Davao was in the limelight. In line with this concern, on February 11, 1932, Acting Governor General George Butte made an official inspection of the Davao region. After holding a public hearing at which he heard some testimony very critical of the Japanese and after a brief tour of the area, he returned to Manila and had the Bureau of Customs promulgate over his signature Customs Administrative Order No. 284, which designated Manila as "the only port where alien immigrants or returning residents may enter from abroad."60 Prior to the issuance of this order immigrants had been permitted to enter the Philippines through the subports of Iloilo, Cebu, Zamboanga, Jolo, and Davao, as well as through Manila, but ostensibly Chinese immigration required closer supervision and control, and therefore subports were to be eliminated. ${ }^{61}$

However, Dr. Butte on his return from Davao was quoted as having said that the district was "entirely in the hands of the Japanese" and that, while they had done "wonderful work in commercial expansion," they presented a "natural strategic problem, since 12,000 are concentrated in a small area and control the political and economic life of the entire province." ${ }^{2}$ When it was also made known that the Acting Governor General had, at the same time the new order on immigration was made public, reserved by executive order vast tracts of land in Davao for homesteads and had canceled some one hundred applications of Filipinos seeking shore leases on the Gulf of Davao because the applicants were "acting for Japanese third parties," 63 there was no doubt at all that his actions were directed at the Japanese. The Davao question was once more in the forefront of Philippine politics and of Japanese-American relations.

In a memorandum to the Secretary of War with reference to the above press reports, General F. Le J. Parker, Chief of the Bureau of Insular Affairs, defended Dr. Butte by saying that "action and comment of the type alleged are matters of discretional judgment on the part of the Philippine Chief Executive." 64 Parker also stated that based on his personal observations in the 
summer of 1931 there was an "undesirable concentration of Japanese immigration and influence in Davao Province and that ... further extension of that influence is not improbable and not in the best interests of the Filipino people." ${ }^{\prime 65}$ There is a strong indication in the same memorandum that Gen. Parker was in fact pleased with the possible effect in the Islands of the remarks of the Acting Governor General since "until quite recently, the general public attitude of the Filipino leaders has been that the Philippine Islands had nothing to fear from Japanese immigration or penetration."

Subsequently on March 5, 1932, a cablegram was received in Washington from Governor Butte, replying to an earlier message from General Parker asking about the accuracy of the press reports of Butte's statements. ${ }^{67}$ Butte reported that he had only inspected the municipality of Davao and that the "generalizations" contained in the press were therefore inaccurate for the province though accurate for the municipality. There were, he said, 12,507 Japanese in Davao Province (total population 139,000 ), the majority of whom lived in Davao City (population 21,500). It was estimated, he reported, that Japanese interests controlled all of Davao's timber production, $80 \%$ of its hemp production and $50 \%$ of its copra production. During 1931, of the ships entering the port at Davao, twelve were American, sixteen were British, one was Dutch, one was Norwegian, and 65 were Japanese. ${ }^{68}$

Dr. Butte attributed his statement on the extent of Japanese political influence among the elected officials of Davao, all of whom were Filipinos, to reports received from the Director of the Bureau of Non-Christian Tribes and from the Deputy Governor of Davao and to his own observations. Therefore, contended Butte, Davao with its large Japanese population, its Japanese-controlled harbor and Japanese-owned docks, and some 325 kilometers of Japanese-built private roads is a "potential military base," and any measures taken to impede its rapid development were warranted. As far as the executive order closing subports as ports of entry for aliens was concerned, he said that it was issued on unanimous recommendation of the cabinet and 
was directed principally at the Chinese but gave discretionary authority to local Collectors of Customs to make exceptions. As far as the lease cancellations were concerned, Butte concluded, an executive order in 1921 had set aside the Davao waterfront as a provincial reservation, and thus the Provincial Board was forbidden to alienate those lands, so that the specific permits now withdrawn had never been valid anyway. ${ }^{69}$

Although subsequent mollifying statements by Consul General Kimura Atsushi, ${ }^{70}$ plus the revocation of Customs Administrative Order No. 284 on June 23, 1932,, ${ }^{71}$ and a consequent resumption of the former system of subports of entry for immigrants, eased the somewhat tense atmosphere created by Butte's actions, it was clear that two new factors had entered the picture of the situation of the Japanese settlement in Davao. One was, as noted earlier, Japan's aggression in and conquest of Manchuria, and the other was the increasing possibility that the American Congress would grant independence to the Philippines. Moreover, these two developments were very much related to each other. For the Japanese action in Manchuria had turned the spotlight on the whole question of Philippine security and placed in rather dramatic highlight the problem of the ability of an independent Philippines to defend itself. Thus, the concentration of Japanese in Davao quite suddenly assumed entirely new and seemingly much more menacing overtones as it affected both Philippine-American and Japanese-American relations.

As far as action by the Filipinos themselves in regard to the Japanese in Davao was concerned, in late 1931, the House of Representatives of the Philippine Legislature passed a resolution setting up a special Committee to Investigate Mindanao Lands in order to examine thoroughly the problem of illegal acquisition of land. The Committee was to carry out its investigation and report its findings and recommendations to the next session of the Legislature. Though the Committee was charged generally to study the land situation in Mindanao, it was obvious that its principal objective was to try to clarify the current status of landholding by the Japanese. The committee's own inspection team 
was made up of nine of the twelve House members appointed to the Committee plus two secretaries. They left Manila on April 25, 1932, following the close of the legislative session and returned on May 17.

The Committee was actually in Davao from April 30, to May 8, when they left to return to Manila via Cotabato, Lanao, and Zamboanga. Their method of operation at Davao was to spend several hours each day receiving visitors, hearing appeals of various sorts, and holding public hearings. In addition, subcommittees made up of two or three Representatives made field inspection side trips to various key hemp growing areas. The Committee's visit created a few peculiar problems of its own and aroused an interesting variety of reactions.

From the time the inspection mission was publicly announced, the various Japanese firms in Davao-Ohta, Furukawa, etc.-planned welcoming celebrations and receptions of their own for the group. However, subsequent consideration of the idea and consultation with the Acting Consul of Japan in Davao, Vice Consul Kaneko Toyoji (on Feb. 6, 1932, the Davao Consular Annex had been raised to a Consulate), led to the cancellation of these affairs in order that they not become targets of criticism. But Consul Kaneko decided that he himself, as a representative of a neighboring and friendly country, might well give a tea party for the group in order to exchange courtesies. Nevertheless, after the Committee arrived in Davao and the invitation was extended, Kaneko was informed that the visiting legislators were much too busy to accept any social obligations. When word filtered back to certain of the Representatives that the Consul was somewhat offended at the summary brushoff his proffered hospitality had been given, the Committeemen were highly incensed since the negative response had been arbitrarily made by the Chairman, Representative Fabian de la Paz, acting entirely on his own. Finally, pressure from his colleagues forced Representative de la Paz to extend apologies to Consul Kaneko. ${ }^{72}$

At a public hearing of the Committee on May 6, the same witnesses who had evidenced their hostility in testimony before Acting Governor General Butte in February appeared to com- 
plain of illegal acquisition of land by the Japanese and of corrupt practices on the part of Filipino officials. However, Consul Kaneko noted that the complainants were known locally as "notorious characters" and that their testimony was considered to be little more than a way of attracting attention to themselves. Thus it seemed to create almost no impact. ${ }^{73}$ Nevertheless, Kaneko did remark that while many of the local Filipino officials and influential individuals who in the past had themselves leased to the Japanese farm land sold by the government or had arranged such leases outwardly showed indifference toward the investigation or advocated a boycott of the inspection party, their seeming unconcern was only a facade for what was in reality a profound sense of uneasiness. ${ }^{74}$ As specific examples, the Japanese Consul General mentioned then Davao Governor Juan Sarenas and Chief of the Davao office of the Bureau of Lands Reyes. Sarenas who had long been an attorney for several Japanese firms said he regarded the investigating committee as meaningless since, if there were anomalies, it would have been proper for his office and for the local branch of the Bureau of Lands to investigate at the local level rather than to send a high-powered group from Manila. Reyes stated that although the Committee was supposed to investigate whether there had been any violations of the land laws by either Filipino or Japanese, coming to Davao like ordinary tourists and spending only a week there could hardly accomplish anything. ${ }^{75}$

After the Committee's return to Manila, the press was full of rumors of their supposed findings and of possible proposed solutions. Most of these reports emphasized the theme of presumed illegal acquisition of land by the Japanese in Davao and of possible connivance of Filipino officials in this process. The principal rumored solutions proposed to these problems were either the cancellation of illegally acquired land ownership by legislative action or the outright purchase of Japanese-held lands by Filipino or American capital or by the issuance of bonds by the Philippine government.

Since, however, it was in fact extremely difficult to prove or disprove most of the charges against the Japanese of illegally ac- 
quiring land, ${ }^{76}$ and since the tireless lobbying of the consulate and of representatives of the Japanese community made remedial legislative action almost impossible, the net result of the investigation of the special committee of the Philippine House of Representatives was the passage on September 12, 1932, by the Legislature of a Joint Resolution accompanied by an explanatory statement. The statement noted four significant facts about the Japanese in Davao: the lack of any restriction on Japanese immigration to the Philippines and the opening of a direct steamship route from Japan to Davao had both contributed to a rising trend in the number of Japanese arrivals there; the concentration of Japanese population in Davao had now reached 15,000; many Filipinos in Davao had leased the maximum 1,024 hectares of public land from the government only in order to sublease the same land in turn to the Japanese; and since the Chinese began boycotting Japanese goods in reaction to Japanese aggression in Manchuria, the number of Japanese retail stores had increased greatly. The Joint Resolution, therefore, simply called on the executive branch to enforce the land laws as strictly as possible. ${ }^{77}$

\section{Davao: A Continuing Japanese Success Story}

Implicit, of course, in the outcome of the Philippine legislative investigation of Davao was the recognition of the fact that the Japanese had indeed made a success of the Davao settlement. Statistics, including those supplied by the Japanese, as well as overt evidence made it very clear that restrictive legislation, for example the Land Law of 1919 (Act No. 2874), had failed to impede the growth of the Japanese stake in Davao. Figures of the provincial assessor of Davao Province for 1932 showed that as of that year there were 25 Japanese controlled firms with holdings in excess of 1,000 acres and that total Japanese landholdings included: ${ }^{78}$

Purchased from the government with titles 2,986 acres Purchased from individuals 10,516 acres Leased from the government 53,401 acres Leased from individuals 13,259 acres

Total 80,162 acres 
The assessed value for 1932 of taxable property (land value only since improvements were not assessed in the provinces) owned by the Japanese was said to be $\mathrm{P} 7,317,090 .^{79}$

In a secret report to the Foreign Office in June of 1932, Acting Consul at Davao Vice Consul Kaneko Toyoji listed Japanese investments in the province of Davao as follows: ${ }^{80}$

Agricultural Companies P20,000,000

(43 companies and one individual)

Self-sustaining Persons $\mathrm{P} 10,000,000$

(About 2,000 tenants)

Self-sustaining persons on foreigners' cultivated land P 5,000,000 (About 500 persons)

Commercial and industrial enterprises P 5,000,000 (About 200)

Lumbering and sawmill enterprises P $1,600,000$ (7)

Fishing enterprises P 200,000 (15)

Total $\mathbf{P} 41,800,000$

As far as population was concerned, Acting Consul Kaneko stated that as of 1932 there were 12,992 Japanese in Davao, of whom 7,327 were farm laborers and their families. ${ }^{81}$

Generally speaking, however, Filipinos did not at this juncture evidence any great concern about the Japanese in Davao. Nevertheless, the American authorities, and in particular Governor General Theodore Roosevelt, Jr., who had been appointed to his post in February, 1932, increasingly interested themselves in the Davao situation. In June, 1932, Roosevelt himself made a personal visit to the region, where he heard repeated every charge that had been made to former Acting Governor General Butte, as well as to the Philippine legislative investigating committee. Roosevelt recorded his findings and opinions in a lengthy confidential letter to General Parker.

Roosevelt wrote that he saw the Japanese making marked advances in every aspect of their endeavors because "their organization is compact and sound at every stage, their leadership able, their technical advisory aid the best obtainable, and, if they dominate the commerce and agriculture of the Davao area, as assuredly they do, it is not because of numbers, for they are 
outnumbered twelve to one, but because of sheer demonstrated efficiency." 82 The Governor General, however, saw a number of disadvantages accruing from the dominant position of the Japanese in Davao: they had secured veritable control of the richest agricultural and timber lands in the area; they had greatly reduced the commercial importance of Zamboanga and Cebu; they had spent in Japan much of their earnings which would have been spent in the Philippines or the United States by Filipinos or Americans; they had alienated lands belonging to non-Christian tribes; and through their economic power they had brought local officials under their influence.

But as agitation for Philippine independence increased both in the Islands and in Washington, Governor General Roosevelt, as the highest American official in the Philippines and as a representative of the President of the United States, saw one disadvantage stand out more vividly than all others. In his belief:

.. . the situation in Davao presents a potential menace to the security of the Islands. That the Japanese are firmly entrenched there, that they are extending their influence, that they dominate the hemp and lumber business in that region, there is no shadow of doubt. That they are planning future expansion with further extension of their control over hemp, coconut, timber and cattle land is probable. And finally, that in the event of the withdrawal of American sovereignty there will be an immediate and positive advance along all lines there is likewise little doubt. The weakness, richness, and proximity of the Islands present altogether too lucrative a stake for Japan to ignore, and should American protection be withdrawn, then Japanese economic exploitation and political penetration will at once become a very real threat. ${ }^{83}$

What Roosevelt failed to state, however, was that, even if everything he had said of the position of the Japanese were true, the progress of the Japanese settlement there had occurred in the beginning with the encouragement of the Americans and subsequently by virtue of their tolerance. Moreover, Roosevelt himself was not only personally strongly opposed to Philippine independence and therefore looking for every possible reason to bolster a conclusion he had long since reached, but he was also the representative in the Islands of an administration in Washington that was equally opposed to independence and therefore perhaps equally eager to magnify the situation in Davao. 
Despite the somewhat alarmist views of a Theodore Roosevelt, Jr., however, the great potential of Davao was still practically unexploited. Moreover, since the total acreage of the province was over 3,250,000 acres of which nearly $70 \%$ was estimated to be arable and since the total population of the province was in the neighborhood of 170,000 , in realistic numerical terms Japanese "penetration" was infinitesimal. Japanese capital, organization, direction, efficiency, and, above all, hard work had certainly begun to scratch the profitable surface of Davao's untapped wealth. Yet there was no apparent reason why Filipinos themselves should not do as well or in fact outstrip the aliens in their midst. Describing the development of Davao by the Japanese the Herald could justifiably editorialize:

The story of Japanese prosperity in Davao is the story of the surrender of a national heritage, of unpardonable indifference, of shameful neglect. In it are reflected the procrastination of our government and the apathy of our people. Our generation to come will read in that story the dismemberment of their national domain and the barter of their rights. ${ }^{84}$

For all the investigations of supposed Japanese chicanery at Davao were often little more than smokescreens for the failure of the Philippine government and the Filipino people to address themselves with energy and purpose to the exploitation of their own land. No matter how illegally the Japanese had obtained land, and indeed in many cases their methods seemed outrageously unethical, in the end the clearing of that land and its subsequent productivity were the real measures of its value. To achieve these results required plenty of capital and unstinting labor. The former was copiously supplied by Japanese corporations and banks with the support and sympathetic cooperation of the Japanese government while the latter was provided by frugal, disciplined immigrant workers from Japan, men whose work habits were exemplary, whose labors were marked by a high degree of cooperative effort, whose women shared their husbands' hardships, who kept themselves clean, who ate simple but nutritious food and were careful of their drinking water, and who slept only from 8 or 9 p.m. to 3 or 4 a.m. Thus it 
was that without sufficient or coordinated government financial support or technical assistance and lacking the same psychological drive which motivated the Japanese laborer even the Filipino homesteader in Davao very quickly left his land and became a cargador at the bidding of a Japanese overseer. As one writer so aptly stated, "Facing the stiff competition given him by the Japanese who are furnished capital and who are by nature better farmers and trained in the art of coaxing plants to give greater returns, the Filipino homeseeker prefers to sell his interest on the land to the Japanese and work for him." 85

Moreover, since the direct acquisition of land by the Japanese was the principal obstacle to the development of the Japanese agricultural stake at Davao, the Japanese became almost totally dependent on indirect acquisition by means of the several techniques described earlier. And because at almost every turn the success of these techniques depended on the goodwill of Filipino government officials at the provincial or national level, the Japanese perforce evolved a modus operandi with Filipino officialdom which, while admittedly never entirely secure and often somewhat costly, nevertheless permitted a continuous and substantial expansion in Japanese investments in the Davao area. Much of the time of the Japanese consular staff in both Manila and Davao seemed to be taken up by both public and private arguments with Filipino officials over the legality or illegality of this or that specific arrangement for Japanese cultivation of a given tract of land. In reality, however, of far greater significance to the security of Japanese interests was the extent to which influence could be brought to bear on individual officials, on the basis of interpersonal relationships either between Japanese and Filipinos or between Japanese-employed Filipinos and other Filipinos.

For example, during 1933, reports from the Japanese consulate at Davao indicated that pressures which during the preceding year had been directed at subleases to the Japanese under the pakiaw system had been markedly relaxed. Davao Acting Consul Kaneko attributed this development to the friendly relations which had been maintained between the Davao consulate 
and local officials of the Bureau of Lands as well as to the similar contacts secretly existing between the consulate and provincial officials, several of whom were themselves lessors of land to the Japanese. ${ }^{86}$ It was also noted that there had been an apparent relaxation in the attitude toward enforcement of land laws on the part of the Chief of the Bureau of Lands Serafin Hilado, who in the past had been particularly strict in regard to the Japanese cultivators at Davao; and in October, 1933, the new Chief of the Bureau of Lands, Simeon Ramos, upheld the legality of the pakiaw system. ${ }^{87}$ In some measure this was believed to have come about because of the intervention of former Senator Jose P. Laurel, principal legal adviser to the Japanese Consulate General in Manila, who had told a member of the Davao consular staff that he himself was strongly opposed to any interference with the rights of the Japanese to pursue their business activities peacefully and that he would do his utmost to protect those rights. ${ }^{88}$

Typical of the improved situation at Davao, according to Consul Kaneko, was the atmosphere at a dinner party tendered by local officials to the visiting House of Peers South Seas Inspection Party from Japan on June 25, 1933. Kaneko reported that in attendance at the affair were about one hundred leaders of the Davao community-businessmen, lawyers, journalists, plus ten or so Americans, and a few Chinese. Besides the Governor and several local officials, seven or eight other persons gave welcoming speeches, and all commented on the remarkable efforts and successes achieved by the Japanese in developing Davao. There were even some who said that after independence the Philippines must depend on Japan for leadership and protection. Observed Kaneko happily, "In the last ten years there has rarely been such a successful party." 89

Thus, generally speaking, despite certain momentary disruptions, the path of the Japanese to continued economic advance in Davao was actually relatively smooth, and the scope of that advance was well reflected in statistical data. A report of the Bureau of Insular Affairs for the province of Davao for fiscal 1934 showed the following: ${ }^{90}$ 
Total population:

Christian Filipinos ................................................... 105,071

Non-Christian Filipinos …................................... 80,125

Americans …........................................................ 150

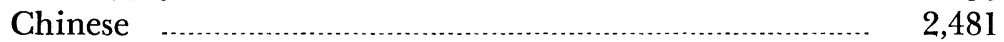

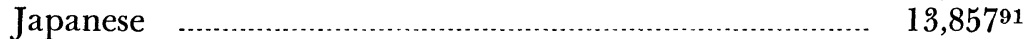

Other Foreigners …................................................... 342

Total ................................................................. $\overline{202,026}$

Realty Holdings of Foreigners:

\begin{tabular}{|c|c|c|}
\hline & Area in Hectares & Assessed Value \\
\hline Japanese & $\ldots .38,774.0366$ & P9,569,930.00 \\
\hline Chir & $6,846.0905$ & $2,096,910.00$ \\
\hline Spaniards & $6,558.8840$ & $815,400.00$ \\
\hline
\end{tabular}

Detail of Realty Holdings of Japanese:

(a) Purchases from Government or from Individuals, Land Area6,161.8884 Ha.; Value-P890,690.00. (b) Leases from Government or from Individuals, Land Area-32,613.0482 Ha.; Value-P588,290.00. [Improvements in abaca, coconut, and fruit tree cultivation, and in plants, machinery, and buildings substantially increased these values.]

Japanese Percentage of Participation in Davao Province Industries:

\begin{tabular}{lr}
$25 \%$ of Farming & $75 \%$ of Carpentry \\
$5 \%$ of Copra Drying & $70 \%$ of Furniture and \\
$60 \%$ of Fishing & \multicolumn{2}{c}{ Cabinet Making } \\
$5 \%$ of Cattle Raising & $60 \%$ of Tinsmithing \\
$40 \%$ of Hemp Stripping & $50 \%$ of Photographic Studios \\
$60 \%$ of Tajore Making & $80 \%$ of Refreshment Parlors \\
$100 \%$ of Soft Drinks & $50 \%$ of Ice Plants \\
$60 \%$ of Odong Manufacturing & $100 \%$ of Sawmills \\
$60 \%$ of Taoyee & $50 \%$ of Firewood Industry \\
$60 \%$ of Lumbering & $5 \%$ of Trucking \\
$67 \%$ of Blacksmithing & $23 \%$ of Merchants \\
$50 \%$ of Gold and Silver Works & $25 \%$ of Retail Tobacco Dealers \\
$15 \%$ of Tailoring & $32 \%$ of Retail Liquor Dealers \\
& $74 \%$ of Bicycle Repair Shops
\end{tabular}

Total Volume of Business Transacted in Davao Province, 1930-34:

P59,179,321.97

Total Volume of Business Transacted by

Japanese Individuals, 1930-34:

P12,793,966.38

Total Volume of Business Transacted by

Japanese Corporations, 1930-34:

P10,162,916.93

Clearly the major enterprise of the Japanese settlement in Davao was the raising of abaca for the making of hemp. By 1934, $80 \%$ of the abaca grown in Davao was being produced by the Japanese for a total annual production of 500,000 bales of hemp. ${ }^{92}$ So efficient were the methods of cultivation employed by the Japanese that an amount of land equivalent to that util- 
ized for the Japanese $80 \%$ was required to grow the remaining $20 \%$ of the provincial abaca production. In addition to exporting to Japan better than $95 \%$ of the total hemp produced at Davao, the Japanese also sent to Japan for industrial use (paper pulp, coarse rope, etc.) practically all of the "Grade W" (meaning waste) or abaca scrap which ordinarily was either discarded or used in the making of door mats. One further significance of Japan's control of the Philippine hemp industry was that the hemp trade did not depend on a protected market as did sugar or coconut oil. Thus, the impending termination of free trade with the United States with the coming of independence would not affect hemp, which had no need of any artificial protection. It was, therefore, probably as much alien control of a key sector of the Philippine economy as it was suspected illegal acquisition of land that caused a series of charges against the Japanese in Davao to be aired and publicly debated beginning with the Constitutional Convention in 1934.

\section{The Philippine Constitutional Convention and Davao}

In a message dispatched to Foreign Minister Hirota Koki on July 26, 1934, Acting Davao Consul Kaneko had warned his superiors in Tokyo that there was a possibility that the Convention might make decisions unfavorable to the Japanese in such vital areas as naturalization, immigration, and landholding. Under the provisions for Philippine independence in the Tydings-McDuffie Act, the President of the United States had to approve the Philippine Constitution before the ten-year transition period to independence could be inaugurated. Therefore, the Japanese were particularly fearful lest the Filipinos, in order to further the likelihood of swift American approval of their Constitution, include in it articles designed to pander to American apprehensions about the Japanese interests in the Islands.

Kaneko reported that he had already had a conversation about these matters with Davao Delegate Rafael A. Castillo who, according to Kaneko, was a friend of the Japanese and who had agreed to work against any anti-Japanese proposals. Kaneko 
urged Castillo to get in touch with former Senator Laurel and former Representative Lorenzo, attorneys in the employ of the Japanese, who were friends of Japan and who would assist Castillo. The Davao Acting Consul also warned the Foreign Office that the Convention delegates most likely to cause trouble were Vicente Singson Encarnacion, Miguel Cuaderno, and Salvador Araneta. ${ }^{93}$

However, the principal speech at the Convention on the subject of Japanese interests was not made by any of these men but by another delegate from Davao, Pantaleon Pelayo, who asserted that members of the legislature, constabulary officers and various government officials were involved in a profitable system of leasing public lands which in return for a share of the profits they would then sublease to the Japanese. Pelayo claimed that with the aid of such Filipino dummies, Japanese controlled $90 \%$ of the land in Davao Province, which he said was the richest province in the Islands. According to Pelayo:

Japanese interests in Mindanao have great influence upon the people there, especially those in the Government, especially the higher-ups in Mindanao, especially in Davao. To the lawyers, the Japanese are the best clients; to the doctors, they are the best patients; to the public officials, they are the best friends, especially when Christmas time comes. ${ }^{94}$

Pelayo also claimed that the Japanese were smuggling arms and ammunition into Davao, that they were fostering the illegal entry of immigrants into the region, and that, as a solution to both of these problems, the port of Davao should be closed.

Although ultimately the issue of alien landholding was dealt with in the Constitution only through the inclusion of Article XII, ${ }^{95}$ the charges leveled by Pelayo caused repercussions throughout the Islands; and the press, in particular, took up the issues that had been raised by Pelayo's speech. Once more public attention was focused on Davao, and the Japanese found themselves again on the defensive and seeking appropriate countermeasures. However, previous investigations of the Japanese in Davao by both the executive and legislative branches of the Philippine government; an increasing tendency toward an anti-alien Philippine nationalism, which had accompanied 
the growth of independence fervor; and an increase among both politicians and journalists of anti-Japanese propaganda since the Manchurian Incident certainly had kept both the local Japanese consular staff and the leaders of the local Japanese community on the qui vive. What seemed to have surprised the Japanese was that Pelayo should be the source of this renewed assault on their settlement at Davao, and what particularly concerned them was the response which his accusations seemed to arouse.

Nevertheless, with impressive speed Acting Consul Kaneko provided the Foreign Office with a candid and revealing analysis of Delegate Pelayo, and of the apparent motivations for his outburst. ${ }^{96}$ Pelayo, born in 1901 and graduated from law school in 1925, after passing the bar examination moved from Manila to Davao in 1926. Several years later he purchased sixty hectares of land in the Guianga region of Davao Province and hired seven or eight Japanese to cultivate hemp on his property. He also became, in his wife's name, the local agent of Heacock Company and of the Free Press. Although Pelayo had begun to participate in local politics almost from the time of his arrival in Davao, he had been largely overlooked by the Davao political elite because of his relative youth. However, in the summer of 1933, in the fight over the Hare-Hawes-Cutting Act, ${ }^{97}$ he gained a certain notoriety by teaming up with veteran Davao politicians Celestiano Chavez and Rafael Castillo in support of Quezon and the Antis and in the general election of that year by backing the former Governor S. T. Generoso, who was victorious over the incumbent Governor Juan Sarenas. It was in that same election that Pelayo himself was elected to be one of Davao's two delegates to the Constitutional Convention. Consul Kaneko noted that throughout his prior political career Pelayo had evidenced "arrogant and eccentric" conduct and wrote that some of Pelayo's own supporters were concerned about his "irrational behavior."

Because of the broad character of Japanese interests in Davao, it was of course necessary for the Japanese to have the best possible local legal representation, and not unexpectedly the leading Davao attorneys whom the Japanese hired were also 
prominent in local politics. For example, among the aforementioned politicos, Castillo, who was Pelayo's political ally and fellow delegate to the Constitutional Convention, had for years been an invaluable legal adviser to the Ohta Development Company as well as to other Japanese firms in Davao, and Sarenas had had a similar association with the Furukawa Plantation Company and two or three more Japanese enterprises. But, since Castillo and Sarenas were themselves bitter personal rivals, their opposition to one another, as in the recent gubernatorial campaign, inevitably involved the Japanese in controversies which were hardly of their own making. For it was widely rumored during the 1933 election that both the Generoso and the Sarenas groups were being assisted by the Japanese; and the Generoso supporters, in particular, joined of course by Pelayo, attacked Sarenas as being an appointed official of several Japanese companies in order to enhance his personal fortune. However, in reporting this information, Consul Kaneko who was extremely sensitive to the ways of Philippine politics, commented that these accusations were only campaign propaganda and had no malicious intent against the Japanese since Castillo, for example, bore the same kind of relationship as Sarenas to a number of Japanese firms, and Pelayo himself used Japanese to farm his land.

In examining Pelayo's reasoning in making his inflammatory speech, Consul Kaneko first pointed out to the Foreign Office the fact that the whole atmosphere which surrounded the Constitutional Convention unfortunately had a pronounced anti-Japanese cast. According to Kaneko, this atmosphere was the result of increasing concern on the part of many Filipinos about the whole range of relations with an apparently aggressive, expanding Japan at a time when Philippine independence was impending. Kaneko also placed some of the blame for the advocating of measures to curb Japanese economic activities and Japanese colonization on Filipino sugar and coconut growers. These latter groups, he said, in cooperation with certain government officials and American businessmen in the Islands, were attempting to stir up anti-Japanese sentiment in order to protect their 
own interests by supporting the continuation of free trade with the United States. As far as Pelayo himself was concerned, Kaneko opined that ever since his arrival in Manila, Pelayo had been questioned by his fellow delegates to the Convention about the Davao problem; and being placed in the anti-Japanese atmosphere of the Convention and desiring to be in the limelight, Pelayo had attempted to distinguish himself as a "patriot" by making his much discussed speech. Kaneko also thought that it was worthy of note that Pelayo had made his remarks at a time when his colleague Castillo had gone home on business.

For, in brief, Kaneko believed, and Castillo in a subsequent chat agreed with him, that Pelayo had hoped to use the Convention floor to direct the same kind of attack against his provincial political rivals led by Sarenas as had been made during the previous year's campaign and, in so doing, to focus attention on himself as the probable future political kingpin of Davao Province. However, given the prevailing climate of opinion at the Constitutional Convention, Pelayo's accusations against the Japanese (read Sarenas et al.), which in this instance went beyond the bounds that usually surrounded the political charges and countercharges at the provincial level, produced nationwide repercussions. And, while Manila opinion as reflected, for example, in the press and in the magazines seemed to take up Pelayo's statements with enthusiasm and gave them wide circulation, in Davao, according to Consul Kaneko, those who knew Pelayo tended to laugh at him for repeating such an "old story" as though it were his own discovery. The opposing Sarenas faction called Pelayo a "hypocrite" and derided Generoso and Castillo for having suported such a character for national office. Moreover, Kaneko reported that Castillo, who himself had many associations with the Japanese, was greatly angered by Pelayo's "grandstand play" and tried very had to make amends to the Japanese Consul.

As far as the charges made in Pelayo's speech were concerned, Consul Kaneko assured the Foreign Office that they were "false," "groundless," and in fact "childish." Of the 44 Japanese firms operating in Davao all but three had legally bought or leased 
public land under land laws enacted prior to 1919, or had acquired privately owned land. The remaining three companies, Kaneko continued, were organized under the land law then in force, and $61 \%$ of the stock in those firms was held by either Americans or Filipinos (including Sarenas) as the law required. The only problem then was the method by which the Japanese farmed leased land, the crop or labor contract-work principle of "obtaining a set percentage of the crop in recompense for the labor offered for a set period of time" (pakiaw system). However, since the Bureau of Lands had decided the preceding October that that system was in no way an infraction of the law, unless some as yet unforeseen new regulations were imposed, any interference with the pakiaw system seemed quite unlikely to Kaneko.

Consul Kaneko also dismissed the additional allegations of Pelayo that the Japanese were smuggling arms and ammunition into Davao as another "old story," which had been fostered ir the past by reckless and ambitious politicians or by certain unscrupulous local officials who used such charges to obtain funds from the national government in Manila for supposed "on-thespot investigations." Moreover, Kaneko related that, when on the 10th of October he had discussed Pelayo's speech with a group of Filipino dinner guests including one Major Ramos of the Mindanao district headquarters of the Philippine Constabulary, the Consul had asked, "Major Ramos, because of your duty and responsibility you must certainly know whether or not this talk [of the Japanese being involved in the smuggling of arms and ammunition] has any basis in fact. What is the real situation?" To this question, according to Kaneko, Major Ramos had replied, "There is no evidence at all of such smuggling."

Finally, in response to the accusation of Pelayo that the Japanese were entering Davao illegally, Kaneko commented that indeed during the earlier hemp boom some seamen had deserted their ships and a few crewmen from fishing boats had entered Davao without proper authorization. However, he estimated that no more than two hundred such persons remained. Otherwise there was no reason for any Japanese to attempt illegal entry 
since there was no legal restriction against their coming to the Philippines. Therefore, reported Kaneko, since Japanese entrants were all coming in under proper procedures, this statement of Pelayo's like the others, was "entirely groundless."

However, despite what seemed to him to be the obvious fallaciousness of Pelayo's "vicious propaganda," Consul Kaneko was wise enough to recognize that the so-called Japanese problem had become a focal point of nationwide attention in the Philippines. Accordingly, he prepared for the Foreign Office a memorandum in which he discussed possible countermeasures which he believed might appropriately be considered.98 Generally speaking, Kaneko wrote, there were two possibilities for dealing with this kind of accusatory attack. One was to pass over it in silence and to let the matter run its natural course, and the other was for the Japanese to intensify their efforts to "enlighten" the Filipinos. Kaneko admitted that the first alternative was attractive, taking into consideration the Filipino character. He also noted that in the past many problems which at first seemed to have aroused a great to-do were, when left alone, apparently forgotten. However, in this instance Consul Kaneko concluded that the second course was more advisable, and he proceeded to prescribe countermeasures which he believed should be taken in order to "enlighten" the Filipino public.

First of all, he proposed that well-known Filipino newspapermen from Manila be invited to Davao in order to try to provide the national press with a more accurate understanding, from the Japanese point of view, of the position of the Japanese in Davao. He hoped the Foreign Office would subscribe 1,500 pesos in order to pay the fares and expenses for such individuals. Next Kaneko recommended the printing and distribution of a "pamphlet" which would explain the Davao story from the Japanese point of view, and he also requested 500 pesos for the printing cost of such a brochure. Thirdly, he suggested the establishment of a Japan-Philippines Society to be patterned after the Japan Society in the United States and to carry out a program similar to that of the Japan Society. He noted that while such an association had been in the offing for a year or two, to date it had 
not materialized; but now that tourist parties of distinguished local residents were being sent to Japan, they might well be the nucleus of the society under discussion. Fourthly, Kaneko wrote that he himself intended to go to Manila and talk with newspapermen and influential politicians to clarify the real situation of the Japanese in Davao and to rectify misunderstandings. Finally, he urged that the attention of the Governor General, the Secretary of the Interior, and the Commander of the Constabulary be called to the necessity of checking those who spread vicious propaganda, particularly the rumors about the smuggling of weapons and ammunition, which might impede the friendly relations which then existed between Japan and the Philippines.

Consul Kaneko also stated that, since the Constitutional Convention was then taking up a number of proposals which affected the Japanese and was to enter its period of crucial decision-making in the latter part of November and the early part of December, it was important to expedite these matters as much as possible. Therefore, the Davao Acting Consul requested permission from the Foreign Minister to make an official trip to Manila for this purpose and said he would need 250 pesos as minimum expenses.

\section{Secretary Rodriguez Enters the Picture}

That Consul Kaneko's proposals were extremely timely was very evident when Eulogio Rodriguez, who had been appointed Secretary of Agriculture and Commerce on July 24, 1934, followed up the speech of Pelayo and the furor which it had occasioned by sending to investigate conditions in Davao in December, 1934, his brother Representative Julian Rodriguez, who had been elected to the Lower House from Davao. Further, on January 4, 1935, the Herald reported that at its next regular session the Philippine Legislature would discuss three plans to solve the "Japanese problem" in Davao. Two proposals to be offered for consideration to the House of Representatives by Representative Jose T. Surtida, Chairman of the Committee on 
Public Lands, were to purchase all lands and properties of the Japanese at Davao for P20,000,000 and to prohibit foreign laborers from working on public lands under lease. Secretary Rodriguez's brother, the aforementioned Representative Julian Rodriguez, said he would urge the rigid enforcement of the provisions of the acts governing public lands which prohibited the possession of public lands by foreigners other than Americans. And in response to the first recommendation of Representative Surtida, Consul General Kimura, in order to reinforce his public contention that the Japanese were in Davao only for economic reasons, said that a reasonable offer would be given sympathetic consideration. ${ }^{99}$

On January 7, 1935, Secretary Rodriguez sent to Davao a six-man committee of officials of his department under the chairmanship of Attorney Alfredo Fajardo of the Bureau of Lands. This group was instructed to obtain specific data about the extent and nature of the Japanese holdings there and to make recommendations accordingly. Then, during the first ten days of February, Secretary Rodriguez himself, accompanied by a party of fifteen persons, including the Undersecretary of Justice, the Chief of the Bureau of Lands, Senator Nolasco, and Governor Sevilla of Rizal Province, traveled to Davao in order to make a study at first hand of the role of the Japanese in the region. Stopping off at Zamboanga en route to Davao, the Secretary made public a plan to purchase all Japanese land holdings in Davao for the same amount, P20,000,000, which had been mentioned in the proposal of Representative Surtida. Such a move, said Rodriguez, would be the most "efficacious and expeditious" way of solving the whole Davao land question, and he believed that the Japanese, as stated previously by Consul General Kimura, would be agreeable. The Secretary recommended payment be made on a long term annual installment basis with the funds to be derived from the proceeds of the American processing tax, which, it had already been agreed, would be returned to the Philippines. ${ }^{100}$

On his arrival at Davao, Secretary Rodriguez held a series of discussions with provincial officials, prominent business figures, 
and leaders of the foreign community, including Consul Kaneko. Not unexpectedly, Kaneko told Rodriguez that the Japanese in Davao came there simply to make an honest living, that they had no ulterior motives, and that they did not intend to stay permanently in the province. Kaneko estimated the Japanese population in Davao at about 13,000 and claimed Japanese investments in the province to be worth between 40 and 50 million pesos. He also said that some 40,000 Filipinos were given employment by virtue of those investments. ${ }^{101}$ The most curious statement made by the Japanese official was that 4,000 Japanese had lost their lives pioneering in Davao and that 2,000 of those had been killed by wild tribesmen! ${ }^{102}$ Actually, according to constabulary records, between 1907 and 1934, 54 Japanese had been killed in Mindanao, 27 of those within the years since $1921 .{ }^{103}$ As one writer put it,

This is unfortunate, but at least it is not so bad as the alleged "2,000." Two thousand killed would indicate a minor war, and a war the government, at least, knows nothing about! If there were two thousand Japanese killed, how many lost their lives on the other side? Alas! As to this we are also in the dark!104

Perhaps more unexpected than the remarks of the Japanese consul was the reaction to Rodriguez's investigation on the part of the Filipinos at Davao. They were extremely uncooperative and consistently withheld information. When Secretary Rodriguez asked for suggestions to facilitate the preservation of public lands for Filipino use and to assist in the exclusion of aliens, only one person spoke out on the dummy problem, but so strong was Japanese influence that all of his fellow citizens joined in unanimous condemnation of him. ${ }^{105}$

However, by February 9, when the Rodriguez party left Davao, the Philippine press reported that the Secretary and Consul Kaneko had reached an agreement to "settle the Davao problem permanently." 106 As a preliminary step in that direction, Kaneko had proposed the calling of a round-table conference in Manila to include, in addition to all of the officials concerned, both Japanese and Filipino owners and officials of Japanese corporations and enterprises in Davao. With regard 
to the possible result of the first-hand inspection of Davao by Rodriguez himself, Consul Kaneko told the press, "I hope Secretary Rodriguez will hand down a fair decision. I admire his frankness in approaching a solution to the Davao question."'107

Moreover, Morokuma Yasaku, president and manager of the Ohta Development Company, traveled to Manila with Secretary Rodriguez aboard the government cutter Bustamente. Morokuma stated that in his view he could not see any reason for the proposed purchase of the Japanese holdings in Davao and thought that such a development could only be to the detriment of the economic prosperity of the area. Nevertheless, if the price were "reasonable," he said that he favored the sale because the Japanese could reinvest in Borneo. Added Morokuma:

It is unfair to accuse us of territorial designs. We are not a menace to the Philippines. We do not covet the Philippines. The Japanese government is not intervening and is not interested in any conflict. ${ }^{108}$

Of particular concern to the outcome of Secretary Rodriguez's inspection mission and of special importance to the Japanese was the attitude of Rodriguez himself. On this question there seemed to be some difference in the interpretations of Davao Consul Kaneko and Consul General Kimura. For Kaneko reported from Davao that while the Secretary was in that community between February 7 and February 9, his attitude was to try to maintain the status quo and to try to obstruct any further expansion of Japanese interests in the region. Such views, Kaneko believed, were evidenced by Rodriguez's public statements as well as by his having asked Kaneko himself at a private dinner party what the Japanese would do if lands which they had subleased were confiscated. ${ }^{109}$ Consul General Kimura, however, told the Foreign Office that he had paid a call on Acting Governor General Hayden, who had assured Kimura that before Rodriguez's departure for Davao, the Secretary had assured Hayden of his impartiality and denied any intention of threatening the position of the Japanese. Moreover, Kimura was disturbed lest the seeming belligerence of Kaneko toward the Rodriguez visit, as reported by the press, prejudice not only public opinion 
toward the Japanese but also Secretary Rodriguez, whom Kimura believed to be "sympathetic." 110

When Rodriguez returned to Manila on February 14, after a conference with Acting Governor General Hayden, the Secretary said that there seemed to be four possible solutions to the Davao problem:

1. Unconditional cancellation of illegally leased public lands.

2. Dissolution of subleasing with compensation for losses.

3. Legalization of subleases.

4. Cancellation of subleasing and permitting direct leases by Japanese. ${ }^{111}$

That the first of these four proposals was the one which was attracting the most interest within the Philippine government became increasingly evident during the next few days. On February 19, Consul General Kimura reported to Tokyo that at a party he had attended he had been informed that it had virtually been decided that officials who had taken advantage of their official position to lease land from the government and sublease it to others would be officially disciplined by having their original leases cancelled. However, in such cases it was said that the government would take the place of the lessor, would become the party to the contract, and would protect the rights and interests of those persons, i.e., Japanese, who were now farming such lands. Further, it was hoped that since such cancellations would be directed at the Filipino officials involved, the Japanese cultivators would exercise prudence and would remain calm so as not to create any unpleasantness between the two countries. ${ }^{112}$

At the same time Davao Consul Kaneko who was in Manila to further his "enlightenment" program met with Secretary Rodriguez. The latter told Kaneko that as a result of his investigation he intended to take drastic action in only a few cases of land held in the names of government officials. Rodriguez also said that he intended to recommend to Senate President Quezon and Acting Governor General Hayden that Japanese investments 
in such properties be fully protected and that in the forthcoming legislative session he would introduce a bill which would legally protect the vested interests of aliens on public lands. Moreover, Rodriguez indicated that he was most eager to avoid any clamorous controversy, for which Kaneko expressed his appreciation. ${ }^{113}$ Accordingly, both Kimura and Kaneko agreed in their report to the Foreign Office that, as a result of the current investigations, some Filipinos would lose their lands and there would undoubtedly be a considerable degree of turmoil. However, it was stressed that from the Japanese point of view it was unlikely that there would be any substantial loss. ${ }^{114}$

On February 19, Secretary Rodriguez made public the report of his personal investigation of the Davao problem. ${ }^{115}$ Among his conclusions was the statement that the Japanese now controlled 59,998.8659 hectares of land in Davao Province. Although there were $1,929,724$ hectares, including mountains and forests, in the province, according to Rodriguez, the Japanese lands constituted two-thirds of the whole cultivated area and encompassed the choicest agricultural lands. The report also stated that while the Japanese had not acquired any land by violence and had made real contributions to the economy of Davao, nevertheless under Philippine laws leases and subleases of public lands to Japanese by Filipinos were illegal and would have to be dealt with accordingly. ${ }^{116}$ As of December 31, 1934, Secretary Rodriguez estimated that there were 13,857 Japanese in Davao. His somewhat inflammatory conclusion was, therefore, that Davao was a rich province in the hands of the Japanese.

To meet the situation which had been "uncovered," the following remedies were proposed:

1. Immediately to suspend temporarily any action regarding public land concessions in Davao, Cotabato, Zamboanga, Sulu, and Lanao until the best method of the disposal of these lands could be found.

2. To exercise closer supervision over the issuance of pasture permits by the Bureau of Forestry and provisional permits for pasture purposes by the Bureau of Lands. 
3. To direct cadastral parties to go to Davao, Cotabato, Zamboanga, Sulu, and Lanao to subdivide public lands therein into small parcels which would be made available only to qualified applicants.

4. To cancel immediately or reject applications from government officials who were guilty of leasing or subleasing to Japanese or other aliens.

5. To cancel other illegal leases or subleases after a general study of all the contracts entered into had been undertaken.

6. To have the government plan a definite policy of not renewing land leases under Acts 2921 and 2975 when they expire. ${ }^{117}$

7. To require all notaries public to submit to the Secretary of Agriculture and Commerce a copy of all contracts executed by them affecting any lands in which the parties involved were aliens.

Having issued his report, the Secretary of Agriculture and Commerce proceeded to take measures to implement his plans to solve the Davao land problem. On March 7, with the purpose of preventing further violations of public land laws, Rodriguez promulgated two administrative orders. One of the orders provided for the sending of survey parties to make cadastral surveys of three districts of Davao where aliens resided. The purpose of this action was to try to delimit alien landholdings and to set aside all available remaining land for homesteaders. The second administrative decree set down a new code of rules governing the approval of applications for the granting of public lands and instructed the Director of the Bureau of Lands to hold up action on all pending applications or those which had been previously rejected until the cadastral surveys could be completed. Secretary Rodriguez also ordered the transfer of the best public lands officials of the Bureau of Lands to the provinces of Agusan, Cotabato, and Davao to enforce land laws properly. ${ }^{118}$ Moreover, in an exchange of letters the contents of which were made public, Acting Governor General Hayden and Secretary Rodriguez indicated their general agreement on Rodriguez's plans "to enforce 
public law and to retain the public patrimony for future generations."119 And on April 8, Hayden, in order to give the full support of his office for the Secretary's actions, revoked executive proclamation No. 67, s.1920, which had opened public lands in Agusan, Bukidnon, Cotabato, Lanao, and Zamboanga for disposition subject to future classification. ${ }^{120}$

\section{Japanese Countermoves}

Since the Japanese consular staff in the Islands as well as the local Japanese community had had every indication of the probable tenor of Rodriguez's report and of the possible actions that would follow its issuance, they were hardly unprepared for it. In fact, in line with the countermeasures that had been recommended by Consul Kaneko at the time of the Pelayo speech, a number of countermoves were already in progress. For example, under the aegis of Kaneko a "Davao Goodwill Tourist Party" had been organized for a trip to Japan. The party was described by the Davao Consul as consisting of relatively influential officials and private citizens of Davao, all of whom were said to be upper-class and members of the local intelligentsia. ${ }^{121}$ The tour leader was to be Antonio Habana, Jr., a former Assistant Provincial Fiscal and a law partner of Attorney Romualdo C. Quimpo, who was himself both a consulting lawyer of the Japanese Consulate in Davao and a local political leader. Significantly Habana's travel expenses were being donated by the Davao Japanese Cultivators Association and the Japanese Association of Davao. ${ }^{122}$

In his report to the Foreign Office on this proposed trip to Japan by Davao community leaders, Kaneko noted that the majority of the Filipinos living in Davao had contact, whether direct or indirect, with the economic or colonization activities of the local Japanese; and he felt that perhaps with only one or two exceptions, those Filipinos were pro-Japanese. However, according to Kaneko, if there were any narrow-mindedness or self-righteousness toward the Japanese among the local populace at Davao, it was his opinion that such misunderstandings re- 
sulted from their seeing what often appeared to be the "low grade life" led by immigrant colonists in the area.

Therefore, the Consul urged that the opportunity of the sightseeing party's coming to Japan be utilized to "deepen their understanding of Japanese culture and industry." He recommended they be provided with a guide by the Japan Tourist Bureau and that they be shown industrial installations, especially in the Tokyo and Osaka regions, military and naval facilities, schools, etc. Kaneko also asked that the party meet representatives of parent companies or related companies of Japanese enterprises which were operating in Davao, and he noted that Ohta Development Company, Furukawa Plantation Company, Mitsui Bussan, and Osaka Boeki had already agreed to make such arrangements. This kind of trip, concluded the Davao Consul, could be very helpful to the Japanese in the so-called Davao problem; and, since this was the first such trip from the area, he desired the "most striking results." 123

Another of Consul Kaneko's proposed countermeasures had been to invite influential newspapermen from Manila to Davao to "make them understand the real situation," and hopefully to counteract the "detrimental propaganda" about the Japanese which was then current in most of the Philippine press. ${ }^{124}$ When the plan received the approval of the Foreign Office, Kaneko consulted with the local Japanese entrepreneurs in Davao to sound out their reactions. While in general their feeling was that it might be a good idea, they felt that it would be wiser to watch the developing situation for a period of time before acting on this suggestion. Their reasoning was based on the fear that unfavorable reports might be published by such visiting newsmen since, in their view, "Filipinos generally cannot be trusted." 125 The Consul was obviously disgusted with the "stubbornly conservative" and negative policy of the business leaders, who, he believed, had lost ground in the past by what he termed their policy of "temporizing." 126

Kaneko's own opinion was that it would be much wiser to move at once to take the initiative and to invite carefully selected reporters to Davao in an inconspicuous manner. Moreover, he 
urged that simultaneously the consulate's consulting attorneys and other Filipinos who were close to the Japanese should maneuver in an appropriate fashion so that their influence might be brought to bear on whatever newspapermen might make the trip. It was Kaneko's belief that if the reporters' visits were carried out in that way, not only was there nothing to be worried about, but favorable results might be surely anticipated. So, on March 26, Kaneko reported to Tokyo that as the first experiment under the plan, it was decided to invite to Davao Modesto Farolan of the Herald. However, in consideration of the views of the Japanese business leaders in Davao, Farolan's visit was to be depicted to the public as one made on the initiative of the Herald. The Consulate General in Manila was to advance to Farolan on his departure for Davao 200 pesos for traveling expenses. Another 200 was to be given to him on his arrival as a fee for an advertisement in a special "Davao Supplement" of the Herald. ${ }^{127}$

The actual visit of Modesto Farolan to Davao came the following month when, accompanied by his son and a secretary, he stayed in Davao from April 28 until May 9. During his sojourn he was the guest of one of his relatives, a man named Narciso, who was Chief of the Intelligence Bureau of the local customs office. Farolan's trip was reported on in detail by Consul Kaneko to the Foreign Office, and as an insight into the inner workings of one aspect of Kaneko's “enlightenment" program, the account is most revealing. ${ }^{128}$

On the evening of his arrival in Davao, April 28, Farolan and Narciso were guests of Consul Kaneko at a small dinner party at which the president of the Japanese Association of Davao was also present. Farolan appeared to Kaneko to be afraid of publicity, and asked the Consul for only the usual conveniences during his visit and for help with publishing the Davao supplement. Farolan also suggested the 30th as the date of his next meeting with Kaneko, who gladly agreed, and at the same time invited Farolan to the evening reception on the night of the 29th in honor of the Emperor's birthday. 
Farolan's visit to the consulate on the morning of the 30th began with his complimenting Kaneko on the party of the night before, attended by some five hundred Japanese, Filipino, American, British, and Chinese nationals, and which, according to Farolan, was unprecedented even in Manila. Moreover, Farolan commented that he was surprised at the tremendous influence of the Japanese. Then, in so far as his own trip was concerned, he said that his purpose was justly and fairly to observe at first hand the so-called Davao Japanese problem from every angle and to report the results of his observations to the public through the press. He hoped that in so doing both the officials and the general citizenry might know the truth and that to this end he desired the assistance of the Davao Consulate. Concretely speaking, Farolan proposed to publish his findings in the D-M-H-M ${ }^{129}$ newspapers in three languages (English, Spanish and Tagalog) in a special 28or 32-page tabloid-style "Davao Supplement." Accordingly, he requested the assistance of Kaneko in securing sufficient advertising from Japanese firms in Davao to fill every other page with advertisements alone, in other words fourteen or sixteen full pages of advertising depending on the ultimate overall length of the supplement. The fees, he said, would be at the reduced rate of 90 pesos for one page or 1,440 pesos for the sixteen pages and 4,320 pesos for the publication of the 32 page supplement in the three languages or a slightly lower amount at the same 90 -peso-per-page rate for the fourteen pages of advertising in the three languages.

While Kaneko thanked Farolan very kindly for his intention to report his findings objectively, the Consul immediately decided that Farolan had really come to Davao to put the financial squeeze on the Japanese. Kaneko was very greatly surprised by the extent of what seemed to him to be almost extortionate demands to subsidize the publication of the proposed supplement. Of course, he was particularly disturbed because the specific plan for the invitations and the financing of newspaper reporters to come to Davao had been originally his; and, although Consul General Kimura had told him that Farolan was interested in 
some help in obtaining advertising, he had never imagined anything as grandiose as what Farolan had requested.

Therefore, in regard to Farolan's subsidized supplement proposition, Consul Kaneko told the Manila journalist that such an expenditure would be impossible for the Japanese at a time when there had been a disastrous decline in the price of hemp but that the Consul would consult with key business leaders in Davao and do his best to secure their support within the maximum possible limitations. Subsequently, Kaneko explained Farolan's desire to the leaders of the local Cultivators Association and of the Japanese Association and to other leading Japanese commercial and industrial personalities in Davao. They decided that they would collectively provide Farolan with a subsidy of 600 pesos for "traveling expenses" with no obligation insofar as the publication of the results of his trip was concerned. And, if it were absolutely unavoidable, they would agree to the publication of a 30-page supplement on Davao in the English-language Herald only and would buy advertising in it.

When Farolan heard about the subsidy offer, he rejected it on the grounds that it was likely to cause misunderstanding and that it would not help him to fulfill his duty to the D-M-H-M newspapers. The "unavoidable" offer was then made, accepted by Farolan, and reaffirmed on May 3, at a dinner given by Kaneko, at which all of the business leaders involved were present. At the time of his departure Farolan was given by the Davao Consul a total of 1,400 pesos, including 500 pesos jointly subscribed by the Cultivators Association and the Japanese Association. This sum was to subsidize both Farolan's personal travel expenses and the advertising charges for the English-language Davao supplement in the Herald. Kaneko felt that, all things considered, this kind of an expenditure in behalf of an "enlightening" project was well worth the money. He noted that Farolan himself was most grateful for the assistance and cooperation of the Japanese and seemed to be very much satisfied.

At the conclusion of his stay in Davao, Farolan also made known some of his conclusions in a private talk with Kaneko. The focus of the so-called Japanese problem in Davao, he said, 
was certainly the land problem and more specifically the labor or crop contract pakiaw system, which was in fact a form of sublease. Farolan personally thought that it would be a wise policy for the Philippine government not to tamper with the land question and to maintain the status quo. However, he believed that, since the government had undertaken such a large-scale investigation of the land situation, it was probably inevitable that in a few of the most flagrant cases of land-law violation, land might be confiscated, e.g., absentee landholders leasing land outright to the Japanese without any investment at all of their own. And he recommended that if this happened, the Japanese would be well advised not to fight the government's action but rather to trust the overall good intentions toward the Japanese of the Philippine government and to let the situation develop quietly. The implication of his remarks was that after a few initial dramatic steps in the most conspicuous cases, the whole matter would die a natural death. Farolan further assured Kaneko that the Philippine government was well aware that extreme solutions could only generate unpleasant problems abroad and serious complications at home.

Moreover, Farolan told the Davao Consul that he had found the various popular rumors about the Japanese, such as illegal entry of immigrants, smuggling of arms and ammunition, and fortification of strategic locations, to be utterly groundless and that he would so state in his article. He also said that he hoped the Davao supplement with his report as the core would be published by the end of May. This would provide sufficient time, he felt, to encourage the development in administration circles of opinion favorable to the Japanese before the return from Washington to Manila of Governor General Frank Murphy and Senate President Quezon, who would undoubtedly want to examine the whole question of the policy which should be adopted toward the Japanese in Davao. Farolan also told Kaneko that the Japanese could feel free to reprint the supplement and make use of it however they wished..$^{130}$

As a matter of fact, the results of Farolan's on-the-scene "independent survey" of the Japanese in Davao as ultimately pub- 
lished in the Herald's special supplement were so overwhelmingly favorable to the Japanese position that they were later put out in a separate volume, The Davao Problem, under Japanese sponsorship and bearing the "imprimatur" of the Davao Consul. In his report Farolan defended the landholding system in particular, calling the Japanese "contract developers" rather than sub-lessees, and urged that the Filipinos whose land was being developed be recognized as "patriotic" Filipinos rather than be condemned as "dummies." He praised the pakiaw system as a sensible method of opening new lands by means of employing Japanese energy, skill, labor, and capital, and asserted that the pakiaw was neither a sub-lease nor a violation of the statutory land laws. The Japanese, insisted Farolan, were not land-grabbers or law-breakers, and he recalled that as long ago as 1919, President Quezon himself in commenting on the attitude the government should take toward Japanese leases of public lands had said:

It is not necessary for us to take a hostile attitude against the Japanese. We owe it to the cause of friendly and harmonious relations with Japan that those who were caught when we closed our doors be allowed to enter .... the thing in its lowest term reduces itself to common courtesy. ${ }^{131}$

Farolan also noted that the American Governors-General had never done anything about Davao in the past nor had the Philippine Legislature, and he asked what new evidence had been brought to light which would now necessitate retroactive restrictive government action. After all, argued Farolan, the Japanese plantations were the most modern and progressive in Mindanao, and it was the Japanese who had given training to future Filipino settlers of virgin lands and who had opened up a profitable market for Philippine abaca, timber, and copra. Determined enemies of Japan were everywhere spreading fear and prejudice, Farolan concluded, but the people of the Philippines would not be misled. Support for Farolan's position came from ex-Representative Isidro Vamenta of Mindanao, who called the whole "Davao Question" a "tempest in a teapot" and praised Farolan's "dispassionate" study while severely criticizing "Japan-baiting." 132 


\section{Rodriguez Undaunted but not Unopposed}

Secretary Rodriguez, however, obviously unmoved by Farolan's report, continued undaunted on his original course. On June 20, 1935, he submitted a memorandum to Governor General Murphy calling for a number of specific actions to be taken which would directly affect only government officials and Filipino citizens and therefore could not, he believed, be misconstrued as anti-Japanese. Rodriguez proposed:

1. Cancellation or rejection of the leases or other applications of government officials who had been found guilty of leasing or subleasing their holdings without the consent of the Secretary of Agriculture and Commerce in violation of the law.

2. Rejection of the application of government officials who during their incumbency had taken advantage of their position in applying for public lands and in encumbering them or alienating them contrary to law.

3. Cancellation or rejection of the leases or applications of the wives of government officials.

4. Cancellation of the leases of such other persons as had been found to have leased or subleased their lands to third parties without the consent of the Secretary of the Department of Agriculture and Commerce. ${ }^{133}$

With the approval of the Governor-General these measures took effect at once and before June was over, 33 Filipino government officials with holdings of 3,600 hectares tenanted by 303 Japanese found their leases canceled. ${ }^{134}$

On June 24, 1935, Secretary Rodriguez ruled the pakiaw system illegal and in violation of Article 18 of the land law. In August, Attorney Alfredo Fajardo of the Bureau of Lands, acting under orders from Rodriguez, informed the Japanese settlers at Davao that illegal sub-leases were being canceled and that all improvements on such lands would be inventoried by the government so that appropriate compensation might be paid. Through September, Secretary Rodriguez had taken steps to cancel nearly two hundred ${ }^{135}$ applications of Philippine citizens on file in the Bureau of Lands for public lands in Davao which had been subleased by the applicants to Japanese in contravention of the land laws. Included among these were orders affecting provincial governors, mayors, fiscals, Army officers, officials 
of the insular government, prominent businessmen, and wives and relatives of all the preceding. ${ }^{136}$ The following was a typical example of a cancellation order:

L. A. No. 2859 (E-246)

PABLO LORENZO ${ }^{137}$

Applicant
Lot No. 783 Guianga Cadastre
Malagos, Guianga, Davao

\section{ORDER: CANCELLATION OF APPLICATION AND RESCISSION OF LEASE CONTRACT}

As the tract of land covered by Lease Application No. 2589 (E-246) of PABLO LORENZO is not occupied by the applicant himself but other persons who are deriving benefits therefrom in open violation of the law and in contravention of the following material statements made under oath by the applicant:

"In making this application for lease, I am not acting as agent for any person, corporation, organization or association to give them the benefits of the land entered, or any part thereof or the timber thereon, or the minerals therein, and I am not entering said land for the purpose of speculation but in good faith for my own exclusive benefit. I will not, directly or indirectly, make any agreement or contract, in any way or manner with any person or persons, corporation or association whatsoever, by which any right or rights which I may acquire from the government will or may inure in whole or in part to the benefit of any person, persons, corporation or association of persons. I will not sell, assign, transfer, sublet or in any manner encumber the land or the right or rights that I may acquire, without the approval of the Secretary of Agriculture and Natural Resources first had and obtained as provided in Section 37 of the Public Land Act No. 2874."

the application is hereby cancelled; the lease contract executed in connection herewith rescinded; and whatever amount has been paid on account thereof as all improvements existing thereon are hereby forfeited in favor of the government.

The District Land Officer, District No. 14, Bureau of Lands, Davao is hereby directed to take possession of the land and temporarily administer the same until it is applied for by and disposed of to other qualified applicants in accordance with law (Acts Nos. 2874, as amended and 3077) and the rules and regulations promulgated thereunder.

Manila, P.I., July 9, 1935

SIMEON RAMOS

APPROVED:

Director of Lands

EULOGIO RODRIGUEZ

Secretary of Agriculture and Commerce ${ }^{138}$

Vigorous and noisy protests from the Japanese in Davao began to be heard, and the Rodriguez lease cancellation program 
encountered stiffening opposition. At first the Japanese settlers hoped to resist these measures by having the Filipino leaseholders request court injunctions to prevent the Secretary of Agriculture from enforcing his cancellation decisions and at the same time asking the courts to determine the legality of the pakiaw system. However, many of the Filipino landholders seemed willing to have the former agreements canceled by the government so that the original leases might be renegotiated and the Japanese might be reemployed as farm laborers on much more favorable terms financially for the Filipinos.

Although the open opposition of the Japanese settlers at Davao to all of Secretary Rodriguez's restrictive measures was increasingly evident, the Japanese consular staff preferred to work behind the scenes as much as possible. Both Davao Consul Kaneko and Consul General Kimura were privately persuaded that much of the current apparently anti-Japanese actions of the Department of Agriculture and Commerce were principally motivated by domestic political considerations, by a desire to demonstrate convincingly to the Americans that the Philippine authorities were concerned about the pattern of Japanese settlement, or by personal rivalries or vendettas among Filipino politicians themselves. Obviously all of these possible reasons for tampering with the land situation among the Japanese involved very special Philippine problems which could hardly be discussed publicly. Therefore, of necessity the bulk of the efforts of the Japanese consular staff had to be directed at trying to convince both the settlers in Davao on the one hand and the Japanese government in Tokyo on the other hand not to become overly exercised because of certain overt manifestations which were really much more reflections of immediate and particular internal Philippine developments than of any serious or concerted antagonism toward Japanese interests in the Islands. At the same time it was incumbent on the consular staff to try to minimize the actual effects of Secretary Rodriguez's several newly issued administrative orders in order not to permit the generally friendly relations between Japan and the Philippines to be negatively affected. 
One overriding consideration for the Japanese consulate was the fact that the inauguration of the Philippine Commonwealth was scheduled for November 15. It was felt by the consular staff, and with much reason, that if the dispute over the enforcement of the lease cancellation orders and over the pakiaw system could be sustained on a quasi-legal basis until the onset of the Commonwealth administration, the chances for an ultimate solution not unfavorable to the Japanese were good. Evidence of this probability was often especially apparent in contacts between the Japanese and Senate President Quezon, who was to be the President of the Philippines under the Commonwealth government. As early as July, Secretary Rodriguez was submitting confidential reports to Quezon as to what his real intentions were, and Quezon in turn was reassuring the Japanese through talks with either his long time personal friend Morokuma or with Consul General Kimura. ${ }^{139}$

Quezon himself repeatedly indicated that it was his desire to have the whole issue settled as amicably as possible in order to eliminate controversial questions between Japan and the Philippines so that the new Commonwealth could enjoy both the friendship and trust of its neighbor. However, Quezon, who was in so many ways the consummate politician, was eager to begin his tenure in the presidency with as nearly unanimous popular support as he could get. Accordingly, he found very persuasive Rodriguez's argument that, if the present problem of the Japanese in Davao should remain unsolved, the opposition might use that issue in the forthcoming general election to attack him and the incumbent Nacionalista Party. Thus, while Quezon seemed to be reassuring the Japanese that after November 15, he would reexamine the whole question, he also seemed to be in agreement with Rodriguez that for the present at least a superficial impression should be given to the public that the lease cancellation orders were being carried out. ${ }^{140}$

Another subtle sign of the mitigation of Rodriguez's actions was passed along to the Japanese by officials of the Bureau of Lands. This was that an administrative decision of the Bureau gave affected owners of leased land a 60-day period of grace, 
during which they could request reinvestigation of lease cancellation orders. And, if, as was apparently being done, the leaseholders asked for that reinvestigation only a day or two before the 60-day period expired, the reinvestigation obviously would take time and the cancellation order could not take effect until its completion. Thus, the second decision of the Bureau of Lands could probably not be expected before the establishment of the Commonwealth and by that time it was very likely that there would be a change in the overall policy. It was also suggested to the Japanese that there might be a new Secretary of Agriculture and Commerce after November 15, in which case the entire situation would have to be restudied, and all previously issued cancellation orders would have to be suspended until the reexamination could be completed. ${ }^{141}$ Moreover, both Jose P. Laurel, the principal legal consultant to the Japanese, and Representative Felipe Buencamino, Jr., a longtime confidant of Quezon, gave the Japanese consulate every reason to believe that they could expect a significant improvement in the Davao situation after November $15 .{ }^{142}$

After the general election of 1935, and the victory of Quezon and his party, recently arrived Consul General Uchiyama Kiyoshi had an opportunity to talk with the President-elect and to try to clarify that official's possible future attitude toward the Davao problem. Quezon told Uchiyama that, although he had not yet really had time to study in detail the more recent developments in the situation or the legal basis of the various administrative orders involved, in any solution he would certainly give full consideration to the acquired rights and interests of the Japanese. Quezon also pointed out that since Secretary Rodriguez's actions had been taken with the approval of the Governor General, it would be a very "delicate" matter for Quezon to negotiate openly with the Japanese before he became President. As to the future, he assured the Consul General that he intended to study the whole problem very closely, particularly its legal aspects, but he said that it was too soon for him to suggest any possible specific proposals. Nevertheless, Quezon did mention that an understanding might be worked out between the Japanese cultivators 
and the government whereby the Japanese would pay the government whatever compensation had previously been paid to the leaseholders. ${ }^{143}$

After his talk with Quezon, Uchiyama told the Foreign Office that the main policy of the Japanese during the next few weeks prior to the President's inauguration should be to do nothing which would worsen the situation so as not to force the present administration toward harsher measures nor to compromise the future administration from the possibility of evolving somewhat more lenient policies. To this end he cautioned Davao Consul Kaneko that the Japanese residents in Davao should be restrained in their conduct and in their reactions to the moves of Secretary Rodriguez.

In addition, Uchiyama expressed to the Foreign Office his hope that the press in Japan would also exercise restraint in their reporting on the Davao situation. While calling Quezon "a very agreeable person," Uchiyama admitted that it was hard to place full confidence in his statements-apparently a nod to the political acumen of the President-elect. Nevertheless, the Consul General did believe that Quezon was sensitive to the potential seriousness of the Davao question in international relations and that therefore he would be sympathetic to the Japanese position "to a certain extent." ${ }^{144}$

However, despite the warnings of Uchiyama, on September $14,{ }^{145}$ a seven-hour mass meeting of the Japanese in Davao was held, and through Consul Kaneko a 700-word cablegram was sent to Tokyo demanding the assistance and support of the Japanese government. Secretary Rodriguez then announced that there would be no evictions until he had had an opportunity to hold further conferences with Japanese representatives. On September 16, Mr. Wajima Eiji of the Bureau of American Affairs of the Japanese Foreign Office arrived in Manila to investigate the Davao question, and the following day, September 17, the Japanese Association of Davao advised its 5,000 members to remain on their lands despite all interferences and obstacles. On September 19, Secretary Rodriguez, now seemingly on the defensive, reiterated that his cancellation orders were directed at 
Filipinos who were the lessees, not against the Japanese who were the sub-lessees. ${ }^{146}$ On October 1, support for this latter view of Rodriguez came from Governor General Murphy, who on that date met with a visiting delegation of ten members of Japan's House of Peers. Murphy told his callers that the Davao problem was basically a question of correcting the relationships between the government and the Filipino leaseholders. However, he carefully commented that he hoped that in the excitement the rights of the third party, namely the Japanese colonists, would be fully respected. ${ }^{147}$

\section{Solutions Galore}

Unfortunately the questions raised by the Davao land problem were not capable of simple solutions. For example, no one was really sure that the Japanese arrangements for working the land in Mindanao were in fact illegal. The Japanese had employed the best legal talent available from the beginning of their settlement in the Philippines in order to try to avoid exactly the kind of situation with which they were now confronted. It was Willard Price who so aptly termed the Japanese in the Philippines "lawyer-abiding." 148 The Japanese also could very justifiably ask why at this late date the Philippine government should suddenly try to rule their landholdings illegal when that same government had known for decades about leases and subleases and the pakiaw system in Davao. And what would happen if the leases were actually canceled? Would the American State Department permit such an obvious irritant to United StatesJapanese relations to be intensified still further? Could such a decision be enforced against the determined opposition of the Japanese settlers? Would the Japanese government stand idly by while its nationals were dispossessed from their homes? Or would the local indigenous inhabitants of Davao come to the assistance of the Japanese, as their previously demonstrated attitude had already indicated that they might, and pit Filipino against Filipino? What would be the effects of all of this on the Philippine economy, ${ }^{149}$ on the Philippine export trade, and on 
the future development of a peaceful, independent Philippine republic?

By mid-October, 1935, a number of suggestions for the resolution of the Davao land problem were emanating from various sources. One proposal appeared in a rather peculiar article entitled "DAVAO WHAT ABOUT IT?" in the radical journal Union. The author, after stating that the Japanese were in Davao to stay and that they would defend their holdings there to the end, recommended that the Philippines should follow the example of California and should pass strict alien land laws prohibiting aliens from owning real estate in the Islands. The logic of the proposal is dubious, because elsewhere in the same article the writer described how cleverly the Japanese in California had evaded the provisions of the alien land laws. Moreover, he pointed out that the Philippines could ill afford to antagonize Japan in the way that the United States had as a result of the California legislation. ${ }^{150}$

Two somewhat more feasible recommendations were reported by the Manila Tribune to be under discussion in official circles. One was to have the National Assembly pass an enabling act under which aliens could continue to cultivate and strip hemp on the lands now occupied by them with a share of the proceeds from the harvest to be paid to the Commonwealth government as a tax, instead of to the sublessors. The other proposal was that on any lands confiscated by the government under lease cancellation procedures just compensation be paid for the improvements made by the Japanese on such lands. The Japanese themselves estimated the total value of the improvements they had made on the Davao lands to be in the neighborhood of P30,000,000. ${ }^{151}$

A Japanese visitor to the Philippines, Mr. S. Hamano, a representative of the foreign news service of Nippon Dempo and a member of the East Asia Economic Research Bureau, made his own survey of the situation in Davao. He suggested that the Philippine government grant to all alien landholders a blanket extension of twenty-five years during which the lessees and sublessees could make their own readjustments. At any rate, said $\mathrm{Mr}$. 
Hamano, since the Japanese had already held the land in question for fifteen years, the right of possession demanded that they continue to hold the property. If this situation were interfered with, he again warned of "serious consequences." 152

When this latter remark appeared in the Manila press, the resultant outcry over what was termed Japan's threatening attitude toward the Philippine government ${ }^{153}$ greatly upset Consul General Uchiyama, who had been trying to "keep the lid on" as much as possible. Publicly Uchiyama stressed that Hamano spoke only for himself and did not represent the official view of the Japanese government, which had always sought to reach a constructive settlement of the Davao problem. Privately the Consul General was obviously deeply upset by Hamano's statement, and Uchiyama told the Foreign Office he intended to reprimand Hamano for his "rashness." 154

Immediately following the inauguration of the Commonwealth, Representative Felipe Buencamino said that he intended to introduce a bill which would bring about a full and final settlement of the Filipino-Japanese friction over the Davao land leases. His proposal was very simply to legalize all leases in the province as they then stood including those which the Secretary of Agriculture and Commerce had proposed to declare null and void. Representative Buencamino maintained that Americans and Filipinos were the ones who held the original leases anyway and that the Japanese who had sub-leases were the "innocent victims of circumstances." $155 \mathrm{He}$ also stated that the whole amount of land involved was only 150,000 acres and that the persons involved were small landowners since the large corporations had clear titles to their holdings. Therefore, said Buencamino, by validating all of the disputed Japanese sub-leases the new Commonwealth economy would be given a significant boost forward and friendly ties with the most powerful nation in the Orient would be assured. There were many in the Philippines who believed that this plan had the support of President Quezon because of its author, i.e., Buencamino. Perhaps more importantly many believed that this was also an "American plan" which had the support of the visiting Congressional delegates 
who had come to the Islands for the inauguration of the Commonwealth and of the State Department. This latter rationale was based on the view that in the United States, both Congress and the executive branch were eager to eliminate international complications in the Far East and to smooth the path for the infant Commonwealth regime. ${ }^{156}$

However, Secretary Rodriguez vehemently disagreed with the Buencamino proposal. Such a retrogressive step, said the Secretary, would be a cowardly act on the part of the new government in a clearcut matter of the enforcement of Philippine law. It would be highly inadvisable, he stated, to pass under pressure a new law clearly designed to benefit particular individuals and interests. If such action as Representative Buencamino proposed were taken, the Secretary argued, such a palpable demonstration of national weakness would in the long run be far more costly to the newly independent state than would any immediate prolongation of Philippine-Japanese tension. ${ }^{157}$ In support of his position Secretary Rodriguez had at hand "A Brief Statement of Some of the Important Facts about Davao and the Present Davao Land Problem in Connection with Japanese Land Holdings." This was a report dated November 20, 1935 , compiled and submitted by a committee appointed by the Secretary of Agriculture and Commerce, to execute the orders cancelling and rejecting illegal land holdings in Davao. ${ }^{158}$

The report began with a statistical survey of Japanese population, investments and land holdings in Davao. Then it described Secretary Rodriguez's order canceling leases or rejecting applications in violation of laws governing public lands. The reactions and protests of the Japanese community were duly recorded, and on the final two pages the committee presented its own summary of the entire problem. The group stated that the Japanese being excellent businessmen controlled the agriculture, commerce, and industry of Davao Province and that they were sending out of the Philippines money that ought to be circulating in the Islands. The committee further concluded that Japan's unique traditions, religion, and history would always differentiate the Japanese from their Filipino neighbors and 
that the Japanese in the Islands were intensely nationalistic and could, in the committee's words, "never become Filipinos." Finally, the report offered the opinion that the Japanese foothold in Davao was now too solidly entrenched for the Japanese to give up and that Davao would therefore be a strategic threat in any possible future conflict between the United States and Japan.

However, despite the contentious tone of this report, first behind the scenes and then publicly, as had been earlier predicted by the Japanese consular staff, the Davao situation did begin to undergo a change following the inauguration of Quezon as President of the Commonwealth in his own right. For on November 25, 1935, Consul General Uchiyama was able to inform the Foreign Office that on the 24th, Quezon had held a talk with Laurel, whom the new chief executive had invited to join his cabinet. Laurel in turn told Uchiyama that the two men had discussed the subject of Davao and that Quezon had told Laurel that as of the 24th, the President had secretly ordered Secretary Rodriguez to cease all administrative actions with regard to Davao and that Quezon himself planned a visit to Davao the following year for a first hand inspection of the situation. ${ }^{159}$

Apparently influenced by the changed atmosphere in the administration now that President Quezon was in full command, a seemingly more moderate Secretary Rodriguez addressed a letter to the Japanese Association of Davao, requesting their cooperation in finding a solution to the land question. On December 3, Taguma Torataro, president of the Association, replied to the Secretary by expressing his willingness to cooperate but with the suggestion that before any action be taken by the Commonwealth Government, it would be proper for the appropriate authorities to hear the testimony of the Japanese settlers in Davao Province. Apparently recognizing that his efforts to cancel illegal land holdings were being frustrated by the determined opposition of the Japanese at Davao as well as by the diplomatic efforts of the Japanese consular officials in both Manila and Davao and desiring to end the controversy as quickly and as equitably as possible, Secretary Rodriguez on January 2, 1936, 
formally requested President Quezon to define the policies which the Department of Agriculture and Commerce was to follow. ${ }^{160}$

Up to that date the Secretary had been acting in accordance with decisions taken and guide lines established under the administration of former Governor-General Murphy. In view of the stalemate which prevailed between the authorities in Manila and the Japanese settlers, it now seemed, therefore, both necessary and correct for Rodriguez to ask the new Commonwealth President to provide new policy directives covering the situation at Davao. At the end of January President Quezon in his first public official action with regard to Davao set aside 4,652 hectares of public land in Kapalong, Taguin, Davao Province, as withdrawn from settlement until a decision could be reached on what the government's program was to be.

Meanwhile, the Japanese Consulate was continuing to bring pressure behind the scenes, and on February 6, Consul General Uchiyama in a lengthy report to Tokyo described certain confidences exchanged with Jose P. Laurel. ${ }^{161}$ Laurel had told the Japanese Consul General that he was being considered for an important government post, either as legal adviser to the President or as Secretary of Justice or as a Supreme Court Justice. Laurel feared that if he rejected any of these posts his critics would say that he had no need of them since he was being so well rewarded by the Japanese for his efforts in their behalf on the Davao question. Uchiyama told Laurel that the Japanese preferred him in the position of legal adviser to the President, but Laurel replied that he was too old to "be a bellboy," that there was presently no vacancy in the position of Secretary of Justice, and that if he turned down the Supreme Court post the Davao question would be adversely affected. Commented Uchiyama:

There is some doubt in my mind as to whether or not he is seeking to run out on us because of the difficulty of getting a fundamental settlement of the Davao question. But we cannot do anything about the fact that he is a Filipino.162

Quickly and with the help of Laurel the Japanese sought another equally cooperative Filipino attorney-politician who would do their bidding for reasonable financial reward. All 
parties agreed to the selection of Laurel's law partner, Assemblyman Pedro Sabido, who was considered an influential figure in the Philippine Assembly; and on February 6, Laurel came to the Japanese consulate to say that he had agreed to accept membership on the Supreme Court, though he would also from time to time act in a private capacity as Quezon's legal adviser. Accordingly Uchiyama reported to Tokyo:

So he [Laurel] will still have the opportunity to give proper advice to the President on the Davao question. But in view of the fact that he will be a judicial official he will not be able to enter into arrangements which would result in his receiving monetary payments from the outside. So far as his arrangement with this office is concerned, I intend to arrive at a convenient arrangement after consulting with him further. ${ }^{163}$

Uchiyama also recommended to the Foreign Office that no decision on the legality of the pakiaw system be pressed as long as the cancellation orders were not enforced.

In a subsequent dispatch to Tokyo, Uchiyama said that the Davao land question was being completely turned over by the consulate to Sabido, who was being given 2,000 pesos for the present and would be paid 10,000 pesos when the Davao problem was settled satisfactorily. ${ }^{164}$ Sabido had told Uchiyama that there had been some objection to Laurel's Supreme Court appointment because of his reportedly pro-Japanese sentiments but that President Quezon had no objection to making appointments of men who were pro-Japanese. Interestingly, in his dispatch Uchiyama did not accept Sabido's interpretation but rather took the position that the appointment of Laurel was a politically astute move by Quezon designed to pacify one of his more articulate critics. ${ }^{165}$

\section{Quezon Takes Charge}

Finally on February 12, 1936, almost one year after the issuance of his first report on illegal land tenure in Davao, Secretary Rodriguez announced publicly that the whole problem was now in the hands of President Quezon, who would study the situation himself and would make known his decision in due time. The transference of jurisdiction from the Secretary of 
Agriculture and Commerce to the President immediately eased the existing tensions. In the first place, the very center of the entire controversy, Secretary Rodriguez, was now, in effect, removed from the scene. Secondly, the problem would now be handled at the highest level, and President Quezon had the confidence and trust of the Japanese in the Philippines as well as the good will of the Japanese government, which was eager to establish close and friendly relations with the new Philippine Commonwealth. Thirdly, the statement that the President would "study" the Davao question was politically and diplomatically extremely astute. Clearly, any study, especially a presidential study, implies care, depth, and above all time, which realistically in this case meant an indefinite postponement of any enforcement of the earlier lease cancellation orders and thus a general calming of a potentially disruptive situation.

By late February the passage of time had already begun to permit better perspective to be brought to bear on the Davao problem. This was evident in a general overview of the situation which the recently hired Pedro Sabido reported to Vice Consul Kihara Jitaro. ${ }^{166}$ Sabido pointed out that most influential voices in the Commonwealth agreed that the Philippines must maintain friendly relations with Japan in the light of the Asian origins of both peoples, the forthcoming independence of the Islands, and the desire for peace in the Far East. However, Sabido said that emerging Filipino nationalism, American antiJapanese propaganda, and the Manchurian Incident had all contributed to a Japanophobia which caused many individuals to misunderstand the Japanese colonization in Davao as having political rather than simply economic significance. Therefore, it was Sabido's view that the Japanese themselves had reached, in effect, a time for decision, i.e., whether to hold on to, develop fully and protect their present holdings, or to plan for future expansion.

Sabido further indicated that it was his belief a solution of the Davao land problem satisfactory to the Japanese could not be expected either from the Philippine courts or through the National Assembly, since both the judicial and legislative branches 
of the Commonwealth government, in Sabido's view, would be subject to the then current anti-Japanese tendency of public opinion. The advice of Sabido was that the Japanese could probably anticipate a much more equitable resolution of the issue from the executive branch, despite the previous antipathy of the Secretary of Agriculture and Commerce, and in particular from President Quezon. Perhaps, however, some six or seven years hence, when independence was secure and economic difficulties would have worsened, and the "enlightenment" program of the Japanese would have taken effect, then it might be relatively easy, thought Sabido, to have the Assembly legalize the pakiaw system or to take some other legislative action which would affirm the right of the Japanese to cultivate land at Davao without interference.

Therefore, for the present it seemed likely to Sabido that the Japanese could expect the President to follow a solution which might immediately cause the Japanese to lose a few subleases, through the carrying out of cancellation procedures, and to have to suspend any further extension of their land holdings for the next few years. However, this result, according to Sabido, would be for the Japanese to "gain a big thing by sacrificing a small thing," as he put it. For by carrying out a few cancellations as proposed, the face of the President, Secretary Rodriguez, and the Commonwealth government both at home and abroad would be saved and the overall interests of the Japanese in Davao would be sustained. Sabido also recommended, and the consulate agreed, that this probable solution should be kept secret for the time being and should not be disclosed particularly to the settlers in Davao in view of their hostility as well as their volatility.

Consul General Uchiyama, after reporting these views of Sabido, told the Foreign Office that he intended to see the President once more to point out to him the facts of the Japanese contribution to the development of Davao and to stress the urgency of a harmonious solution to the problem there both from the standpoint of Philippine policy toward Japan and from the standpoint of basic morality. In addition, Vice Consul Kihara 
sought out the views of Sergio Osmena and Manuel Roxas, since the Japanese consular staff in Manila believed the next President of the Philippines would be either one or the other. Both men stressed the necessity of Philippine-Japanese amity and assured Kihara that they would support a solution worked out by the Japanese consulate. ${ }^{167}$

As he had promised Consul General Uchiyama as early as November 7, 1935, ${ }^{168}$ in April, 1936, President Quezon made a personal inspection tour of the Japanese lands in Davao and met with leading personalities of the province, both Filipino and Japanese. On his trip the President was accompanied by his Secretaries of Agriculture and Commerce (Rodriguez); Interior (Elpidio Quirino); and Justice (Jose Yulo); the Director of Prisons, Colonel Paulino Santos; the Director of the Bureau of Non-Christian Tribes, Teopisto Guingona; former Secretary of Finance, Miguel Unson; ex-Senator Jose Generoso, assistant legal adviser to the President; Captain Bonner Fellers, aide-de-camp to Quezon; and key members of the National Assembly, including Assemblyman Sabido, who was identified in the press as counsel for "those affected." 169 Also in the presidential party were Consul General Uchiyama and the President's good friend Morokuma Yasaku of the Ohta Development Company.

Even before the President reached Davao, Sabido who had accompanied the party en route south from Manila returned to Manila, ostensibly to prepare certain documents. However, he reported in full to Vice Consul Kihara what his impressions were of Quezon's present attitude on the basis of several conversations during the voyage. ${ }^{170}$ First of all, Sabido told Kihara that the President did not intend to solve the Davao problem at that time but that his tour was part of his previously announced "study," which would ultimately result in his "decision." Sabido also noted that the President's being accompanied by his personal legal adviser Jose Generoso was a gesture to the Japanese, who were suspicious of Secretary of Justice Yulo as being prejudiced against them, and that after the presidential party left Davao, Generoso would remain an additional two weeks to make a thorough investigation of the legal situation. According to what 
Quezon had told him, Sabido was also able to assure Kihara that, while the President felt that Filipinos who had violated the land laws should be punished, neither the rights nor the interests of Filipinos who had observed the laws or of Japanese cultivators would be in any way affected. Moreover, Quezon had also told Sabido that all of the pakiaw contracts then in effect should be allowed to run their course, although he had not indicated whether or not he favored renewals of those that had already expired or were about to expire. It was still Sabido's considered opinion that, if necessary, expired contracts, which were relatively few in number, should be let go by the boards by the Japanese as long as those still in effect would be permitted to stand. This was another facet of his plan to "gain a big thing by sacrificing a small thing."

Sabido also advised Kihara that, as soon as the President arrived in Davao, Quezon intended to hear the views on separate occasions of both Filipinos and Japanese who were concerned with the land question. Therefore, Sabido suggested that those Filipinos who were heard should be "oriented in a direction which will be advantageous to us." 171 Further, he urged that those Japanese who appeared before the President strongly assert that the objective of the Japanese in Davao was merely cultivation rather than permanent possession of land and that, since in the past the government had never interfered with the pakiaw system, any precipitate action to cancel such contracts now would be extremely unfair. In fact, Sabido proposed that the Japanese request a uniform extension of all such contracts for a period of approximately ten years. His reasoning was that each contract had a different expiration date, and thus each time a contract expired a new crisis was liable to occur. If such a uniform extension could be arranged, Sabido thought that at the end of ten years the possibility for maneuvers favorable to the Japanese in a fully independent Philippines would be far better than at the present time. In short, it was Sabido's idea that the Japanese position would be far stronger if it were presented in the broadest terms with the emphasis on their general situation rather than if it were argued on the basis of individual cases. ${ }^{172}$ 
All in all, Sabido's report on the views of President Quezon agreed with what Consul General Uchiyama had been able to glean from his personal talks with the President and with the tenor of reports appearing in the Philippine press. The belief that had been adhered to by the Japanese consular staff throughout the preceding year, namely that after the inauguration of the Commonwealth the Davao situation would be significantly improved and that Quezon himself would be willing and eager to improve relations with Japan, certainly seemed to have been justified. At the very moment of the President's visit to Davao, for example, the press stated that, since there was an earnest desire for settlement of the problem on both sides, a compromise settlement was believed almost certain. Moreover, according to one Manila daily, while the basic intention of the administration was to preserve the Philippine patrimony at Davao, Quezon's ability to "grasp any situation" anticipated a "happy settlement." 173 In fact, so improved had the atmosphere become as a result of the President's personal intervention that after a conference with Morokuma and the Japanese Consuls, Quezon could jokingly say: "I have already sworn allegiance to the Japanese Emperor." "174 Consul General Uchiyama too was quoted as saying: "There is nothing in the world that cannot be solved by friendship and good understanding. Banish fear and suspicion, and everything will be all right." 175

After a round of whirlwind tours, conferences, speeches, and banquets at Davao, President Quezon and his party returned to Manila without announcing any solution of what some observers called the first crucial test of his presidential statesmanship. How well the President was to pass this test began to be evident in a press conference held shortly after his return to the capital:

THE PRESS: Mr. President, will you please tell us something about the Davao question?

THE PRESIDENT: Well, gentlemen, first of all, nothing about that Davao question, that is, no steps will be taken without first consulting with the Legislature; second, every case here has been considered in its own merit. We have to be sure of the facts and the circumstances attending the case before we can decide what can be done in every single case. Now there seems to be, or there has been an idea prevalent among the 
people that if the Secretary of Agriculture found that the terms of a lease have been violated the government can take the lot. It is not so. Even in the case where there is a clear violation of the terms of the lease, the power of the Executive Department of Government does not go any further than to declare that lease terminated. If the man in possession of the land refuses to give back the land to the government, the government would have to go to courts and let the courts determine whether the lease or the terms of the contract have been broken. This idea that any time that Rodriguez said, "You have broken the terms of the lease, and therefore, I take the land" is not true. Even if a tenant is not willing to get out of the land, the government can not use force, for it is uncivilized to use force. You can not take possession of anything by force. You can not dispossess anybody by force who is in actual possession of a real movable property; you can only dispossess him of his property by decree of the court. Now after the court has decreed, then the Executive Department will have to execute the decision of the court. If you will let me explain further, you can call a police and say you want to dispossess a certain person who is in possession of your house. That person can stay there even for a month, and yet you can not dispossess him or drive him away. You have to go to the courts. I think that that is the law, otherwise people in possession of real or movable property can not be deprived of their possession by the government.

THE PRESS: Is there any refusal to renew any lease that has expired?

THE PRESIDENT: There is no lease that has expired.

THE PRESS: So that the government should ask authorization from the Legislature as to the cancellation of the lease?

THE PRESIDENT: Yes, or the authorization of the courts.

THE PRESS: Mr. President, if you go to Japan, would you discuss the Davao case with the Japanese government?

THE PRESIDENT: No, as a matter of fact, there is nothing to be discussed between this government and the Japanese Government. There are Japanese nationals that are being involved and I want the consul to know and to assure him that the Government of this Commonwealth is not going to act arbitrarily in handling this question. The Government of Japan is not involved there.

THE PRESS: Is there anything that the Government of the Commonwealth has taken as to this Davao question?

THE PRESIDENT: Nothing has been done as yet. Some time ago I told the Secretary of Agriculture to suspend any action on the matter, until something more is found out as to the real situation; so there is no lease that has been cancelled. You know the Department of Agriculture has been informed that the terms of the contract have been violated; that the Department is cancelling the contract, and therefore the Department demands that the government be given possession of the land. If the party concerned does not wish to do it and denies that the terms of the contract have been violated, then the courts will have to decide whether the terms of the contract have been violated or not, basing on the facts that may be proven in court. 
There are many things said about this Davao situation. In fact, certain statements and information regarding the Davao situation that have been printed in the papers are not exactly true. Somebody has been talking loose somewhere or statements have been placed in their mouth. I have been quoted for having said, "The Japanese Consul can not bluff me." Why, anybody who has a common sense can see that that is not the proper language to use. ${ }^{176}$

Clearly these remarks by the Philippine President were designed to becalm still further the turbulence that had been surrounding the Davao land question ever since the appointment of Eulogio Rodriguez to the office of Secretary of Agriculture and Commerce. It is also worthy of note that practically simultaneously with Quezon's press conference statements Consul General Uchiyama had a reassuring conversation with United States High Commissioner Frank Murphy, who told Uchiyama that from the beginning the American government had wanted to avoid any disputes among Japan, the Philippines, and the United States over Davao. Murphy said that the existing interests of the Japanese should be respected and that expiring leases should be permitted to be renewed under appropriate conditions. Moreover, the American High Commissioner told the Consul General that, while he did not want to interfere in Philippine internal matters, since that was an issue of great importance to United States-Japanese friendship, he would work for an equitable solution by expressing Uchiyama's views to Quezon the next time he talked with him. ${ }^{17 \tau}$

On May 11, President Quezon gave a dinner for some forty members of the Philippine National Assembly. Pedro Sabido, who was present, later told the Japanese Consul General that he had held the floor for some two and a half hours, presenting a series of points on the subject of Davao. Sabido reportedly told his listeners that in the future the Philippines could not rely solely on America in politics or economics, especially in view of the unsympathetic attitude of the American Congress in regard to Philippine sugar and coconut oil. Thus, he suggested, the Islands would be well advised to develop friendly relations with Japan, particularly through economic cooperation and specifically by means of the protection of Japanese interests in 
Davao, the development of which had been such a boon to the Philippine economy. Sabido said that he had also decried attempts to link the Manchurian problem to developments in Davao and that he had described Japan's actions in Manchuria as a magnanimous effort to sustain the independence of that unhappy land. According to Sabido, President Quezon listened attentively to this discourse and said that Sabido's views should be given careful consideration. ${ }^{178}$

Just a little over a month later, Sabido told the Japanese that he had been consulted by Quezon in the preparation of remarks on the subject of Davao, which the President intended to include in his message to the First National Assembly. Sabido predicted that, in a speech which only President Quezon was powerful enough to make, he would indirectly warn the Philippine legislators not to discuss the Davao question any further. ${ }^{179}$ The accuracy of Sabido's prediction seemed to be born out when on June 23, 1936, before the Assembly Quezon discussed Davao as follows:

Much has been printed in the local press and foreign papers regarding the ownership of large tracts of land by Japanese subjects in Davao. There is an impression that Davao is actually owned by the Japanese. Such is not the case.

The total area owned, leased and/or cultivated by the Japanese in Davao is about sixty thousand hectares out of almost two million hectares that constitutes the total area of the Public Domain in that Province. It is true that Japanese investments in Davao are considerable, and that there are doubts expressed as to the legality of some of the transactions entered into between Filipinos and Japanese regarding the Public Domain leased to Filipinos by the Government. In these cases the Government will act in accordance with law and equity. Before any course of action is finally decided upon by the Administration, I shall advise with the Assembly and take no steps without your previous knowledge. There is nothing in the so-called Davao problem that should cause serious concern. ${ }^{180}$

It was the last sentence which was of particular importance, for critics of the President claimed consistently that he had said, "There is no Davao problem," a statement which, as far as can be ascertained, he never made. ${ }^{181}$ What he had said at Davao in April in the course of his inspection tour was that there was no problem which with good will and determination on both 
sides could not be solved, a remark calculated to lessen the passions that had been aroused during the debates of the preceding year. The same purpose and desire were once more evident in his very temperate and carefully considered remarks to the $\mathrm{Na}$ tional Assembly previously quoted. Nor did President Quezon mean to convey that, although there was nothing in the situation at Davao which "should cause serious concern," he intended to refrain from taking whatever action he felt to be necessary. Inaction since February, the Presidential trip, friendly contacts with Japanese officials, and now the moderate words of the message to the Assembly had all served the end of greatly relaxing the highly charged atmosphere which the President had inherited at the beginning of his administration. He was now ready to recommend positive steps in order to ameliorate a situation which he himself undoubtedly recognized as a possible future source of potential danger to a free Philippines.

In that same message to the First National Assembly President Quezon also had said:

A vast and rich territory with untapped natural resources is a temptation to enterprising nations that are looking for an outlet for their excess populations. While no nation has the right to violate the territorial integrity of another nation, people that lack the energy, ability or desire to make use of the resources which Divine Providence has placed in their hands, afford an excuse for a more energetic and willful people to deprive them of their lawful heritage. If, therefore, we are resolved to conserve Mindanao for ourselves and our posterity, we must bend all our efforts to occupy and develop it and guard it against avarice and greed. . . . The members of this Assembly, especially those who visited Mindanao recently with me, are conscious, I feel sure, of our grave responsibility to encourage settlement and develop Mindanao. . . . I invite you therefore, to give this matter preferential consideration ...182

In other words, what the President was recommending as a positive solution to the vexing problem of Japanese penetration of Mindanao was a concerted program to bring about the development of the remainder of the island by the Filipinos themselves in order to prevent the further alienation of public lands by foreigners of any nationality. He was in fact suggesting that the Davao problem might best be solved by simply confining the Japanese to the area in Davao Province which they then held, 
by surrounding the lands under their control with lands cultivated by Filipinos, and by covering the remainder of the island of Mindanao with government-supported colonization projects.

Under the direction and leadership of President Quezon, a National Land Settlement Administration was established with the purpose of assisting Filipino migrants to move from heavily populated areas to new lands in Davao, Cotabato, and Lanao provinces. ${ }^{183}$ Of equal importance with the creation of new agricultural settlements was the building of new roads which would serve first to attract laborers for their construction and then to provide arteries of comunication to facilitate the movement of new settlers into hitherto unoccupied and uncultivated regions. Originally, in line with the President's recommendations, government funds were made available for long-term loans to would-be homesteaders to encourage them to move from overcrowded sections of Luzon, Cebu, etc. However, once the program was started in earnest, voluntary migration was so heavy and so rapid that those funds could be applied to other projects such as road building.

Whether or not in the long run this solution would have worked (and there are many who doubt it) will remain forever a moot question, since the Davao situation had changed relatively little when war broke out in December, 1941. But in retrospect the diplomacy and statesmanship exercised by President Quezon, with the tacit support of the American government, seem most impressive. As in so many difficult governmental decisions both past and present, those on the outside, including on the one hand the Japanese settlers and their Filipino advocates such as Sabido and on the other hand a small but vocal group of anti-Japanese Filipinos both in and out of the Assembly, demanded resolute and unflinching decisions. However, such decisions would in this particular instance either have confirmed the Japanese in their holdings or in quite the opposite fashion would have, if necessary, forcibly ejected the Japanese from lands which they were said to hold illegally. But President Quezon for his part recognized that the question of Davao was a very delicate one with many more ramifications than either 
his critics or perhaps even the industrious Secretary Rodriguez realized. Therefore, his original procrastination, his personal trip to the area, and his minimizing of the problem in speaking to the National Assembly were all directed toward an ultimate solution which could immediately offend none of the parties involved in the controversy but which might in the end retain the rich heritage of Mindanao for the Filipinos themselves.

Despite these astute tactics, however, Quezon's efforts were undoubtedly made more difficult by the almost exclusive ethnic communalism and cultural isolation which characterized Japanese life at Davao. Other than the marriages of convenience contracted between some Japanese males and some Bagobo tribeswomen, there were few Filipino-Japanese unions, and Filipino-Japanese mestizos were rarely seen. The Japanese Association of Davao was the very heart of Davao community life and was unquestionably far more meaningful to every Japanese in Davao than any organ of the Philippine government. In fact, as the Japanese settlers discovered with marked frequency the "pliability" of all levels of Filipino officialdom, disdain for Philippine authority increased; and the role of the Japanese Association became quasi-governmental. It was the Association which was directly concerned with the economic and social well being of the Japanese colony. It was the Association, too, which through its efforts sustained all of the traditional Japanese cultural patterns and habits and a full Japanese social life so that being in Davao would be little different from being back home. Among the most successful of its undertakings was the maintenance of Japanese schools run along Japanese lines and staffed by a faculty of imported Japanese teachers.

The Japanese in Davao received their information from two Japanese-language daily newspapers, one of them published in Manila, and had a number of Japanese-language bulletins and magazines also available to them. Shinto and Buddhist religious functionaries were on hand to fill roles identical with those they performed in the homeland. Physicians, veterinarians, technicians, and craftsmen were all Japanese. One could, if one were a Japanese at Davao, literally live for weeks or months without 
having any contact with Filipinos at all, except for common laborers or perhaps a Filipino attorney, who might well be serving as a dummy. In fact it is difficult to determine what, if any, Philippine customs, practices, or traits were acquired by the Japanese. ${ }^{184}$ As Professor Cody has stated in describing the Japanese community at Davao, "In their homes, schools, newspapers, and in spirit the retention of national identity remained firm." 185

Thus, the mollifying endeavors of President Quezon encountered both the frequent volatility and communal exclusiveness of the Japanese settlers in Davao and the suspicion with which the Philippine public increasingly regarded their selfisolated Japanese neighbors. Moreover, the pressures of Japanese expansionism on the mainland of Asia also contributed in the late 1930's to a more widely articulated Filipino view of the Davao region as a "Little Japan" or "Davaokuo." Interestingly, the Japanese diplomatic establishment in the Philippines, in working with the Commonwealth administration toward a mutually satisfactory resolution of the Davao question, faced the same problems. For the local consular staff spent much of its time trying to mitigate the frequently inflamed passions of the Japanese at Davao in order to try to head off anticipated outraged reactions among the general public of the Islands. In addition, these officials were simultaneously attempting to provide that same public with rationales for acts of Japanese aggression, acts which the Consulate General ordinarily learned about after the fact through the press. ${ }^{186}$ Therefore, the parallel interests of the Quezon regime and of the Japanese consular corps tended to bring the two closer together and to sustain a felicitous climate of Japanese-Philippine relations despite the increasing tensions which characterized Japanese-American affairs.

\section{Davao: On an Even Keel}

From mid-1936 through the spring of 1939, the persistent and careful actions of both the Philippine and Japanese governments to ease the Davao situation continued to bear fruit. Although during those years there were a number of developments 
which affected the Japanese settlement in Davao, none of them proved detrimental. In fact, certain events contributed importantly to the relative stabilization of Japanese-Philippine relations.

In this latter regard, one of the most significant occurrences was the passage by the National Assembly of a new public land law (Commonwealth Act No. 141, approved November 7, 1936) which was to replace the collectanea of the frequently amended public land law of 1919. While this bill was being discussed in committee, Pedro Sabido, who was himself a member of the Assembly's Committee on Public Lands, kept in close touch with the Japanese consulate, which was naturally concerned. It was Sabido's view that the proposed revisions contained in the new law were simply to try to bring the legislation covering public lands more into conformity with the Constitution and that there was no special connection between the new law and the Davao situation.

However, Sabido did express his concern to Consul General Uchiyama that in going over possible revisions, committee members were being given an opportunity to "play with all sorts of words and phrases" which might open up the whole Pandora's box of leased lands. Therefore, it was Sabido's opinion that Japanese pressure should be focused on the prevention of the reopening of the question of the pakiaw system's legality. ${ }^{187}$ This was, according to Sabido, especially important because Secretary of Agriculture and Commerce Rodriguez had long since said that the pakiaw system was illegal. Although, as a result of the tactics of President Quezon, a certain ambiguity still surrounded Rodriguez's interpretation, if the issue ever came before the Assembly directly, Sabido was sure that the Assembly would support the Secretary. ${ }^{188}$ Thus, when the new public land law was passed, while Article 40 dealt with the limitations on the transfer of the rights of leaseholders of public lands, the pakiaw system as such was not specifically mentioned.

Moreover, as Sabido had always advised and Consul General Uchiyama had agreed, the Davao situation continued to be handled by the executive branch of the Philippine government; 
of major concern to the Japanese was the identity of the individual officials who held key positions affecting Davao. The personality who continued to be looked upon by the consulate as their principal "adversary" was, of course, Secretary Rodriguez. In January of 1937, Assemblyman Benigno S. Aquino secretly confided to Morokuma that President Quezon intended to designate Vice President Osmena to head the Philippine side of the Joint Philippine-American Preparatory Commission on Philippine Affairs and that Osmena would resign as Secretary of Education to fill the new post. ${ }^{189}$ Significantly, according to Aquino, when Osmena resigned, the then Secretary of the Interior Quirino would move over to the Department of Education, and Secretary Rodriguez would be appointed as Secretary of the Interior, leaving a vacancy in the Secretaryship of Agriculture and Commerce. Aquino believed that he himself was the leading candidate for the latter position. Moreover, Aquino said that he had consulted with both Osmena and Roxas who were supporting his candidacy. Upon receiving this news from Morokuma, Consul General Uchiyama reported to the Foreign Office that "in view of his attitude toward Japan," if the appointment of Aquino went through, "I think we will be in a much more advantageous position to settle the Davao problem than with Rodriguez. . . ."190 However, Uchiyama warned that with Rodriguez, as Secretary of the Interior, having direct responsibility for the Davao City Mayor, the Commissioner of Mindanao, and Sulu, "we can not permit ourselves any optimism." 191

Probably unfortunately for the Japanese this rumored shift in top government posts did not immediately occur. However, one appointment to a key position did seem favorable to Davao Consul Shibata Ichitaro. For in April, 1937, former provincial Governor of Davao Juan A. Sarenas was appointed Assistant Secretary of the Interior. Since Sarenas had for many years had a close relationship as a consulting attorney with the Furukawa enterprises and with a number of other Japanese firms, Shibata surmised that the appointment of Sarenas was being made chiefly in order to deal with the problems affecting the Japanese at Davao, problems with which Sarenas was well acquainted. 
Therefore, commented Shibata in a report to Consul General Uchiyama in Manila which was passed along to Tokyo, it was most important that Sarenas be "brought over" to the side of the Japanese and kept there. ${ }^{192}$

Among key figures in the legislative branch of the Commonwealth government, in addition to Sabido, in regard to matters concerning Davao the Japanese were perhaps closest to the Assemblyman from Davao, Romualdo Quimpo, who had also acted as an attorney for several Japanese firms. On the night of August 3, 1937, Quimpo held a long conversation with Vice Consul Kihara. ${ }^{193}$ Quimpo, who was about to leave for Hong Kong as a member of a legislative welcoming committee to meet President Quezon, who was en route home from Washington, discussed various aspects of the still pending Davao question. Assemblyman Quimpo said that, if he were asked about Davao, he intended to reply that any expulsion of the Japanese would lead to the destruction of the local economy and that therefore it would be to the benefit of both Japan and the Philippines to maintain the status quo. Moreover, Quimpo told Kihara that he would advise the President that the latter's efforts had greatly reduced the tensions over Davao and that to permit the matter to be raised before the Assembly for discussion and debate would only arouse dissension anew. Thus, Quimpo continued, he intended to urge Quezon to work for an understanding at the executive level between Japan and the Philippines, in particular the terms under which the original pakiaw contracts might be renewed. ${ }^{194}$

Also, according to what Quimpo relayed to Kihara, several members of the Assembly had asked his opinion of a possible purchase of the land held by the Japanese in Davao. Quimpo recounted that he had replied that, while such a purchase might hypothetically be possible and thus the Japanese would be expelled, the result would undoubtedly be the ruin of the abaca plantations and a very serious blow to the Philippine economy ${ }^{195}$ Nevertheless, such a proposal was made in November of 1937, by Assemblyman Augustin Kintanar of Cebu, who had been a member of the party which had accompanied the President on 
his journey to Davao in April, 1936. The Kintanar plan was to have the Philippine government buy up all Japanese holdings in Mindanao and resell them at cost in ten hectare lots to Filipino citizens. Assemblyman Kintanar said that he had long since recognized the tremendous cost of such a proposal and that that was why he had waited until the fall of 1937 to introduce his bill. However, said Kintanar, now that the insular treasury had in it some P100,000,000 derived from the refunded United States coconut oil excise tax, in addition to an anticipated annual income of some P50,000,000 from the same source and from other similar excise taxes, ${ }^{196}$ the government could well afford to set aside $\$ 40,000,000$ as a negotiating fund. The Assemblyman added that in his opinion the government ought to move quickly because the longer they waited the more the purchase was likely to cost.

Sadly this latest in the series of proposed monetary solutions of the Davao question met the same fate as its predecessors. Nor was it to be the last such, for in March, 1938, another bill introduced into the National Assembly again recommended tapping the coconut oil tax refund to purchase Japanese landholdings; but, as Mr. Kintanar had predicted, the ante was now raised, and the new proposal called for a P50,000,000 appropriation. Once more, however, the Japanese failed to evidence any interest in the sale of their holdings, and neither the government nor the Assembly pushed the issue any further. ${ }^{197}$

Meanwhile, the apparent continuing desire of both the American and Philippine governments to minimize the Davao problem was evident in an exchange of memoranda that took place in the fall of 1938, between the office of President Quezon and Brigadier Charles Burnett, Chief of the Bureau of Insular Affairs. ${ }^{198}$ Both documents were headed identically "The Davao Land Problem." In the memorandum from the office of the President to General Burnett, dated October 29, 1938, it was reported that, according to the Secretary of Agriculture and Commerce, Japanese landholdings in Davao then amounted to 63,765 hectares, of which 29,602 hectares were estimated to have been acquired legally under Public Land Acts 926, 2921, 
and 2975. The remaining 34,163 hectares were all lands being utilized by Japanese through either verbal or written agreements with Filipinos, and many of those agreements were clearly in violation of existing laws. However, it was stated that in the only four provinces where the Japanese were engaged in agriculture to any extent, Davao, Zamboanga (2,632 hectares), Cotabato (112 hectares), and Palawan (74 hectares), their holdings aggregated 66,584 hectares, which, out of a four province total area of 7,529,820 hectares, was "relatively insignificant."

In Davao Province there were said to be only about 14,000 Japanese, and there had been no signs of any unusual or rapid increase. The memorandum concluded:

Indeed the matter would not give much concern were it not for the fact that in Davao, the landholdings of the Japanese, said to be of the choicest lands in the province, enable them to control the business in practically all fields. It has been reported that goods sold in Davao are $90 \%$ Japanese, that the Filipino farm labor has been completely overshadowed. This is the situation that has caused alarm. ${ }^{199}$

The reverse memorandum from General Burnett to President Quezon was dated November $11,1938,{ }^{200}$ and was a summary of some of the impressions formed by the General after a recent personal visit to Davao. ${ }^{201} \mathrm{He}$ began with an account of a discussion he had had in Davao with certain leaders of the Japanese community: "Some apprehension was expressed by the Japanese Consul and Japanese businessmen over the possibility of the cancellation of Japanese leases by the Commonwealth Government. However, the Japanese Consul was confident that no action prejudicial to Japanese interests would be taken while President Quezon remained in office."

According to General Burnett, the Japanese Consul had also told him that the crux of the so-called problem at Davao was the pakiaw system, which the Consul said affected $70 \%$ of the land controlled by Japanese and which was probably legal. This left only about 8,000 hectares of Japanese-tilled lands which might be considered questionable, an amount which in the view of General Burnett was very small considering the vast expanse of Davao Province. There was, wrote the General, no difference 
whatever between the soil cultivated by the Japanese and the thousands of hectares of soil lying fallow, and therefore the development of the former was due entirely to the efforts of the Japanese over the previous thirty years. General Burnett concluded his memorandum as follows:

If a neutral but friendly observer might be permitted to offer a suggestion as to the settlement of this question, it would be to allow the status quo to continue until the expiration of these leases which the legal branch of the Government considers illegal, and then require a legal contract of the share cropper type to be made between the owner and the Japanese who works his land. The area of land involved is so insignificant that it would seem most unwise, for diplomatic as well as other reasons, to magnify the question into a "Problem." On the whole it would be rather easy to show that the existence of the present Japanese holdings as well as Japanese labor in Davao is a distinct asset and not a liability, to the Commonwealth Government. ${ }^{202}$

In late November of 1938, an important personnel change in the Commonwealth administration, one which the Japanese had heard rumors of for nearly two years, finally took place. Benigno S. Aquino replaced Eulogio Rodriguez as Secretary of Agriculture and Commerce. Shortly before the appointment was made by President Quezon, Acting Consul General Kihara told the Foreign Office that, "If [Rafael S.] Alunan is named Secretary of Agriculture and Commerce, it can be considered disadvantageous to us since he is the head of the pro-American faction and has a plan for the development of Mindanao. Aquino who has ties with us has been suggesting to Laurel and Sabido for the past several days that he be named to the post. According to Sabido, the President intends to name Alunan Secretary of the Interior and Aquino is almost certain to be named Secretary of Agriculture and Commerce in a few days."

Within a week both of the appointments reported in advance by Sabido were made, and the Japanese Acting Consul General was extremely pleased. Kihara wrote that Aquino was very different from Rodriguez and was much more understanding of the Japanese position at Davao. Of special pleasure to Kihara was the fact that he had direct access to Aquino, something that had never been easy with Rodriguez, and that Aquino was quick to take measures suggested by the consulate. ${ }^{204}$ There- 
fore, since it was thought by the Japanese that the appointment of Aquino represented a significant gesture to them by Quezon, the Davao question became correspondingly even less of an irritant to the generally smooth course of Japanese-Philippine relations.

As early as March 4, Acting Consul General Kihara was able to report to the Foreign Office that he had had a very satisfactory meeting with the new Secretary of Agriculture and Commerce Aquino. Aquino had agreed to permit Japanese 25-year leaseholders to renew all expiring leases, and he urged Kihara to tell them secretly that this would be done. According to Aquino, the expiring leases of Filipino leaseholders would be returned to the government, but the government would then arrange new leases directly with the Japanese farmers. Finally Aquino requested that Kihara keep the substance of his remarks completely in confidence but that he advise the Japanese in Davao to avoid scrupulously any untoward incidents which might in turn arouse public reaction to the extent that Aquino would be prevented from putting his plans into effect. ${ }^{205}$ Nevertheless, as United States-Japanese relations worsened, the Americans, who continued to bear the responsibility for Philippine defense, seemed to demonstrate a growing concern over the Japanese settlement at Davao. For example, in a lengthy memorandum submitted by General Burnett to the Secretary of War in January, 1939, on the subject "Japanese Penetration of the Philippine Islands," ${ }^{206}$ while terming his statements an "educated guess," and after again praising the Japanese undertaking at Davao as an outstanding example of Japanese thrift and enterprise, the General wrote that the Davao land problem posed a very perilous post-independence issue which might well pit a strong power against a weak power. The question then would be, as General Burnett viewed it, whether Japan would behave in the Philippines as she had in Manchuria and China, and the General's conclusion was that, if in the opinion of the Japanese leadership political domination became necessary for economic domination, it seemed to him most probable that the required steps would be taken to secure that end. 
Perhaps in line with such concerns, then Philippine Commonwealth Secretary of Finance Manuel Roxas was reported to be considering again a plan to close the port of Davao to foreign shipping. Ostensibly the proposal was, as the previous one had been, for the intended benefit of local shipping interests and would mean that all imports and exports at Davao would have to be transported to other ports. Practically speaking, however, since the Davao carrying trade was almost entirely in the hands of the Japanese, such a move would necessarily have an immediate detrimental effect on Japanese interests, whether to the advantage of Philippine shippers or not. Thus, Acting Consul General Kihara Jitaro voiced his strong opposition to the plan, describing it as generally retrogressive and as a certain hindrance not only to overseas Philippine commerce but to the possible industrial development of Mindanao. ${ }^{207}$

Once more, apparently in the face of such diplomatic pressures, no action was taken to close the port of Davao. In fact, certain leading public figures made efforts to allay any fears which the Philippine public might have about Japanese interests in Davao. For example, in an interview given prominence in the pro-administration Herald, Assemblyman Jose Romero was quoted as saying that the land holdings of the Japanese in Davao were "not alarming," since they were only some 60,000 hectares out of a total of about 1,000,000 hectares in the province. ${ }^{208}$ The Japanese, according to Romero, could continue to possess the lands which they then held, but they could not acquire additional land because of the provisions of the Commonwealth Constitution. He also said that he did not believe the government would go to the extent of seeking the expulsion of Japanese farmers from lands which a former Secretary of Agriculture and Commerce had alleged were acquired illegally. ${ }^{209}$

That the Japanese too were feeling far more secure about their holdings in Davao was evident in a report from Davao Consul Iwanaga Hiraku to the Foreign Office in April, 1939, after a visit to Davao by Secretaries Alunan (Interior) and Aquino (Agriculture and Commerce). Consul Iwanaga wrote 
that, after the two men had briefly inspected the Ohta and Furukawa plantations and the Japanese sponsored agricultural experiment station, they attended a dinner given by the Consul and demonstrated a very friendly attitude toward the Japanese. ${ }^{210}$ On April 2, Secretary Aquino attended a luncheon given by the newly elected Assemblyman from Davao, Cesar M. Sotto. Aquino, in his speech at that luncheon attended by 25 Filipinos, several Japanese including Consul Iwanaga, and two or three Americans, said that Filipinos as Asians must maintain and increase friendly relations with the various countries of the Far East. He also stated that Filipinos welcomed foreign capital and foreigners themselves into the Philippines but that Philippine laws must be strictly observed. Moreover, Aquino emphasized his opinion that for anyone to say that foreigners living in Davao were a threat to the Philippines was "some kind of fantasy." "11 Iwanaga was also encouraged by the confidential comment of Assemblyman Sotto that Secretary Alunan, who had in the past shown a certain prejudice against the Japanese in Davao, had said that on the basis of the present inspection trip he fully realized the contributions the Japanese were making to the development of products in the islands and would so inform the President. ${ }^{212}$

\section{The Alexander Resolution}

In May, 1939, the happy quiescence of the Davao problem over the preceding three years was rudely shattered. A bombshell of sorts was tossed into the lap of the Commonwealth government when Representative John G. Alexander, Republican of Minnesota, introduced into the United States House of Representatives a resolution demanding an investigation of Philippine-Japanese relations. The text of the Alexander resolution was as follows:

Whereas the people of the United States have a total investment in the Philippine Islands of $\$ 140,000,000$ of which $\$ 45,000,000$ is invested in Philippine Government Bonds guaranteed by the United States Government and $\$ 95,000,000$ is invested in commercial ventures; and $\$ 700$,000,000 by the Government of the United States; and

Whereas each year more and more Japanese people and businesses are moving into the Philippines; and 
Whereas certain Philippine public officials have leased large sections of land in Davao province to Japanese persons and companies; and

Whereas wives of certain Philippine public officials have leased shipping interests to Japanese persons and companies; and

Whereas certain members of the National Assembly of the Philippines and former members of the Philippine legislature have sold and leased lands and properties of Japanese persons and companies; and

Whereas many members of the National Assembly of the Philippine legislature have been accused of having been bribed by Japanese persons and companies; and

Whereas President Quezon and other certain Philippine public officials have attempted to inject a pro-Japanese attitude and spirit into the Philippine people in an attempt to disrupt the harmonious relations between the Philippines and the United States; and

Whereas a bill has been introduced and is now pending in the $\mathrm{Na}$ tional Assembly of the Philippines, the purpose of which is to amend the existing immigration laws of the Philippines so as to relax regulations regarding Japanese immigration to the Philippines;

Whereas President Quezon of the Philippines has repeatedly appointed to high public office Japanese-minded persons; and

Whereas certain sources and amounts of President Quezon's income are allegedly unknown and unaccounted for; and

Whereas under the administration of President Quezon the freedom of speech and press has been impaired and the use of the mails denied persons in transmitting unfavorable information regarding the policies of President Quezon; and

Whereas the legal rights of the United States government and of the citizens of the United States and of the Philippines have been invaded by the Government and officials of the Philippines; Now, therefore, be it

Resolved by the House of Representatives that for the purpose of obtaining information necessary as a basis for legislation, the Speaker shall appoint a special committee of six members with power to issue subpoenas, to investigate the aforesaid matters and to ascertain the advisability of more definitely determining our immediate and our future relations with the Islands. The chairman of the committee or any member thereof may administer oaths to witnesses. Every person who, having been summoned as a witness by authority of said committee or any subcommittee thereof, willfully makes default, or who having appeared refuses to answer any questions pertinent to the matter herein authorized, shall be held to the penalties provided by section 102 of the Revised Statutes of the United States, as amended (U.S.C. 1934 edition, title 2, sec. 102).

And be it further resolved that said committee be allowed $\$ 100,000$ to carry on said investigation.

The committee shall report to the House as soon as practicable the results of its investigation, together with such recommendations for remedial measures or for legislation as it deems desirable. ${ }^{213}$

Clearly the resolution had no chance of passage whatever but had been introduced by Congressman Alexander in order to attract attention to a situation on which he wished to focus public 
concern. Nevertheless, an outburst of indignation characterized the violent reaction of President Quezon and his administration.

Immediately two points seem to be worthy of some investigation: namely, why did Congressman Alexander make these charges, and was there any validity to them? Mr. Alexander himself in answering the first question states:

My interest in Philippine affairs was the result of 20 years of study, beginning at the close of World War I, of the probability of another World War, and the factors leading to the outbreak of same. It was my theory, based on the need for Japanese industrial expansion and their action in Manchuria and China, and their penetration of the East Indies and the Philippines, that they were about ready to make an attempt to grab the entire area. This was made especially apparent from the fact that there was a considerable movement in this country to pull our military forces out of the Orient. ${ }^{214}$

The Quezon administration obviously had a very different interpretation of Rep. Alexander's motives. They made their views known through the pro-administration Herald in an editorial entitled "Are We Pro-Japanese."

Minnesota, which is the Congressman's own state, is part of the dairy bloc. The dairy bloc is part of the group opposed to the Philippine bill now pending in Congress. This opposition is based on the belief that Philippine coconut oil, some of which is converted into butter and fat substitutes, is harmful to the American dairy industry. Opponents of the bill can attack it either frontally or insidiously. A frontal attack is successful only with facts for ammunition. When there are no very valid arguments in one's arsenal, the underhanded, illicit attack is the only tenable method. ${ }^{215}$

Indeed the Joint Preparatory Commission on Philippine Affairs had submitted its reports, and the American Congress had before it an administration-sponsored bill proposing amendments to the Tydings-McDuffie Act. This proposal sought to substitute declining duty-free quotas for gradually increasing export taxes on Philippine shipments to the United States, a proposal which was calculated to reduce gradually the import volume of such commodities as coconut oil but which would continue to permit a profit to be made on the remaining trade. Naturally this was a bill strongly favored by President Quezon and his government; and thus it was believed in the Philippines, 
whether rightly or wrongly, that charges such as those leveled by Representative Alexander were indirectly aimed at preventing its passage.

If indeed the efforts of Mr. Alexander were a supposed smokescreen to shroud his real purpose of aiding Minnesota dairy interests, one can only feel the deepest sympathy for the Congressman, since the amendments to the Tydings-McDuffie Act passed Congress with ease and were signed into law by President Roosevelt on Aug. 7, 1939. Moreover, Representative Alexander was himself defeated for reelection in 1940. In his own words, Mr. Alexander says:

The outcome of the efforts which I made were not too encouraging. The people of my own area in this State felt that this was an activity to which their member of Congress did not need to give attention. However, immediately after the attack on Pearl Harbor many people came to me to admit their error and say that they could see now that they had been mistaken in criticizing my activities, but of course, by then it was too late. ${ }^{216}$

Yet another explanation of the Alexander Resolution was contained in a dispatch dated May 22, 1939, from Acting Consul General Kihara in Manila to Japanese Foreign Minister Arita Hachiro. The real culprits, according to Kihara, were the Communists. It was the Communists, he suggested, who had probably instigated the Alexander Resolution in order to strengthen the opposition in the United States to Philippine independence and to encourage the bolstering of American military forces in the Far East and thus to "counteract the Japanese policy of the Quezon government." ${ }^{217}$ Kihara maintained that ever since July, 1937, the Communists had been leading the anti-Japanese movement in the Philippines, ${ }^{218}$ that they had been propagandizing about Japanese aggression, and that they had consistently criticized and attacked all plans for Philippine-Japanese friendship and cooperation. He further contrasted most unfavorably the Communists' purported position with the strict neutrality to which the Commonwealth government had thus far adhered. Therefore, Consul Kihara saw the Alexander Resolution as a logical culmination of the efforts of "Communists" to turn the Philippines against Japan. ${ }^{219}$ 
The second point raised earlier was to what extent the bill of particulars contained in the Alexander Resolution was valid. Again, it seems appropriate to quote the editorial reply of the Herald:

... There are only three facts that may give credence to the charge that we are pro-Japanese. First of these is the known desire of President Quezon to establish friendly relations with our neighbors including Japan. We shall have to live with the Japanese and other neighbors in this part of the world. Prudence dictates that we befriend them. If this is pro-Japanese then let us make the most of it.

The other facts are the growing Japanese dominance of the retail trade, and the unfortunate Japanese control of the economic life of Davao. But if this is pro-Japanism, then the American government is more at fault than the Philippine Commonwealth. The entry of Japanese goods and immigrants had its highest peak during the Jones law regime. Most of the Davao landholdings of the Japanese were acquired under the noses of American Governors General.

With respect to the possibility that some Filipino citizens, including officials or their wives, have been acting as dummies for Japanese investors or corporations, it will suffice to mention that the Department of Justice has for some time been investigating reports with a view to prosecuting those that might have violated the strict laws regulating the participation of aliens in Philippine natural resources. We do not need a congressional investigation to remind us to enforce our laws.

The Commonwealth Government is doing what it can to liquidate the unfortunate situation inherited from the American Governors General. But even in this task, it is somewhat handicapped. To America, Japan comes under the label of foreign affairs, and the State Department has repeatedly shown lack of sympathy for most of the attempts in Manila to inquire into Japanese landholdings, understandably because any new irritation in American-Japanese relations can always have repercussions. The only weapons available to the Philippines, furthermore, are the tariff and immigration laws, and the Philippines is not in full possession of them. Legislation on these subjects have still to be approved in Washington. ${ }^{220}$

Certainly the most persuasive argument made in the preceding editorial was that the American colonial administration and subsequently the State Department under the Commonwealth regime had consistently followed a policy of extreme caution with regard to Japanese interests in the Philippines. The failure of the United States government to take a stronger stand in behalf of the actions proposed by Secretary Rodriguez, for example, had at least in part contributed to the reluctance of the Commonwealth administration to act more forcefully on its own in Davao. It was also true, of course, that the original 
influx of Japanese immigrants into the Islands had been officially encouraged by the American authorities in order to provide labor for the Baguio road project and later for American-owned plantations in the Davao region. Another telling point in the Quezon government's defense against the Alexander charges was the statement that with independence only a very few years away, "prudence" dictated that the Philippines exert its efforts to establish friendly relations with the Japanese. The harsh realities of international life certainly had made it highly inadvisable for a weak Philippines about to embark on a perilous and lonely voyage to antagonize a powerful Japan.

Perhaps the least impressive contention of the Herald editorial was the bland assertion that the Department of Justice was "investigating reports" that Filipino citizens, including government officials or their wives, might have been acting as dummies. Information on this particular phase of Japanese operations in the Philippines had been available for years, and the close ties between influential Filipinos and Japanese businessmen were widely known. In fact, it was this particular aspect of Representative Alexander's accusations that received the most support in the Islands, although the bulk of that support came from Filipino liberals or radicals of diverse political colorations, who were perhaps less concerned with the danger of Japanese penetration than they were with stirring up opposition to the Quezon administration and its caciquist supporters.

For example, Congressman Alexander had reprinted in the Congressional Record a letter to him signed by Luis Agudo, Secretary of the Pagkakaisa ng Bayan, or Popular Front, in which Agudo praised the Congressman for his proposed investigation and said that Japanese infiltration had reached a "serious proportion" with a number of public officials involved in the selling or leasing of lands to the Japanese. ${ }^{221}$ Similarly Vicente Sotto in his anti-Quezon publication Union wrote an article entitled "Congressman Alexander's Charges Are not Groundless," in which he termed the legislator's conclusions "exaggerated," but nevertheless suggested that there was sufficient basis for his charges. Sotto referred to the list of government officials impli- 
cated in the earlier Rodriguez investigation, the denunciation by then Governor Garcia of Bohol of public officials including members of the National Assembly who were acting as dummies for Japanese lumber concessionaires, and the Filipino men and women who lent their names to Japanese fishing boats, mineral concessions, or pasture land leases. ${ }^{222}$

At any rate, the opening salvos had been fired, and the verbal battle between Representative Alexander in Washington and the Quezon administration in Manila was on. On May 23, on the floor of Congress, Alexander charged that President Quezon was attempting to establish a dictatorship in the islands, an accusation that incidentally was by no means new and had been made repeatedly by opponents of Quezon in the Philippines as well. Alexander also claimed that Quezon was trying to have the Constitution amended so as to able to succeed himself, a development which, despite the most vociferous denials at the time, was to become a reality in amendments to the Philippine Constitution approved by President Roosevelt on December 2, 1940, and under which President Quezon was indeed reelected in 1941. Morover, Congressman Alexander broadened his attack to include Vice President Sergio Osmena for having made several trips to Japan and for having been "instrumental in the sale of land to Japanese." ${ }^{223}$ Coincidentally Osmena happened to be in Washington as head of the Philippine mission, working for the passage of the amendments to the Tydings-McDuffie Act.

Meanwhile, in the Philippines the Quezon administration was defended by Governor Pacifico Sobrecarey of Davao, who said he had made a study of the so-called Davao problem and had found that no Filipino official was involved in any Japanese land lease as alleged by Representative Alexander. If anyone were at fault in leases to Japanese of public lands, said Sobrecarey, it was clearly the Americans, since the leases under fire were all negotiated in the era of the American Governors General. Sobrecarey noted that neither the former legislature nor the present National Assembly under the Commonwealth had amended the public land laws to permit the Japanese to purchase or to lease public lands. According to the Davao Governor 
the whole issue was ridiculous anyway since the total area leased to the Japanese covered only 19,976 hectares. ${ }^{24}$

On June 12, Representative Alexander resumed his offensive with an allegation that Japan had gained control of a number of important island industries such as lumber, fishing, and hemp through an "economic invasion" of the Philippines which President Quezon had done nothing to check. Said Alexander, "Surprising is the attitude of the dictatorial president . . . that even at the height of his popularity he is described by some of his countrymen as having cold feet . . . . To all intents and purposes, Davao is as much Japanese territory as Manchukuo." The Japanese, charged Alexander, had illegally gained control of 170,000 acres of agricultural land and many more acres of timber land. He said, "In Davao the Japanese are practically running an independent state," and he blamed "crooked governmental officials, lawyers and ignorant natives." He added:

Filipino authorities are afraid to do anything about the steady flow of short, wiry, hardy astute yellow men into what has proudly been called in the Philippine Commonwealth constitution "the patrimony of the nation." They are resigned to the coming of the Japanese. They admit frankly that they can not afford to make an unfriendly gesture toward their invading neighbors. "Tomorrow they may be our masters" they say in a matter-of-fact way. ${ }^{225}$

The major effort of President Quezon to reply in detail and to try to refute the accusations of Representative Alexander came in a speech to the people of Davao on June 28, 1939, on the occasion of a trip by Quezon to lay the cornerstone of a barrio obrero at Piapi, Davao. His words are here reproduced verbatim:

Now,-lastly Davao has been prominently mentioned in the newspapers for the last number of years. It has been prominent in the newspapers of Manila and much more prominent in the newspapers of America. Recently, a member of the Congress of the United States who, by the way, is not one of the prominent leaders of Congress, has been speaking a lot about the situation in Davao. He has accused me of protecting the Japanese and tolerating their illegal transactions here. You the people of Davao know that when I became President of the Philippines, the lands that are now occupied by the Japanese, the land that they claim to be theirs, was already in their possession. The residents of Davao know that the question of the Japanese Colony in Davao took place under the American administration; that the man who brought Ohta to 
Davao was Carpenter; that it was Governor Forbes who sympathized with the policy of developing Mindanao even with the help of foreigners. The situation created in Davao has been created not only under the American flag but by American administrators. It is not only unfair, it is worse than that, for an American representative in Congress to be accusing now the Filipino officials for something his countrymen have done before. I am not criticizing what ex-Governor Carpenter and what exGovernor Forbes have done. I am not condemning them, but if it were true what Congressman Alexander says that because of the development of Davao by the Japanese the Philippines has been turned over to Japan, then it is the fault of ex-Governor Carpenter, ex-Governor Forbes and other American officials that Davao has been turned over to Japan, and not any Filipino official.

Now, my countrymen, I am not going to pay more attention to that nonsensical and absurd speech of Congressman Alexander. I am going to tell you that we are facing a practical question in Davao. Many of these plantations are admittedly legal. Some of these plantations, it is alleged, have not been acquired legally by them. If it were true that some of these plantations have been acquired illegally by the Japanese, it is the fault of the Filipinos in Davao who allowed themselves to be used by the Japanese. And, moreover, if it was true that some of these plantations are illegally in the hands of the Japanese, it will be almost impossible for the government to prove that it is illegally in the hands of the Japanese because the Filipinos who have allowed themselves to be used by the Japanese will testify in favor of the transaction and make it legal when tried before the court. What would have been the result if I had ordered proceedings in these cases? It would have created a lot of trouble; it would have arisen antagonism on the part of the Japanese; and perhaps we would have lost the cases in the courts.

This is a purely practical question of administration. After all, how many thousands of hectares are in the hands of the Japanese legally or illegally? Nobody claims that they have more than twenty-five thousand hectares. How many thousands of hectares do you think you have in Davao? You have over one million hectares there. Well, my goodness, unless a man is crazy, he cannot say that the Japanese own Davao because they have forty-five thousand hectares when we have over a million hectares here that can be the land of the Philippines. Now, no government can save a country when the people of that country do not want to be saved. It makes no difference whether under our Constitution the right to own public land is limited to Filipino citizens. As long as there are Filipinos who are willing to sell their rights, the Constitution cannot do anything. The possession by the Japanese of these forty-five thousand has done you no harm so far. They have developed these lands that were undeveloped before. They have taught us how to have a modern plantation of abaca. They have brought here that ramie and I am planting ramie now in my hacienda in Arayat because we have learned from the Japanese here in Davao. If the Filipinos should take advantage of what we can learn from what the Japanese is doing here, the coming of the Japanese to Davao, instead of being an evil, it would be a blessing for the Filipino. The Japanese are complying with the duties of a foreigner residing in a foreign country. So far, so far, I say it again, the Japanese 
have not done harm to the Philippines. It is our duty to treat them fairly and we have the right to expect from them obedience for our laws. If the Filipinos in Davao or in other parts of the country should prove themselves Filipinos and will not sell their rights, we have the Constitution that protects the permanent interests of the country and we have a government that is sworn to carry out the provisions of that Constitution. The Philippines' future is safe, but if the Filipinos have more love for money than for their country, nobody can save the Philippines-let us all go to hell. (Laughter and applause) ${ }^{226}$

The very next day the Herald, after praising the brilliant address of the President at Davao, took up the cudgels editorially and set out after Representative Alexander again:

Congressman Alexander has accused the Philippine administration of pro-Japanism largely on the basis of the Davao Japanese problem. To say the least, this is hardly fair. Not only has the problem been inherited but its solution may not be entirely in the hands of the Commonwealth. The foreign affairs of the Philippines are still under the supervision of the Washington State Department, and Tokyo may have to have a hand in the proper solution of the Davao Japanese problem. Congressman Alexander might try to ascertain whether or not he has been barking at the wrong tree.

There still remains the question of whether or not there is a Japanese problem to solve. Some observers are of the opinion that there is such a serious problem, others are convinced that there is none. Certainly the excessive acquisition of property and control of communities, commerce, and the means of transportation and communication by foreign nationals may constitute a problem. On the other hand, every nation harbors foreign communities apparently without suffering any serious consequences. The Alexanders, before jumping at conclusions, might first do a little limbering up by way of getting the pertinent facts. ${ }^{227}$

The overwhelming passage by the United States Congress of the amendments to the Tydings-McDuffie Act seemed to bring an end to the efforts of Representative Alexander to ferret out Japanese "subversion" in the Philippines. Apparently President Quezon too felt that his most recent Davao journey and his remarks on that occasion had once more becalmed a potentially turbulent situation. For in an interview with a Japanese journalist, the text of which was published in 1940, the Philippine President could say, "The Davao problem gave us a great deal of concern at the time, but fortunately at present the whole question has disappeared not leaving even a trace of the trouble. No one takes up the subject again." ${ }^{228}$ 


\section{Danger Ahead: Provincial Politics}

However, a storm in the teacup of Davao provincial politics in 1939 threatened to undo all of the earnest behind-the-scenes efforts of both Quezon and the Japanese consular authorities to minimize the controversial aspects of the Japanese settlement at Davao. While the Japanese were probably not overly surprised at these developments since they had had thorough exposure to Philippine politics both at the national and local levels, as the Foreign Office archives reveal, they were more than ordinarily concerned. And the roots of their concern stemmed both from the realities of the depth of their involvement in Davao provincial politics as well as from their immediate desire to keep the Davao issue out of the limelight of national attention. Moreover, since once again as in the Pelayo situation a few years earlier, a bitter feud between Filipino personalities and factions was the source of the difficulty, the Japanese had legitimate cause to be disturbed.

In the general election of 1938, there had been a very hard fought and extremely close three-way race for the post of Assemblyman from the province of Davao. Cesar M. Sotto had won the election by a very slim margin over both the incumbent and official administration candidate Romualdo C. Quimpo, and former Governor Juan E. Sarenas, who finished third. ${ }^{229}$ After his defeat Quimpo was appointed as a technical assistant to the President detailed to the Department of the Interior, where he assumed the role of private secretary to the Secretary of the Interior himself. Since the election had been so bitterly contested and since the personal rivalry between Sotto and Quimpo was so profound, each man seemed determined to utilize his new position to secure revenge against the other.

After his victory Sotto had affiliated himself with the governing Nacionalista Party and was so designated on the rolls of the Assembly. However, Quimpo, apparently still smarting from the effects of his loss, seemed determined to utilize his new appointment to block every action which Assemblyman Sotto intended to take on behalf of his constituents in Davao. Faced with this most distasteful dilemma Sotto resorted to one of the older 
but more reliable tricks in the bag of the Davao politician, namely, the filing of a bill of administrative charges against Quimpo, alleging anomalies during his previous incumbency, including "corruption by foreigners," and specifying that Quimpo had taken money from the Japanese Association of Davao.

As soon as this controversy became known, Acting Consul General Kihara and Davao Consul Iwanaga were of course extremely eager to bring it to a conclusion as rapidly as possible. Logically they preferred not to have the role of the Japanese in Davao politics placed under close public scrutiny. Even more disturbing, however, was the possibility that any prolonged dispute between the two Filipino politicians might rake up all of the quietly smoldering coals of the Davao land question again.

Kihara reported to the Foreign Office that he had tried various means of mediating the dispute and had consulted Morokuma, who had in turn approached Assemblyman Sotto both directly and indirectly without success. ${ }^{230}$ Moreover, since Kihara viewed the whole affair as "very dangerous" vis-a-vis Japanese interests and felt that whatever proposals for mediation were made by himself might become political footballs in the next election, he thought it would be far safer for some Filipino personality such as the Davao attorney and politician Rafael Castillo to act as mediator. ${ }^{231}$ Kihara also advised Davao Consul Iwanaga that, if mediation should not be possible and an investigation of the charges should in fact be made, Quimpo and his faction did not want the account books of the Japanese Association to be made public for fear of exposing Laurel and Sabido. Therefore, the Acting Consul General suggested that the Association might state that the records of payments made through 1938 were entirely unclear since the man who made such payments, Murakami, was now deceased..$^{232}$

On September 24, 1939, Kihara managed to arrange a meeting between himself and Assemblyman Sotto. Kihara told Sotto that although he did not want to get into the dispute between the two men, Quimpo in truth never had had any relations with the Japanese Association, and, if Sotto persisted in his present 
course, he would only stir up the Davao land problem contrary to the wishes of President Quezon and possibly create a crisis in Japanese-Philippine affairs. ${ }^{233}$ Sotto replied confidentially to Kihara that while the heart of his charges against Quimpo was the latter's corrupt practices, since proof was very hard to obtain and he did not want to revive the land question, he "would not emphasize this too much."234

Of course, what the Japanese found themselves involved in once more was a local Philippine political vendetta in which they, as the principal economic factor in the province, were both the logical target of political attack and the principal potential source of political largesse. Thus, while Davao politicos were not above venting their spleen on each other via mutual accusations of being in the pay of the Japanese, none of these men really wanted to do any more than snap at the hand that fed them since all of them, in effect, ate out of the same hand. After all, Sotto himself intended to run for reelection and obviously did not intend to alienate the Davao Japanese though perhaps he did intend to frighten them sufficiently so that he could count on their financial assistance in the next campaign.

At any rate, the brief flurry which had already shown signs of petering out at the time of the Sotto-Kihara conversation dissipated still further when a month later it was reported that Sotto was withdrawing his charge of "corruption by foreigners" from the bill of particulars against Quimpo. ${ }^{235}$ Ultimately, following a special investigation of Quimpo's affairs by ex-Governor Exequiel Santos of Nueva Ecija, President Quezon issued an executive order exonerating Quimpo from Sotto's charges saying that the accusations against Quimpo had not been proved...236 Thus, through the combined efforts of the Japanese consular staff and the Commonwealth executive plus the canny political sensitivities of the politicians of Davao yet another potential stimulus to the revival of tensions over the Davao land problem was laid to rest.

\section{A Solution Achieved}

During 1940, while Japanese-American relations worsened, both Japanese and Filipinos continued to exercise care and dis- 
cretion in dealing with Davao. In July of 1940, for example, it was announced that former Japanese Foreign Minister and future Ambassador to the United States Nomura Kichisaburo was to make a visit to the Philippines to "inquire after the health" of the Japanese community in Davao. ${ }^{237}$ When Nomura actually reached the Philippines and visited Davao, he laughed uproariously when he was told of the supposed reason for his trip and said he had no special interest in "health." 238 Nomura referred to his visit as purely a personal and private one. He said he had no comment on the new immigration legislation which had just been enacted by the Philippine Assembly other than to express a hope that legitimate Japanese enterprises would in no way be hindered. Moreover, Nomura stated that the so-called Asiatic Monroe Doctrine set forth by former Foreign Minister Arita was based solely on "good neighborliness" but that Japan had no intention of interfering in Philippine affairs. ${ }^{239}$ Overall Nomura's appearance at Davao was well received in the Philippines largely as a result of the low key of his travel plans and of his remarks in the Islands.

That similar efforts from the Philippine side were being made to keep the Davao situation on as even a keel as possible was evident the following month when President Quezon too traveled to Davao. The purpose of the President's trip was to meet High Commissioner Francis B. Sayre, who was to be present at the opening on September 3, of a new national road from Davao through Bukidnon to Cagayan. On the morning of the 29th of August, the day of his departure, Quezon met with Consul General Yoshida Tanichiro, whom he told:

For the High Commissioner and myself to head for Davao at the same time should be avoided in these times, but, since the circumstances are unavoidable, I will arrive at night, spend the night on board ship, land early next morning and without stopping a moment in Davao will head by automobile directly for Bukidnon. I do not want any special importance to be attached to the occasion nor do I want the Japanese to endure any needless anxiety. ${ }^{240}$

For the President to go to such extremes to reassure the Japanese Consul General verbally and the Japanese community in Davao by scrupulously staying out of the city was certainly a diplomatic 
gesture of the highest order, which could only serve further to reinforce the image of Quezon's profound desire for correct and friendly relations with Japan.

In February, 1941, Kihara Jitaro, who had previously served in the Philippines as both Vice Consul and Acting Consul General in Manila, was, after an absence of only a year, appointed Consul at Davao. On his arrival back in the Islands Kihara was asked by the Philippine press about the world situation. He said he saw no cause for alarm since Japan had no desire for war with the United States, and he explained somewhat poetically that the reason for the return from Davao to Japan of so many Japanese and their families was not for "evacuation" purposes as some rashly suggested but rather "to see the cherry blossoms in spring." ${ }^{241}$ However, as the number of Japanese booking return passage to the homeland continued to increase, anxious Filipino reporters continued to direct their inquiries to the Japanese Consulate in Davao. Consul Kihara's secretary now informed the questioners that the women and children were leaving in order to be in Japan in time for the opening of school, explaining that some schools opened in April, some in May, and some in June. He positively denied that there had been any official evacuation order from Tokyo. ${ }^{242}$

Undoubtedly one consideration in the appointment of Kihara as Davao Consul was his long-standing close personal relationship with President Quezon. Evidence of the significance of this factor was contained in a dispatch to the Japanese Foreign Office dated April 6, 1941, which reported that the President had confided to Kihara that it would pose a serious problem for future Japanese-Philippine relations if Quezon were to leave office with the Davao land question still unresolved. Since, according to Quezon, he himself was the only person in the Philippines with sufficient influence to persuade the public to accept a solution that would be mutually agreeable to both Japan and the Philippines, he recommended immediate consultations to this end be undertaken between Kihara and Secretary of Agriculture and Commerce Aquino. ${ }^{243}$ During the next few months these talks continued with President Quezon having made it 
clear that what disturbed him most in the present situation was the role of the Filipino and American leaseholders who were subleasing to the Japanese. In mid-September the role of principal Philippine negotiator was assumed by Secretary of the Interior Rafael Alunan, who informed Kihara that if the Japanese themselves would rigidly control any further illegal cultivation at Davao, the Commonwealth government was prepared to accept the status quo until 1946, when an independent Philippines could enter into direct negotiations with Japan. ${ }^{244}$

The Japanese consulate then proceeded to draw up a document which embodied the terms of such an agreement and showed the memorandum to Alunan without requesting any signatures. The Japanese Consul General advised the Foreign Office that insistence on signatures would only have complicated the procedure, especially since the Philippines was not yet an independent state, and formal agreements with the Commonwealth government were obviously internationally unenforceable. However, Consul General Niiro Katsumi stated in his report that he felt confidence in the Filipino leadership since both Quezon and Osmena approved of the present settlement. ${ }^{245}$

It is perhaps most interesting to note that this agreement was reached within the framework of the close personal ties between President Quezon and the leaders of the Japanese community and members of the Japanese consular staff in the Philippines, ties which continued unimpeded by the worsening relations between the United States and Japan. ${ }^{246}$ Unfortunately, however, the ultimate tragic denouement was foretold in a dispatch from Foreign Minister Togo in Tokyo to the Japanese Consulate in Manila dated Dec. 2, 1941:

For our convenience we shall have Kihara remain in Tokyo for the time being, so please inform Quezon through Vargas that Kihara caught a cold as soon as he arrived in Tokyo and is resting and will not be able to return to his post as scheduled.247

\section{Conclusion}

By the outbreak of World War II, the key role of the Japanese in the economic and even the political life of Davao Province was clear. The extent of Japanese landholdings need 
not be repeated here, nor is it necessary to reiterate the Japanese domination of trade, commerce, and industry in Davao. It was unquestionably Japanese capital and Japanese labor that had made Davao one of the richest provinces in the Philippines, and these developments had undoubtedly provided a signal contribution to the economic growth of the new nation. What is probably less desirable in the overall evaluation of the Japanese settlement in Davao was the practical creation of a kind of state within a state and the cooperation of a significant number of educated, articulate, and influential Filipinos in that phenomenon.

"Davaokuo" was surely an exaggeration, but there is sufficient truth in the symbolism of the term to cause one to wonder why the communal exclusiveness of the Japanese in Davao had persistently prevented the emergence of any semblance of integration into the Filipino nation. On the eve of Pearl Harbor one of the most perceptive observers of Philippine life, Teodoro Locsin, thought he had the answer:

In the United States, the first generation of Japanese immigrants have clung to their old customs and traditions, and doubtless continue to look upon Japan as a home. The second generation, torn between loyalty, not to Japan, but to their parents, and loyalty to the country of their birth, may however be counted upon to align themselves, in a crisis, with America. Japan holds nothing for them, America holds everything. The third generation Japanese, with no experience of divided loyalties, are Americans through and through. Their children will be even more so.

To the Japanese immigrant in America, his new country offers freedom of opportunity, freedom of intellect, freedom of choice and freedom of growth. America makes him free. A man's home is his castle, not the Emperor's preserve. The woman strikes off the ancient chain that binds her to the man in feudal subservience. She becomes the equal of man. For the first time, she is a person.

Filipinos are, today, second-generation Americans. They are still torn between respect for the old and admiration for the new. They have nothing settled and definite to offer the Japanese in this country as an irresistible exchange for old and tried Japanese ways. In many ways we are as "conservative" as the Japanese. One does not trade one set of prohibitions for simply another set. 248

However, the isolation of alien communities in foreign environments was by no means an uniquely Philippine experience. Nor was the economic dominance attained by the Japanese in 
Davao unknown in other societies, e.g., the Chinese in Malaya or the Indians in East Africa. What seemed particularly unfortunate in the Philippines was the extensive cooperation in advancing their interests which the Japanese obtained from a number of high ranking and influential Filipinos. And in this context by cooperation literal and substantial assistance to the Japanese in securing their economic control of Davao is meant, and the roles of men like Laurel and Sabido in this regard have already been detailed. ${ }^{249}$ In essence, however, this meant political control as well, since many of the provincial officials of Davao were to varying degrees financially involved with and therefore subservient to the Japanese; and several national figures, especially the provincial representatives at Manila, were similarly indebted to the Japanese.

It seems fruitless to make long lists of those implicated in such arrangements, but many of them had actually migrated from Luzon or the Visayas to seek their fortunes with the Japanese in Davao. Let one prominent example, former Davao Governor Juan Sarenas, originally from Nueva Ecija, suffice. Sarenas had moved to Davao where he drove about the province in a large Studebaker automobile, reportedly a gift from Ogawa Yosaburo of the Southern Cross Plantation Company. It was also Attorney Sarenas who chastised his countrymen for calling Davao "Davaokuo" and who publicly acclaimed the contributions of the Japanese:

That this people control the hemp industry in Davao is but natural because more than anybody they are engaged in the hemp industry. In like manner we control cockpits and other holiday places of diversion, because more than anybody else we indulge in them. So-should we blame these people for controlling the hemp industry. ${ }^{250}$

Sarenas, as noted earlier, was also on the payroll of the Furukawa Plantation Company as their consulting lawyer and served several other Davao Japanese firms in the same capacity. His special role for the Southern Cross Plantation Company was typical of that filled by his countrymen for many other Japanese enterprises. The following letter ${ }^{251}$ speaks for itself: 
Southern Cross Plantation Co., Inc.

Planters \& Hemp Exporters, Davao, Davao, P.I.

August 11, 1941

The Honorable Commissioner

Securities and Exchange Commission

Manila

Sir:

Replying to your communication of July 10, 1941, I have the honor to submit the following for the purpose of record:

PRESENT STOCKHOLDERS:

J. A. SARENAS

560 shares

C. MURAKAMI

190 shares

Y. OGAWA

190 shares

E. M. SARENAS 252

50 shares

HIDEKO OGAWA

10 shares

1000 shares

PRESENT MEMBERS OF THE BOARD OF DIRECTORS:

J. A. SARENAS

President

Y. OGAWA

Vice President-Treasurer

C. B. SARENAS 253

E. M. SARENAS

Secretary

HIDEKO OGAWA

Director

C. MURAKAMI

Director

Director

(NOTE: C. Murakami died some time in 1938 and his properties are under administration, the administrator appointed by the Court being Y. Ogawa.)

Respectfully yours, (Sgd.) J. A. Sarenas

President

In the general election of 1941, Davao Assemblyman Cesar Sotto (originally from Cebu) ran for reelection. Having affiliated himself with the Nacionalista Party after his election in 1938, he expected to be the official candidate. However, his bitter dispute with former Assemblyman Romualdo Quimpo caused Sotto to be abandoned by the Nacionalistas when, for the 1941 campaign, Davao was declared a "free zone." And his opponent who had the full support of Quimpo and the implicit support of Quezon was none other than Juan A. Sarenas, who had finished third in the 1938 election. Both Sotto, supported by the mayor of Davao, and Sarenas, supported by the Davao provincial governor, sought Japanese campaign assistance. To 
this end Davao Consul Kihara requested from the Foreign Office 5,000 pesos to be used to "support and guide" both candidates and also to provide a fund to deal "in an appropriate manner" with the successful candidate. ${ }^{254}$

During the campaign itself the influence and prestige of Quimpo in behalf of Sarenas began to tell, and Sotto in desperation resorted to attacks on Sarenas for his "secret ties" with Japanese companies. ${ }^{255}$ At one point Sotto had prepared cartoons unfavorable to Japan for distribution as campaign literature to be used against Sarenas. However, Consul Kihara feared that such propaganda might rekindle the whole land question which had just been so satisfactorily settled in Manila. Therefore, he requested Sotto not to use such materials for the reason indicated, and Sotto complied ${ }^{256}$-a rather amazing example of the extent of the influence which the Japanese were able to wield in Davao politics.

That the Japanese used tactics such as these is perhaps regrettable though surely understandable. What seems more regrettable is that such machinations should have proved as successful as they did. The hard core of the Japanese population at Davao probably never exceeded a maximum of about 18,000, so that numerically, despite their alienation from the mainstream of Philippine life, they posed no particular threat to the Islands. Japanese landholding in Davao, though again small in terms of acreage, was indeed highly productive and an undeniable economic asset. However, neither cultural isolation nor economic wealth need have resulted in provincial political control which in turn affected national politics at the highest levels. For this latter development the Filipinos had only themselves to blame.

In sum, the Davao problem as it affected Japanese-Philippine relations serves to epitomize three distinct aspects of those relations. First, despite almost continuous criticism in the Islands and especially in the United States, the success of the Japanese in maintaining and indeed improving their position at Davao unimpeded is certainly strong evidence of the excellence of Japanese diplomacy in general and of the astuteness of Japanese 
representatives in the Philippines in particular. The latter factor is demonstrated not only by the high level of mutual confidence that was attained between President Quezon and the Japanese consular corps but by the actual complicity with the aims of Japanese policy by important personalities like Laurel and Sabido. Secondly, the handling of the Davao question provides ample support for the thesis that the American government was determined to take no action in the Philippines which might be misconstrued by the Japanese as unfriendly and certainly did nothing, especially during the Commonwealth period, which might have encouraged the Filipino leadership to take a firmer stand toward the Japanese. Thirdly, the successful resolution of this difficult problem between Japanese and Filipino officials, in an era of constantly worsening American-Japanese relations, is a tribute to the remarkable statesmanship of President Quezon, whose principal concern throughout continued to be to try to insure for the soon-to-be-independent Philippines as safe a course as possible through the stormy seas of international relations. 


\section{Footnotes}

1. Davao became a regularly organized province and elected its own provincial board for the first time in 1922, and the city of Davao was created by the Philippine National Assembly on October 16, 1936.

2. There have been many and extensive studies of the Japanese in Davao. The most recent scholarly research has appeared in two articles by Prof. Cecil Cody: "The Consolidation of the Japanese in Davao," Comment, Third Quarter, 1958, 23-26; and "The Japanese Way of Life in Prewar Davao," Philippine Studies, Vol. 7, No. 2, April, 1959, $172-186$.

3. A few of these planters were Spanish hacenderos, but the majority were American veterans who had taken their discharges in the Philippines and had been encouraged to settle at Davao by General Leonard Wood, who was at that time military governor responsible for most of Mindanao.

4. Neither locally recruited indigenous tribesmen nor Filipinos imported from the Visayas had proved to be efficient or reliable.

5. There is some confusion as to the exact number in this earliest group. Generoso P. Provido, "Japanese Interests in the Philippines" (Unpub. Ph.D. diss., Stanford University, 1936), 65, gives the figure as "about 100." Serafin D. Quiason, "The Japanese Colony in Davao, 1904-1941," Philippine Social Sciences and Humanities Review, XXIII, 2-4 (1958), 217, uses the phrase "some 150.” Gov. Gen. Theodore Roosevelt Jr.'s letter of October 12, 1932, specifies "100 laborers." (National Archives, Bureau of Insular Affairs, 6144/171-1/2; hereafter "BIA" plus file number.) Cody in "The Consolidation of the Japanese in Davao," op. cit., 26, puts the number at 180 in September, 1904, 100 more in January, 1905, and an additional 70 in July, 1905. In November, 1907, Governor Allen Walker estimated the number of Japanese in the District of Davao, Moro Province at "between 250 and 300." (BIA 6144/4.)

6. Davao in 1905 was little more than a village, typical of many scattered at wide intervals along the Mindanao coast.

7. BIA $6144 / 4$.

8. BIA $6144 / 171-1 / 2$. Enacted by the Philippine Commission on October 7, 1903.

9. Recent evidence supports the view that the Ohta Development Company was largely a one-man operation organized in corporate form mainly to comply with Philippine law. Cody, "The Consolidation of the Japanese in Davao," op. cit., 35.

10. BIA $6144 / 4$.

11. Cody, op. cit., 29.

12. BIA $6144 / 56-\mathrm{B}$.

13. Joseph R. Hayden, The Philippines (New York: Macmillan, 1955), 717. Furukawa Yoshizo in his Dabao Kaitakuki (Record of the development of Davao), Tokyo, 1956, gives the figure 7,000 as of 1919. (Quoted in Cody, op. cit., 36).

14. Report of Teopisto Guingona, Acting Gov. of Dept. of Mindanao and Sulu. BIA $6144 / 74$.

15. Ibid.

16. The Commonwealth Constitution effective Nov. 15, 1935, provided that only persons qualified to acquire lands in the public domain, i.e., Americans or Filipinos, could acquire private agricultural lands.

17. "By the end of 1919 the Ohta Development Company, in addition to its declared holdings of 1015 hectares, operated at least thirteen other land companies." Cody, op. cit., 35 .

18. "Japanese men have 'married' native women who can lawfully acquire land for them. When their holdings are improved, they send for their Japanese wives in the old country. The native 'wives' disappear, die or become servants to the ladies from Nippon." (Maj. William H. Anderson, The Philippine Problem (New York: G. P. Putnam's Sons, 1939), 280.) Japanese males cohabiting with aboriginal women did not legally marry them because once a native female married a Japanese she automatically lost her Philippine citizenship and thereby lost her right to acquire public lands by purchase or lease. The method generally used was for the Filipino woman to apply for public land by representing herself as unmarried while her Japanese "husband" arranged for the capital and labor required to develop the land. Thus, the title was clearly the woman's, and legality was sustained.

19. Act No. 2874 became effective November 29, 1919. In 1918 a similar proposal to restrict land purchases by aliens had been shelved because of the desire on the part of the United States not to offend its wartime ally Japan and because of a Japanese protest 
that such a restriction would violate Article I of the American-Japanese commercial treaty. However, the prospering Japanese business community at Davao enjoying the wartime boom in hemp sales publicized its economic success through conspicuous consumption and pressures for restrictive legislation increased accordingly.

20. The usual fee was $10 \%$ of the yearly yield.

21. Provido, op. cit., 70 .

22. On March 4, 1920, the Philippine Legislature in Act No. 2921 had passed legislation which made it clear that the Land Act of 1919 would not be effective retroactively and thus would permit Ohta, Furukawa, et al. to continue to hold lands already in their possession. However, since Act No. 2921 authorized the Secretary of Agriculture and Natural Resources to continue giving due course only to those applications filed before February 8, 1918, under pressure from Japanese interests the legislature passed a follow-up law, Act No. 2975 effective February 21, 1921, which authorized the Secretary of Agriculture and Natural Resources to give full consideration to applications filed under Act. No. 926 if filed before November 29, 1919.

23. P. P. Paguio, "Who is to blame about Davao?" China Weekly Review, LII (March, 1931), 39, quoted in Quiason, op. cit., 221.

24. BIA 22639-A/56-A.

25. As a result of this economic setback, for the first time the Japanese government was asked by the Davao community for assistance. It was the semi-official Bank of Taiwan which provided funds to sustain the abaca planters until the recovery of the market in 1923. (BIA 28876.)

26. After 1923, the management of the plantations at Davao was increasingly made up of university trained personnel newly arrived from Japan, and the former managers were relegated to the background.

27. Japan, Ministry of Foreign Affairs (hereafter "JMFA" plus file number, date and classification, if given) 1.6.2.1-6, Vol. 4, Feb. 16, 1924. Secret.

28. JMFA 1.6.2.1-6, Vol. 4, June 7, 1925. Secret.

29. Ibid.

30. Ibid.

31. JMFA J.1.2.0.J2-5, April 23, 1930.

32. JMFA 1.6.2.1-6, Vol. 4, Sept. 3, 1925. Secret.

33. JMFA A.6.3.0.1-5, Feb. 20, 1929. Secret.

34. N. V. Pacifico, Davao Directory (Davao, 1934), 82.

35. For example, a dispatch from the Chief, Consular Annex, Davao to the Consul General, Manila noted: "I spoke intimately with several leaders of the Bagobo, and I explained the position of the Japanese and thanked them for their long standing good will toward the Japanese." (JMFA 1.6.2.1-6, Vol. 4, Feb. 16, 1924. Secret.)

36. Tribune, Sept. 19, 1929.

37. Report of Secretary of Agriculture and Natural Resources Rafael S. Alunan to Governor General Dwight F. Davis.

38. Ibid.

39. Herald, May 24, 1930.

40. Tribune, May 27,1930 .

41. Bulletin, May 26, 1930.

42. Herald, May 26, 1930. In the same statement Rep. Vamenta also said that the pakiaw system had developed because of the failure of Filipino landholders to get needed capital from the Philippine National Bank while the Japanese on the other hand gave "square treatment" to the same Filipinos.

43. Both Vamenta and Aldanese were consistently identified in Japanese consular reports as pro-Japanese.

44. Herald, June 9, 1930.

45. JMFA J.1.2.0.J2-5, May 28, 1930. Secret.

46. JMFA J.1.2.0.J2-5, May 13, 1931. Secret.

47. Ibid.

48. Ibid.

49. Ibid.

50. Papers of Manuel Quezon, National Library, Manila, Aug. 14, 1930; hereafter "QP" plus date.

51. Speech of Welcome by Representative Arsenio Bonifacio on the Occasion of the Visit of the Japanese Delegation, Members of the Japanese Diet, to the Legislature on August 20, 1930.

52. Ibid.

53. JMFA K.2.1.0.4-1, Sept. 20, 1930. 
54. Philippines Free Press, Oct. 18, 1930.

55. JMFA A.6.3.0.1-5, Oct. 23, 1930.

56. Ibid.

57. Ibid.

58. New York Times, February 11, 1931.

59. Ibid.

60. Bureau of Customs, Customs Administrative Order No. 284, February 24, 1932.

61. Consul General Kimura was assured that the limitation on ports of entry for immigrants was aimed at the Chinese. This assurance came from Secretary of Justice Jose Abad Santos, Acting Insular Collector of Customs Guillermo Gomez and former Secretary of Finance Miguel Unson, all of whom Kimura described as having a "very good attitude toward the Japanese." (JMFA J.1.1.0.X1-U1, Feb. 9, 1932.) In reality both Chinese and Japanese immigration to Davao had decreased considerably in the preceding three years. For the previous three years, Japanese immigration to Davao was as follows: 1929-2,385, 1930-1,995, 1931-672; Chinese immigration for the same period was 1929-9,220, 1930-8,143, 1931-5,300. (Herald, March 7, 1932.)

62. Quoted in BIA 6144/After 165.

63. Ibid.

64. Ibid.

65. Ibid.

66. Ibid. For example, in an interview with the Spanish language newspaper $L a$ Opinion published on Jan. 20, 1932, Senator Benigno S. Aquino (later to be one of the most vigorous supporters of Japan's wartime occupation regime), then President Pro Tem of the Philippine Senate, ridiculed those who called Davao a "grave" problem and went on to excuse Japan's invasion of Manchuria by saying, "I see in the attitude of Japan nothing more than the desire to protect her rights which the Chinese government has not been able to guarantee." Quoted in BIA W6144/139.

67. BIA 6144/169.

68. Ibid.

69. Ibid.

70. In part as a result of the renewed controversy stimulated by the words and deeds of Acting Governor General Butte, Consul General Kimura made an inspection tour to Davao in March, 1932, and in the Sunday Tribune of March 13 the results of his visit were reported:

Consul Kimura was pleased to find the Japanese in Davao happy and contented although they complain of the low prices of hemp. . . The consul believes that the presence of the Japanese in Davao will not constitute a menace to the present friendly relations between the Philippines and Japan. . . . Regarding the closing of Davao as a port of entry for immigrants Consul Kimura told the Japanese there that the restrictions only apply to Chinese aliens and not to Japanese.

71. Newly appointed Governor General Theodore Roosevelt, Jr. revoked the order on the grounds that it violated existing United States treaties governing passports. (BIA With 364-A-873.)

72. JMFA S10.1.1.0-19, Reel 460, May 10, 1932. Secret.

73. Ibid.

74. Ibid.

75. Ibid.

76. For example, Jorge B. Vargas, then Assistant Secretary of the Department of Agriculture and Natural Resources, stated that the land owned by the Japanese had been acquired under the earlier public land law which contained no prohibition of the sale of public land to alien corporations. (Tribune, May 27, 1932.)

77. The conclusion of the Legislature as expressed through the Joint Resolution paralleled closely the views of most of the responsible local leaders in Davao. For example, the editor of the English language Davao Advocate stated that the truth about the Davao "menace" was that the biggest menace was in fact the defective land laws and corporation laws, whose language had permitted the Japanese to operate as they had. The Japanese, he said, have only profited by the errors of the Philippine Commission and of the Philippine Legislature and by the leasing and subleasing of lands by "respectable citizens." (Free Press, April 30, 1932, 7.)

78. BIA 28876 Jan. 1, 1935, 7.

79. Ibid.

80. JMFA J.1.2.0.J2-5, June 6, 1932. Secret.

81. BIA 28876, Jan. 1, 1935, 9. 
82. BIA $6144 / 171-1 / 2$. Letter dated Oct. 12, 1932.

83. Ibid.

84. Herald, Oct. 25, 1933. An interesting parallel to the Davao situation is reported concerning land and aliens with reference to the Fiji Islands in the New York Times for July 29, 1962:

Most land is vested in Fijian ownership, so that many an easygoing Fijian is landlord to a more energetic Indian [immigrant] farmer. Fijians repeatedly complain of lack of capital for land development, the Indians of lack of land leases.

85. Bulletin, Jan. 3, 1934

86. JMFA S10.1.1.0-19, Reel 460, Nov. 21, 1933. Secret.

87. JMFA S10.1.1.0-19, Reel 460, Dec. 12, 1933. Secret.

88. JMFA S10.1.1.0-19, Reel 460, Jan. 4, 1933. Secret.

89. JMFA K.2.1.0.4-1, June 30, 1933.

90. BIA 26712/11.

91. Just under half of these were women and children.

92. BIA 28876 Jan. 1, 1935, 11.

93. JMFA S10.1.1.0-19, Reel 459, July 26, 1934.

94. Herald, Sept. 27, 1934. In an interpolation from the Convention floor Delegate Tomas Confesor agreed with Pelayo that Filipinos were principally to blame for the Davao situation, but he stressed the economic prosperity of the province and suggested that if the Convention took any action which would force the Japanese to give up their lands (as was recommended by Pelayo) there might be an economic collapse which would work a far more severe hardship on the Filipinos dependent on the Japanese for their income than it would on the Japanese themselves. Delegate Hilario Moncado interpolated that the Japanese invasion of Manchuria was being repeated in Davao. At this point Convention President Claro Recto stated that it was difficult for the Constitutional Convention to discuss this kind of problem and adjourned the session.

95. Article XII of the Philippine Constitution reads as follows:

SECTION 1. All agricultural, timber, and mineral lands of the public domain, waters, minerals, coal, petroleum, and other mineral oils, all forces of potential energy, and other natural resources of the Philippines belong to the State, and their disposition, exploitation, development or utilization shall be limited to citizens of the Philippines, or to corporations or associations at least sixty per centum of the capital of which is owned by such citizens, subject to any existing right, grant, lease, or concession at the time of the inauguration of the Government established under this Constitution. Natural resources, with the exception of public agricultural land, shall not be alienated, and no license, concession, or lease for the exploitation, development, or utilization of any of the natural resources shall be granted for a period exceeding twenty-five years, renewable for another twenty-five years, except as to water rights for irrigation, water supply, fisheries, or industrial uses other than the development of water power, in which cases beneficial use may be the measure and the limit of the grant.

SECTION 2. No private corporation or association may acquire, lease, or hold public agricultural lands in excess of one thousand and twenty-four hectares, nor may any individual acquire such lands by purchase in excess of one hundred and forty-four hectares, or by lease in excess of one thousand and twenty-four hectares, or by homestead in excess of twenty-four hectares. Lands adapted to grazing, not exceeding two thousand hectares, may be leased to an individual, private corporation, or association.

Section 3. The National Assembly may determine by law the size of private agricultural land which individuals, corporations, or associations may acquire and hold, subject to rights existing prior to the enactment of such law.

Section 4. The National Assembly may authorize, upon payment of just compensation, the expropriation of lands to be subdivided into small lots and conveyed at cost to individuals.

SECTION 5. Save in cases of hereditary succession, no private agricultural land shall be transferred or assigned except to individuals, corporations, or associations qualified to acquire or hold lands of the public domain in the Philippines.

SEction 6. The State may, in the interest of national welfare and defense, establish and operate industries and means of transportation and communication, and, upon payment of just compensation, transfer to public ownership utilities and other private enterprises to be operated by the Government. 
96. The material in the paragraphs on Pelayo that follow is all taken from JMFA S10.1.1.0-19, Reel 460, Oct. 23, 1934. Secret.

97. For a detailed account of the motives and maneuvers of Quezon in leading the successful struggle in the Philippines to kill the Hare-Hawes-Cutting Act, which would have made the Islands independent in 1946, see Theodore Friend, "The Philippine Sugar Industry and the Politics of Independence, 1929-1935," Journal of Asian Studies, XXII, No. 2, Feb., 1963, 179-192.

98. The material in the paragraphs on countermeasures that follow is all taken from JMFA S10.1.1.0-19, Reel 460, Oct. 26, 1934. Secret.

99. Herald, Jan. 4, 1935.

100. Herald, Feb. 5, 1935.

101. What was probably a much more realistic estimate was published in the Philippine-Japan Yearbook and Business Directory for 1938, in which it was estimated that Japanese corporations and Japanese farm contractors in Davao employed in the neighborhood of 21,000 Filipino laborers. Davao wage rates were as high as any in the Islands, and Japanese employers offered their workers free medical care, hospitalization, paid sick leaves, Christmas bonuses, free transportation, excellent living quarters and recreational facilities at company expense. The annual Filipino labor payroll at Davao was about seven million pesos. Monthly wages were broken down as follows:

\begin{tabular}{|c|c|c|}
\hline Source of Employment & Laborers & Wages (Monthly \\
\hline Abaca Plantations ..... & .. 7,000 & P $245,000.00$ \\
\hline Lumber-yards and sawmills & 1,500 & $45,000.00$ \\
\hline Baling establishments ............ & 2,500 & $70,000.00$ \\
\hline Other sources & 10,000 & $210,000.00$ \\
\hline Total & $.21,000$ & P $570,000.00$ \\
\hline
\end{tabular}

(Ichiro Shibata, "Japanese Contribution to Davao's Development and Progress," Philippine-Japan Yearbook and Business Directory 1938 (Manila: M. Farolan, 1938), 333.)

102. The other 2000, according to Kaneko, had died of one sickness or another.

103. "Two Thousand Japanese Killed By Outlaws in Davao," Philippine Magazine, April, 1935, 180.

104. Ibid.

105. "The leases and subleases to the Japanese of lands covered by public lands applications have been voluntarily executed by the Filipinos of Davao, and the documents connected therewith have been drafted and prepared upon the advice of local attorneys who must have given them assurances of the validity of the transactions. With the leases and subleases, the Filipinos expect that after a certain period, they will be the owners of productive and rich fields of abaca and coconut plantations without having invested money for the clearing and cultivation of the land. If, however, the government should push through its investigation of conditions in Davao, the illegality of the Japanese transactions would be unearthed, and their dreams of becoming big landholders and property owners would be shattered. This accounts for the preconcerted action on the part of the Filipino public land applicants and the Japanese in Davao to conceal the facts and prevent government representatives from securing important data." (Aproniano C. Borres, "Can We Redeem Davao?" The Commonwealth Advocate, May, 1935.)

106. Herald, Feb. 11, 1935.

107. Ibid.

108. Ibid.

109. JMFA S10.1.1.0-19, Reel 460, Feb. 18, 1935.

110. JMFA S10.1.1.0-19, Reel 460, Feb. 11, 1935. According to the Bulletin of Feb. 9, Consul Kaneko had warned that if Secretary Rodriguez carried out any drastic changes in the pattern of Japanese landholdings, there would be "serious consequences." The Tribune of the same date reported Kaneko as saying that if any subleases of Japanese were canceled, the Japanese would immediately press a civil suit in the courts and would fight to the end.

111. Sada Kojiro, ed. and compiler, Hirippin (Philippines) (Tokyo: Toa Keizai Chosakyoku, 1939), 190.

112. JMFA S10.1.1.0-19, Reel 460, Feb. 19, 1935.

113. Ibid. It was also agreed not to call the round table conference which Consul Kaneko had earlier proposed to Rodriguez in Davao. Both men felt that in the present circumstances such a conference could only inflame passions.

114. Ibid. 
115. The entire report is contained in BIA 6144, Feb. 19, 1935.

116. About $50 \%$ of the total Japanese holdings were affected.

117. See supra Footnote 22.

118. Herald, March 8, 1935. Interestingly, at almost the same moment the Filipino delegation en route to the United States to present to President Roosevelt the draft of the Constitution for the Commonwealth of the Philippines made a brief stopover in Tokyo, and Rafael Alunan, Rodriguez's predecessor as Secretary of Agriculture and Commerce, assured the Japanese press that the Davao land question would soon be settled amicably. (Herald, March 11, 1935.)

119. Tribune, April 9, 1935.

120. Ibid.

121. JMFA K.2.1.0.5-1, March 7, 1935. The party included the following persons, all of Davao:

\begin{tabular}{|c|c|c|}
\hline NAME & AGE & OCCUPATION \\
\hline Antonio Habana, Jr. & 33 & Lawyer \\
\hline Arsenio Suazo .............. & $\ldots .45$ & Lawyer \\
\hline Leon Garcia .............. & $\ldots 37$ & Lawyer \\
\hline Manuel Zabat .. & $\ldots 40$ & Engineer \\
\hline 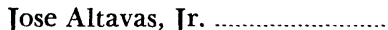 & $\ldots 34$ & Captain, Merchant Marine \\
\hline Vicente Guinoo & $\ldots .40$ & Businessman \\
\hline 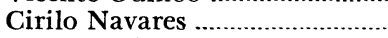 & $\ldots .35$ & Internal Revenue Agent \\
\hline Dr. Jose Ebro & $\ldots . .41$ & Physician \\
\hline Mrs. M. R. Ebro & $\ldots .35$ & Proprietress \\
\hline Mrs. Vicenta M. Vda. Tiongko & 46 & Proprietress \\
\hline Miss Josefa M. Tiongko ............... & $\ldots 11$ & Student \\
\hline 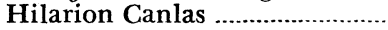 & $\ldots 33$ & Businessman \\
\hline Mrs. Luis C. Canlas ... & $\ldots 60$ & Proprietress \\
\hline Miss Cornelia Canlas ................. & $\ldots .35$ & Proprietress \\
\hline Miss Solita Habana .......... & $\ldots . .12$ & Student \\
\hline
\end{tabular}

122. Ibid.

123. Ibid. That the trip must have been an unqualified success seems evident from a letter addressed after his return to Davao by the tour leader Antonio Habana, Jr. to Tashiro Shigenori, Information Bureau, Ministry of Foreign Affairs, Tokyo. Wrote Habana:

The members of the Davao Goodwill Party are well impressed of the greatness of Japan, particularly her tremendous progress along industrial lines. During our brief sojourn there we have grown to admire your people who have shown to be capable, self-disciplined, courteous, honest and reliable. These sterling qualities supported by their patriotic ardor undoubtedly have contributed largely in the development of Japan. I fervently hope that their example will be followed by other Oriental peoples. You can rest assured that as far as the members of our Party are concerned we shall endeavor to foster closer and stronger relations between the Filipinos and Japanese. Personally I am of the opinion that if my Country desires to be on the same level with other powerful Nations, as it is her wish to be, there is no other country from which she should copy than Japan. We have many characteristics similar to each other and added to it the geographical proximity. Thus it is only a matter of time with the help and cooperation of those intelligent elements (Japanese and Filipinos) who have had on previous occasions the opportunity to know each other thru social and business contact when reapprochement can be (Ibid.) brought about.

124. JMFA S10.1.1.0-19, Reel 459, March 26, 1935. Secret.

125. Ibid.

126. Ibid.

127. Ibid. The Foreign Office sent Consul General Kimura a special appropriation of 400 pesos to cover Farolan's expenses. (JMFA S10.1.1.0-19, Reel 459, April 17, 1935.) The subtle power of the monetary value of Japanese advertising also seemed evident in a new publication, a magazine called The Critic, which began appearing in 1935 and carried editorials critical of Secretary Rodriguez and of what the magazine called "fear propaganda" about the "Japanese menace." On the contrary, argued The Critic, the Japanese colony at Davao had brought flawless economic organization, excellent social conditions, and a high level of prosperity to the region. And instead of the then current 
attitude, which was described as one of "hysteria and hatred," the magazine wrote that Filipinos would be well advised to view the Japanese settlement at Davao as "a laboratory of progressive and scientific colonizing and farming." (See "The Davao Land Problem," The Critic, Vol. 1, No. 9, March 23, 1935, 8.)

128. JMFA S10.1.1.0-19, Reel 459, May 22, 1935. The paragraphs concerning the visit of Farolan to Davao are all derived from this same source.

129. El Debate (Spanish), Mabuhay (Tagalog), Herald (English), Monday Mail (English).

130. Consul Kaneko also made use of Farolan's presence in Davao to have him address the Davao Goodwill Tourist Party, which was about to depart for Japan. Farolan gave the group a glowing account of the impressions of Japan which he had received on his visit there the preceding year. In addition to praising the Japanese national character, he pointed out how much Filipinos could learn from the Japanese, gave a number of travel tips, and distributed copies of his book Japan At a Glance. Kaneko was so pleased by Farolan's performance on this occasion that he wrote that Farolan had "adroitly given evidence of a pro-Japanese gesture." (Ibid.)

131. Quoted in M. Farolan, The Davao Problem (Manila: M. Farolan, 1935), 22.

132. Herald, June 10, 1935.

133. Provido, op. cit., 79.

134. JMFA S10.1.1.1-19, Reel 460, Nov. 10, 1935.

135. The Herald gave the figure 187 as of Oct. 1. (Herald, Oct. 2, 1935.)

136. The significance of the role of wives and relatives can not be overestimated. For example, Christian Filipino surveyors in the employ of the Bureau of Lands would pay a Bagobo or Mandayan tribesman one peso to affix his thumbprint to a document which purported to show that he had been paid several hundred pesos for a sizable tract (50 or 100 hectares) of land. Since it was illegal for government surveyors to acquire public lands, the documentation would necessarily be in the name of the surveyor's wife or relatives. The land so secured would then be subleased to the Japanese. (Soriano, op. cit., 83).

137. Lorenzo, as noted earlier, was himself a consulting attorney in the employ of the Japanese.

138. Reproduced in Antonio Marquez, "A Letter from Davao," The Commonwealth Advocate, July, 1941. Davao Justice of the Peace Manuel P. Castro, one of those affected by Secretary Rodriguez's orders, made public a letter to the Secretary in which he admitted that he and his wife had two free patents on two pieces of public land in Davao and that they had contracted Japanese laborers to plant coconuts and to work the land. Wrote Castro:

The reason is simple. The Japanese are hardworking people, they know how to work and they know how to comply with their contracts. They are good peaceful people, economical and thrifty. They know the value of time, health and sanitation. We are satisfied with their work and what they have accomplished in three months cannot be accomplished by Filipino laborers in three years.

As a Filipino I do not want an inch of our lands to be permanently owned by Japanese, especially the ones we applied for, but the Japanese as laborers we have nothing but admiration for them. (Tribune, July 16, 1935.)

139. JMFA S10.1.1.0-19, Reel 460, July through Sept., 1935.

140. JMFA S10.1.1.0-19, Reel 460, July 13, 1935.

141. Ibid.

142. JMFA S10.1.1.0-19, Reel 460, Nov. 10, 1935.

143. JMFA S10.1.1.0-19, Reel 460, Sept. 9, 1935.

144. Ibid.

145. Where not otherwise footnoted, the chronology which follows is taken from BIA 6144, April 2, 1936, "The Davao Land Question," Confidential from Henry B. Day, American Vice Consul, American Consulate, Manila.

146. Repeatedly Filipino officials attempted to convince the Japanese that it was not they who were at fault in the land question but rather native Filipinos who had obtained public lands under false pretenses. President Quezon himself was to give voice to this view when at one of his press conferences the following exchange took place:

THE PRESS: What is your attitude, Mr. President, toward the question of the Japanese sub-leasing in Davao?

THE PRESIDENT: That law does not permit it. 
THE PRESS: Any move to cancel these leases that have been granted?

THE PRESIDENT: There seems to be no evidence there is a sub-lease.

There is evidence that these Japanese that are working there are working for the account of the Filipinos who have leased the land.

(QP. Transcript of Presidential Press Conference at Malacanang, Dec. 16, 1936.)

147. JMFA K.2.1.0.4-1, Oct. 8, 1935. (Statement referred to underlined in red.) On the same date in a press interview Furukawa Yoshizo of the Furukawa Plantation Co. blamed the whole crisis on the Manila newspapers, which, he said, were looking for a circulation booster. (Herald, Oct. 1, 1935.)

148. Willard Price, "Japan in the Philippines," Harper's, May, 1936, 611.

149. Though the Japanese numbered less than $10 \%$ of the population of the province of Davao, they paid between 50 and $70 \%$ of the taxes. For example, a statistical survey of the taxes paid by the Japanese in 1935 showed:
a. Lease rent
P 20,000.00
b. Real property tax
$80,000.00$
c. Sales tax
$300,000.00$
d. Income tax
$20,000.00$
e. Cedula or personal registration tax
$8,000.00$
f. License $\operatorname{tax}$
$22,000.00$
g. Customs tax $371,300.00$
$\mathbf{P} 821,300.00$

(BIA 26712/18.)

150. E. De Guzman, "DAVAO WHAT ABOUT IT?” Union, Oct. 7, 1935.

151. Tribune, Oct. $18,1935$.

152. Bulletin, Nov. 9, 1935.

153. Bulletin, Nov. $11,1935$.

154. JMFA S10.1.1.0-19, Reel 461, Nov. 11, 1935.

155. New York Times, Nov. 19, 1935.

156. Ibid.

157. Secretary Rodriguez was quoted as having said, "Let the law take its natural course." (Tribune, Nov. 21, 1935.)

158. BIA 212/367. The members of the committee were Alfredo Fajardo, Nicanor A. Roxas and Teodosio Trinidad.

159. JMFA S10.1.1.0-19, Reel 461, Nov. 25, 1935.

160. On December 7th Quezon had personally informed Consul General Uchiyama that he had ordered an end to the cancellation of leases. (JMFA S10.1.1.0-19, Reel 461, Dec. 7, 1935.)

161. JMFA S10.1.1.0-19, Reel 461, Feb. 6, 1936

162. Ibid.

163. Ibid.

164. JMFA S10.1.1.0-19, Reel 461, Feb. 12, 1936.

165. Ibid.

166. Sabido's comments are found in JMFA S10.1.1.0-19, Reel 459, Feb. 26, 1936.

167. Ibid.

168. JMFA S10.1.1.0-19, Reel 460, Nov. 7, 1935.

169. Tribune, April 8, 1936.

170. JMFA S10.1.1.0-19, Reel 461, April 7, 1936.

171. Ibid.

172. Ibid.

173. Tribune, April 9, 1936.

174. Tribune, April 11, 1936.

175. Tribune, April 15, 1936.

176. QP. Transcript of Presidential Press Conference at Malacanang, May 8, 1936.

177. JMFA A.6.0.0.1-33, May 9, 1936. In this same dispatch Uchiyama wrote the Foreign Office: "Since we want Murphy to work for an enlightened public opinion in the United States after his return home, I said that I wanted Murphy to stop in Japan and meet the Prime Minister and the Foreign Minister in order to hear their explanations of Japan's peaceful policies and then on returning home to work to resolve misunderstandings about the Philippine problem."

178. JMFA S10.1.1.0-19, Reel 461, May 13, 1936.

179. JMFA S10.1.1.0-19, Reel 461, June 18, 1936.

180. BIA $17073 / 456$.

181. Added credence was given to the legend of this attributed phrase by virtue of a statement of Quezon's longtime personal secretary Jorge B. Vargas who during the 
World War II Japanese occupation of the Philippines once again quoted the Commonwealth President as having uttered these exact words. (Tribune, Dec. 13, 1942.)

182. Quoted in "There is a Davao Problem," Philippine Magazine, July, 1936.

183. Director of Prisons Paulino Santos, who had accompanied Quezon on his trip to Davao and was former Chief of Staff of the Philippine Army, was appointed by the President as manager of the National Land Settlement Administration, and young army reservists were given preference over other applicants for settlement in Mindanao because it was planned to distribute young men with military training in strategic locations in order to try to neutralize the Japanese in Davao, many of whom were reported to be Japanese Army or Navy reservists.

184. Informed and observant Filipinos in Davao, on the other hand, developed a great deal of admiration for many of the qualities which the Japanese community in their midst seemed to demonstrate: industriousness, cooperation, thrift, obedience to law.

185. Cody, “The Japanese Way of Life in Prewar Davao," op. cit., 180.

186. A specific example of the relationship between concern over Davao and worsening of the international situation is to be seen immediately following the bombing of the United States gunboat Panay. In an editorial entitled "Time to Tackle the Davao Problem" in its edition for January 8, 1938, the Herald wrote: "We welcome Japanese immigration and capital but we do not desire that they be so domiciled and concentrated that they are possible sources of trouble. To this proposition, even Japan itself should have no objection."

187. JMFA G.3.1.0.1, July 16, 1936.

188. JMFA A.6.0.0.1-33-1, Sept. 23, 1936.

189. JMFA A.6.0.0.1-33, Jan. 16, 1937.

190. Ibid.

191. Ibid.

192. JMFA S10.1.1.0-19, Reel 459, April 23, 1937.

193. JMFA S10.1.1.0-19, Reel 459, Aug. 4, 1937.

194. Ibid.

195. Ibid.

196. United States authorities returned to the Philippine Government proceeds from the revenue tax on tobacco and cigars and from the processing tax on sugar.

197. In January, 1938, Japanese diplomats in Washington had made approaches to the State Department about Davao but had been told that the land question did not properly fall within the realm of foreign relations and that therefore its solution would be left in the hands of the Commonwealth Government. (JMFA S10.1.1.0-19, Reel 461, Jan. 18, 1938.)

198. General Burnett had served in Japan for many years as a military attache at the United States Embassy in Tokyo, and he both spoke and read the Japanese language. When General Burnett died in February of 1940, he left behind a request that at his funeral the catafalque be covered with the Japanese as well as the American flag and that his ashes be interred in Japan.

199. BIA 26712/14.

200. BIA 26712/15.

201. During his stay in the Philippines, General Burnett had held a conference with Acting Consul General Kihara in regard to the Davao problem. (JMFA A.6.0.0.14, Political Diary, Oct. 27, 1938.) And on his trip to Davao General Burnett was accompanied by Lieutenant Jose S. Laurel III, who had been appointed an aide to President Quezon after his return from Japan, where he had graduated from the Imperial Military Academy. (Tribune, Nov. 3, 1938.) Lieutenant Laurel, the son of Jose P. Laurel, maintained liaison with the Japanese consulates both in Manila and Davao. (JMFA A.6.0.0.1-33, Aug. 25, 1938.)

202. The Japanese position at Davao had been given strong support by a memorandum entitled "Japanese Contributions to the Development of Davao," submitted to General Burnett by F. Ohmori, Director, Ohta Development Company, in a letter dated Nov. 7, 1938 (BIA 26712/18). Mr. Ohmori discussed the construction and maintenance by the Japanese of private roads open to the public without charge, the Agricultural Experiment Station established by the Ohta company April 1, 1929, and its cultivation on an experimental basis of cotton, ramie, derris (a leguminous plant the roots of which contain rotenone and are used as an insecticide), coffee, cacao, citrus fruits, etc., the invention and utilization of a hemp stripping machine, and the Japanese hospital opened by Mr. Ohta in 1918 and available to all. Ohmori recorded the number of Japanese residents in the City and Province of Davao as of 1937 as follows: 


a. Agriculture
b. Employees and Clerks
c. Manufacturing
d. Fisheries
e. Merchants
f. Lumbering and Sawmills
g. All others

A survey made by the Institute of Pacific Relations at approximately the same time concluded that the number of Japanese in the Islands was small and that they did not yet pose either a political or economic threat. President Quezon was again quoted as having supposedly said that "no Davao problem exists." The report pointed out that the provisions of the Constitution safeguarding the nation's natural resources were at least for the time being sufficient protection against any alien takeover. (Herald, Nov. 1, 1938.)

203. JMFA A.6.0.0.1-33, Nov. 22, 1938.

204. JMFA A.6.0.0.1-33, Nov. 29, 1938.

205. JMFA S10.1.1.0-19, Reel 461, Mar. 4, 1939.

206. BIA 6144/264.

207. Herald, March 4, 1939. As an answer to those renewed suggestions that Davao be closed as a port of entry, Assemblyman Augustin Kintanar, Chairman of the Committee on Navigation, proposed that the City of Davao be declared a port of entry by law since its status as a port of entry was dependent upon an executive order of the then Governor General Leonard Wood signed on Dec. 15, 1925. (Bulletin, Mar. 9, 1939.)

208. Herald, March 30, 1939.

209. Ibid.

210. JMFA J.1.2.0.J2-5, April 3, 1939.

211. Ibid.

212. Ibid.

213. Congressional Record, May 19, 1939, 5826-7.

214. Letter to the author from John G. Alexander, July 19, 1962.

215. Herald, May 22, 1939. Exactly what Congressman Alexander was really up to in 1939 is not too clear, despite what he now says, when one examines his speeches in the Congressional Record. Whether he thought that an investigation of pro-Japanese activities in the Philippines would support the retentionist or reexaminationist position of High Commissioner McNutt, for whom Mr. Alexander had the greatest praise, or whether he thought such an inquiry would convince Congress to get rid of the Islands at once and not wait until 1946, cannot easily be determined from a study of his remarks. He claimed on the one hand that the United States could not afford to let slip from its grasp into Japanese hands investments in the Philippines, which, he said, amounted to $\$ 840,000,000$ over a 40 -year period, or $\$ 45,000,000$ in United Statesguaranteed Philippine government bonds, or an annual Philippine-American trade of $\$ 200,000,000$. On the other hand, he argued that the United States ought to disengage itself from the Philippines at once:

There is a great mass of good argument for immediate withdrawal from our overlordship of the Islands. It is said that 95 percent of our people are for such a thing. This is undoubtedly the case-not alone because of their desire to protect and promote peace, but also because of the competition which the Islands give our industry, commerce and agriculture because of our arrangement letting their products in here duty-free. Two very important items which especially affect the welfare of my own region are sugar and hemp products, such as rope and binder twine. Our Minnesota rope and twine factory is, like all others in the country, operating about $50 \%$ of capacity because of this heavy foreign competition, and is also operating at heavy annual losses. When these factories have been completely routed and put out of business because of this duty-free cheap, oriental labor competition, then the international Rope and Binder Twine Trust, having a complete monopoly, can double the price to suit themselves and make up for present losses, thus taking another slice from our farmers' already meager income from wheat, barley, oats, rye and such important small grains. Japanese 
farmers in the Philippines' richest province, Davao, now grow and sell most of the world's best hemp. (Congressional Record, May 23, 1939, 5034.)

216. Letter from John G. Alexander, op. cit.

217. JMFA S10.1.1.0-19, Reel 459, May 22, 1939.

218. Ibid.

219. Ibid. Kihara quoted President Quezon as saying to him: "The Alexander resolution is utterly ridiculous. Though, as you have said, this must be a Communist maneuver, it must be presented with the backstage connivance of selfish Filipinos and anti-independence Americans." (JMFA J.1.1.0.X1-U1, June 2, 1939.)

220. Herald, May 22, 1939.

221. Congressional Record, July 6, 1939, 3084. It was undoubtedly this kind of statement that had led Acting Consul General Kihara to charge that the Alexander Resolution was Communist-instigated.

222. Union, June 1, 1939.

223. Congressional Record, May 23, 1939, 6032.

224. Newspaper clipping found in QP. Dated June 8, 1939.

225. Congressional Record, June 12, 1939, 7055-6.

226. QP. June 28, 1939.

227. Herald, June 29, 1939

228. Quoted in G. H. Enosawa, Manuel L. Quezon from Nipa Hut to Malacanan (Tokyo: Japan Publicity Agency, 1940), 146-7.

229. In evaluating the election results for the Foreign Ministry, Acting Consul General Kihara reported to Tokyo: "Our side lost four supporters: Quimpo lost in Davao; Aquino, Roxas and Osias retired. Newly elected were [Isidro] Vamenta and [Quintin] Paredes. Reelected were [Pedro] Sabido, [Tomas] Oppus, [Enrique] Magalona, [Guillermo Z.] Villanueva and [Pedro] Veyra whom we can continue to use. Sotto understands us rather well ...." (JMFA A.6.0.0.1-33-1, Nov. 14, 1938.)

230. JMFA J.1.2.0.J2-5, Sept. 3, 1939.

231. Ibid.

232. Ibid.

233. JMFA J.1.2.0.J2-5, Sept. 25, 1939

234. Ibid.

235. JMFA J.1.2.0.J2-5, Oct. 25, 1939.

236. Free Press, June 22, 1940, 33.

237. New York Times, July 6, 1940. On first hearing this report of the purported nature of Nomura's visit, High Commissioner Sayre said that he understood that the Japanese in Davao were "pretty healthy." (Ibid.)

238. Tribune, July 23, 1940.

239. Ibid.

240. JMFA A.6.0.0.1-33, Aug. 29, 1940.

241. The Tribune, Feb. 13, 1941 .

242. A. S. Gabila, “18,000 Japanese Can't Be Wrong,” Graphic, July 10, 1941, 12.

243. JMFA S10.1.1.0-19, Reel 461, Apr. 6, 1941.

244. JMFA S10.1.1.0-19, Reel 461, Sept. 19, 1941.

245. JMFA S10.1.1.0-19, Reel 461, Sept. 24, 1941.

246. The Quezon Papers for 1941 contain several personal letters from Morokuma,

Kihara, etc., inquiring about the health of the President, Mrs. Quezon's ramie plants, and the Quezon farm in Arayat. Vide, e.g., QP, June 6, 1941, and June 26, 1941.

247. JMFA S10.1.1.0-19, Reel 461, Dec. 2, 1941.

248. Teodoro M. Locsin, "Land of the Rising Sun Davaokuo," Free Press, Dec. 6, $1941,2$.

249. Interestingly the Japanese themselves had no respect for the very Filipinos whose services they found so indispensable. One official of the Furukawa Plantation Company said: "They are just like small children for they eat whatever kind of candy is given them." (Quoted in Rafaelita H. Soriano, "Japanese Occupation of the Philippines, With Special Reference to Japanese Propaganda, 1941-1945," Unpub. Ph.D. diss., University of Michigan, 1948, 85.)

250. A. Marquez, "A Letter from Davao," op. cit., 12.

251. Union, Sept. 1, 1941.

252. Son of Juan Sarenas.

253. Mrs. Concepcion Breva de Sarenas, wife of Juan Sarenas.

254. JMFA S10.1.1.0-19, Reel 461, July 7, 1941.

255. JMFA: A.6.0.0.1-33, Nov. 13, 1941 .

256. Ibid. 